UNIVERSIDADE DE SÃO PAULO

FACULDADE DE MEDICINA DE RIBEIRÃO PRETO

PROGRAMA DE PÓS-GRADUAÇÃO EM GENÉTICA

PEDRO PARANHOS TANAKA

Controle Pós-Transcricional do Gene Autoimmune Regulator (Aire) por meio do microRNA-155

Ribeirão Preto - SP

2019 


\title{
Controle Pós-Transcricional do Gene Autoimmune Regulator (Aire) por meio do microRNA-155
}

\begin{abstract}
Dissertação apresentada ao Programa de Pós-Graduação em Genética da Faculdade de Medicina de Ribeirão Preto, da Universidade de São Paulo, para obtenção do título de Mestre em Ciências. Versão corrigida. A versão original encontra-se disponível tanto na Biblioteca da Unidade que aloja o Programa, quanto na Biblioteca Digital de Teses e Dissertações da USP (BDTD).
\end{abstract}

Área de concentração: Genética

Orientador: Prof. Dr. Geraldo Aleixo da Silva Passos Júnior

Ribeirão Preto - SP 2019 
AUTORIZO A REPRODUÇÃO E DIVULGAÇÃO TOTAL OU PARCIAL DESTE TRABALHO, POR QUALQUER MEIO CONVENCIONAL OU ELETRÔNICO, PARA FINS DE ESTUDO E PESQUISA, DESDE QUE CITADA A FONTE.

\section{Catalogação da Publicação}

Tanaka, Pedro Paranhos

Controle Pós-transcricional do Gene Autoimmune Regulator (Aire) por meio do microRNA-155.

Ribeirão Preto, 2019

$100 \mathrm{p}$.

Dissertação de Mestrado, apresentada à Faculdade de Medicina de Ribeirão Preto da Universidade de São Paulo. Área de concentração: Genética

1. Células tímicas epiteliais medulares (mTECs). 2. Gene autoimmune regulator (Aire). 3. Controle pós-transcricional. 4. MicroRNA-155. 5. Transcriptoma. 


\section{APOIO E SUPORTE FINANCEIRO}

Este trabalho foi realizado no Laboratório de Imunogenética Molecular, localizado no Departamento de Genética da Faculdade de Medicina de Ribeirão Preto (FMRP), da Universidade de São Paulo (USP), com o apoio ou suporte financeiro das seguintes instituições:

- Fundação de Amparo à Pesquisa do Estado de São Paulo (FAPESP);

- Conselho Nacional de Desenvolvimento Científico e Tecnológico (CNPq);

- Coordenação de Aperfeiçoamento de Pessoal de Nível Superior (CAPES);

- Faculdade de Medicina de Ribeirão Preto - FMRP - USP 
Nome: TANAKA, Pedro Paranhos

Título: Controle Pós-Transcricional do Gene Autoimmune Regulator (Aire) por meio do microRNA-155

Dissertação apresentada ao Programa de Pós-graduação em Genética da Faculdade de Medicina de Ribeirão Preto, da Universidade de São Paulo, para obtenção do título de Mestre em Ciências.

Aprovada em:

\section{Banca Examinadora}

Prof. Dr.

Instituição:

Assinatura:

Prof. Dr. Instituição: Assinatura:

Prof. Dr. Instituição: Assinatura: 


\section{AGRADECIMENTOS}

Meus sinceros agradecimentos a todas as pessoas que colaboraram e participaram direta ou indiretamente da realização deste trabalho.

Agradeço minha família por todo o suporte e incentivo ao longo desses anos.

Agradeço meus amigos do Laboratório de Imunogenética Molecular por todo o apoio e ajuda.

Agradeço à Prof. Dra. Karina Fittipaldi Bombonato Prado e ao funcionário Roger Rodrigo Fernandes do Departamento de Biologia Básica e Oral da Faculdade de Odontologia de Ribeirão Preto, USP, pelo suporte durante a realização da técnica de imunofluorescência.

Agradeço ao Professor Geraldo A. Passos pela oportunidade que me foi dada e por todo os ensinamentos. 


\section{RESUMO}

Tanaka, Pedro Paranhos. Controle Pós-Transcricional do Gene Autoimmune Regulator (Aire) por meio do microRNA-155. 2019. Dissertação de Mestrado, Faculdade de Medicina de Ribeirão Preto, Universidade de São Paulo, Ribeirão Preto.

O timo é um órgão linfoide primário onde ocorre o estabelecimento da tolerância imunológica central pela eliminação de clones de linfócitos $T$ auto reativos. Precursores de linfócitos $T$ adentram o timo pela junção córtico-medular e são denominados de timócitos. Esses timócitos passam então por dois processos, a seleção positiva (que ocorre no córtex do timo e é mediada pelas células tímicas epiteliais corticais ou cTECs) e a seleção negativa (que ocorre na medula e é mediada pelas células tímicas epiteliais medulares ou mTECs). Durante a seleção positiva, somente os clones de timócitos duplo-positivos (DP) que expressam o receptor $T C R \alpha / \beta^{+}$funcional (que reconhece moléculas de $\mathrm{MHC})$ mais os marcadores $\mathrm{CD} 4 / \mathrm{CD} 8\left(\mathrm{TCRa} / \beta^{+}, \mathrm{CD} 4^{+}, \mathrm{CD} 8^{+}\right)$são exportados para a medula tímica onde ocorrerá a seleção negativa. Ela ocorrerá sobre os clones de timócitos simples positivos (SP) (TCR $\alpha / \beta^{+} \mathrm{CD} 4^{+}$ou TCR $\alpha / \beta^{+} \mathrm{CD} 8^{+}$). As células mTEC expressam uma grande variedade de antígenos restritos a tecidos (TRA) e os apresentam para os timócitos SP. Aqueles clones que reconhecem com alta avidez e afinidade algum desses autoantígenos são deletados por apoptose e isso acaba evitando auto agressividade imunológica periférica. A propriedade das mTECs de expressar uma gama diversa de autoantígenos foi denominada de expressão gênica promiscua (PGE) a qual abrange virtualmente todos os antígenos dos tecidos do organismo. O significado da PGE é essencialmente imunológico e isso garante a representação dos constituintes próprios na glândula do timo e consequentemente o estabelecimento da tolerância imunológica central. O principal controlador da PGE é o gene Autoimmune Regulator (Aire), que age como um fator de transcrição não convencional e promove a expressão de milhares de mRNAs de TRAS nas mTECs. Além disso, Aire também controla a expressão de RNAs não codificadores, como os microRNAs. Os microRNAs são pequenos RNAs de fita simples ( 22nt) que atuam no controle pós-transcricional através da degradação do mRNA ou da repressão da tradução. $O$ gene Aire é um controlador transcricional e pós-transcricional nas células mTEC. Entretanto, pouco se conhece sobre como Aire é controlado. Uma das perguntas 
atuais, a qual foi explorada nesse trabalho, é se Aire poderia ser controlado por microRNAs. Para tentar responder a isso, fizemos uma análise in silico dos microRNAs que predizem hibridação com a região 3'UTR do mRNA de Aire do camundongo Mus musculus. O miR-155 prediz hibridação termodinamicamente estável entre os nucleotídeos 185 e 202 dessa região. Ele é um microRNA exônico que funciona em diferentes tipos celulares e regula diversos processos no sistema imunológico. Nosso trabalho focou então na avaliação funcional do controle pós-transcricional do miR-155 sobre o mRNA de Aire e suas consequências em células mTEC in vitro. A transfecção de células mTEC 3.10 com o miR-155 (mimic) resultou na redução nos níveis do mRNA e da proteína AIRE. Como esperado, a transfecção do miR-155 também resultou na modulação de um conjunto de mRNAs, incluindo aqueles que codificam TRAs, proteínas de adesão mTEC-timócitos, apoptose e splicing alternativo de mRNAs e citocinas de migração celular. As observações moleculares foram validadas experimentalmente quando demonstramos que o miR-155 modula a propriedade quimiotática das células mTEC sobre timócitos. Esses resultados mostraram pela primeira vez que Aire pode ser controlado pelo miR-155 e que esse microRNA também exerce ação ampla em células mTEC.

Palavras-chave: Células tímicas epiteliais medulares (mTECs), Gene autoimmune Regulator (Aire), Controle pós-transcricional, MicroRNA 155, Microarray. 


\section{ABSTRACT}

Tanaka, Pedro Paranhos. Post transcriptional Control of the Autoimmune Regulator (Aire) Gene by the MicroRNA-155. 2019. Dissertação de Mestrado, Faculdade de Medicina de Ribeirão Preto, Universidade de São Paulo, Ribeirão Preto.

The thymus is a primary lymphoid organ where the establishment of central immune tolerance occurs through the elimination of self-reactive $T$ lymphocyte clones. Precursors of $\mathrm{T}$ lymphocytes (termed thymocytes) enter the thymus through the corticalmedullary junction. Thymocytes then undergo two processes, positive selection (which occurs in the thymus cortex and is mediated by cortical thymic epithelial cells or cTECs) and negative selection (which occurs in the medulla and is mediated by medullary thymic epithelial cells or mTECs). During positive selection, only CD4 / CD8 (TCR / $\beta^{+}, \mathrm{CD}^{+}$, $\mathrm{CD}^{+}$) double positive (DP) expressing the functional TCR $/ \beta^{+}$receptor (recognizing $\mathrm{MHC}$ molecules) are selected to migrate to the thymic medulla where negative selection will occur. It will occur on clones of simple positive (SP) thymocytes (TCR $\alpha / \beta^{+}$CD4 ${ }^{+}$or TCR $\left.\alpha / \beta^{+} \mathrm{CD}^{+}\right)$. The mTEC cells express a wide variety of tissue-restricted antigens (TRA) and present them to SP thymocytes. Those clones that recognize some of these autoantigens with high avidity and affinity are deleted by apoptosis and this ends up avoiding peripheral autoimmune aggressiveness. The property of mTECs to express a diverse range of autoantigens was termed promiscuous gene expression (PGE), which encompasses virtually all of the body's tissue antigens. The significance of PGE is essentially immunologic and this ensures the representation of the self-constituents in the thymus gland and consequently setting up of central immunological tolerance. The main PGE controller is the Autoimmune Regulator (Aire) gene, which acts as an unconventional transcription factor and promotes the expression of thousands of TRAS mRNAs in mTECs. In addition, Aire also controls the expression of non-coding RNAs, such as microRNAs. MicroRNAs are small single stranded RNAs ( 22nt) that act on posttranscriptional control through mRNA degradation or translation repression. The Aire gene is a transcriptional and post-transcriptional controller in mTEC cells. However, little is known about how Aire is controlled. One of the current questions, which was explored in this work, is whether Aire could be controlled by microRNAs. To try to respond to this, we performed an in silico analysis of the microRNAs that predicted hybridization with the 
3'UTR region of the mouse (Mus musculus) Aire mRNA. The miR-155 predicts thermodynamically stable hybridization between the nucleotides 185 and 202 of that region. It is an exonic microRNA that works in different cell types and regulates various processes in the immune system. Our work focused on the functional evaluation of the post-transcriptional control of miR-155 on Aire mRNA and its consequences on mTEC cells in vitro. Transfection of mTEC 3.10 cells with miR-155 (mimic) resulted in reduction in mRNA and AIRE protein levels. As expected, miR-155 transfection also resulted in the modulation of a set of mRNAs, including those encoding TRAs, mTEC-thymocyte adhesion proteins, apoptosis, and alternative splicing of mRNAs and cell migration cytokines. Molecular observations were validated experimentally when we demonstrated that miR-155 modulates the chemotactic properties of mTEC cells on thymocytes. These results showed for the first time that Aire can be controlled by miR-155 and that this microRNA also exerts broad action on mTEC cells.

Key-words: Medullary thymic epithelial cells (mTECs), Autoimmune Regulator gene (Aire), Pots-transcription control, MicroRNA-155, Microarray. 


\section{LISTA DE FIGURAS}

Figura 1 - Localização anatômica do timo .21

Figura 2 - Representação esquemática dos processos de seleção positiva e negativa, que ocorrem no timo

Figura 3 - Representação gráfica da porcentagem de TRAs controlados por Aire e Fezf2 .24

Figura 4 - Representação da atuação da proteína AIRE no núcleo das mTECs ......25

Figura 5 - Descrição dos sintomas apresentados por pacientes com APECED......27

Figura 6 - Mutações descritas em AIRE e suas respectivas posições nos domínios da proteína .28

Figura 7 - Representação do mecanismo proposto da ação de AIRE .30

Figura 8 - Classificação dos microRNAs. .33

Figura 9 - Biogênese canônica dos microRNAs em mamíferos 35

Figura 10 Representação da localização genômica do miR-155 em humanos e camundongos. .37

Figura 11 - Papel do miR-155 em diferentes células do sistema imunológico .38 Figura 12 - Predição in silico da interação entre miR-155 e a 3' UTR do mRNA de Aire. .39

Figura 13 - Avaliação temporal dos níveis do miR-155 após transfecção do mimic. .62

Figura 14- Avaliação temporal dos níveis de expressão do mRNA de Aire após transfecção do miR-155 mimic.

Figura 15 - Western Blot da proteína AIRE. .64

Figura 16 - Imunofluorescência da proteína AIRE. .66 
Figura 17 - Perfil de expressão dos mRNAs diferencialmente expressos...............67

Figura 17 - Enriquecimento funcional dos mRNAs super-regulados.......................70

Figura 18 - Enriquecimento funcional dos mRNAs sub-regulados........................71

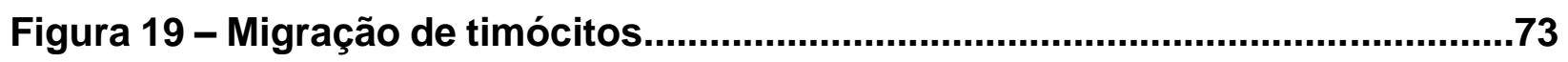




\section{LISTA DE TABELAS}

Tabela 1 - Top mRNAs diferencialmente expressos nas células mTECs 3.10

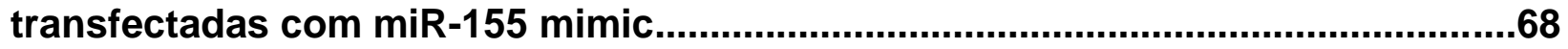

Tabela 2 - mRNAs preditos (MirWalk) como possíveis alvos do miR-155...............69 


\section{LISTA DE ABREVIATURAS}

: aproximadamente

${ }^{\circ} \mathrm{C}$ : graus Celsius

3': extremidade 3'

5': extremidade 5'

APC: Células apresentadoras de antígenos

APECED: Autoimmune Polyendocrinopathy-Candidiasis-Ectodermal Dystrophy

CARD: domínio recrutador de caspase

cTECs: Célula tímica epitelial cortical

DN: Duplo negativo

DP: Duplo positivo

dsRNA: RNA fita dupla

IFN: interferon

IgG: Imunoglobulina G

IL: Interleucina

iNKT: Célula T natural killer invariante

iTregs: Célula T reguladora induzida

$\mathrm{kDa}$ : kilodaltons

MHC: Complexo principal de histocompatibilidade

MIR155HG: MicroRNA 155 host gene

miRISC: Complexo de silenciamento induzido por microRNA

miRNA: MicroRNA

miRNAs: MicroRNA

$\mathrm{mL}$ : mililitro

mM: milimolar

mRNA: RNA mensageiro

ncRNA: RNA não codificante

NLS: Sinal de localização nuclear

nM: nanomolar 
nt: Nucleotídeo

nTregs: Célula T reguladora natural

PGE: Expressão gênica promíscua

PHD: Homeodominio de planta

pre-miRNA: Precursor de microRNA

pri-miRNA: MicroRNA primário

PRR: Região rica em prolina

qRT-PCR: reação de polimerização em cadeia quantitativa e em tempo real

RIN: número de integridade do RNA

RNA pol II: RNA polimerase II

SAND: Domínio denominado SP100, AIRE1, nucP41/P75 and DEAF1

SDS: Dodecil sulfato de sódio

SP: Simple positivo

ssRNA: RNA fita simples

TCR: Receptor de célula T

TEC: Célula tímica epitelial

Th: Célula T helper

TRA: Antígeno restrito a tecidos

Treg: Célula $T$ reguladora

$\mathrm{V}(\mathrm{D}) \mathrm{J}: \mathrm{v}=$ variável, $\mathrm{d}=$ diversidade, $\mathrm{j}=$ junção.

$\mathrm{V}$ : volts

Mg: micrograma

$\mu \mathrm{l}$ : microlitro 


\section{SUMÁRIO}

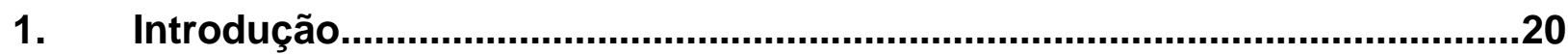

1.1. Desenvolvimento de Linfócitos T e Indução de tolerância central..................20

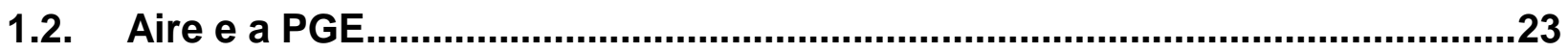

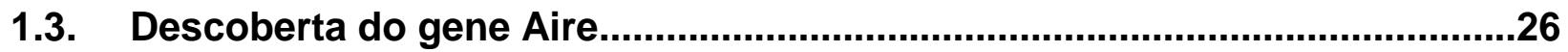

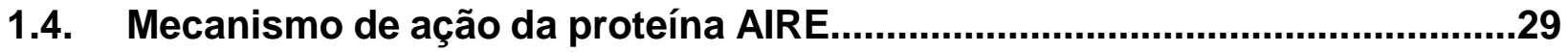

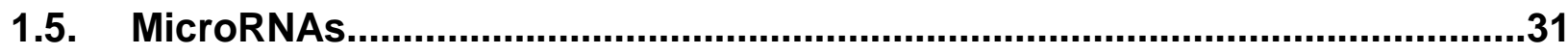

1.6. Classificação e biogênese dos microRNAs.................................................32

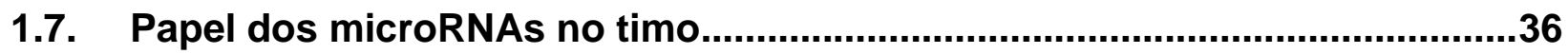

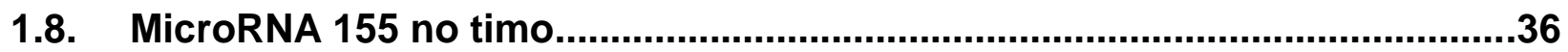

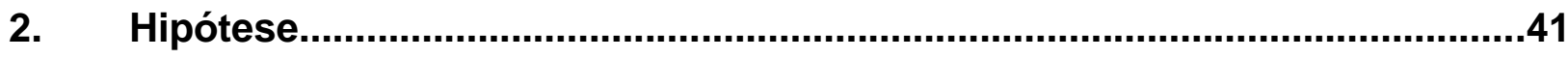

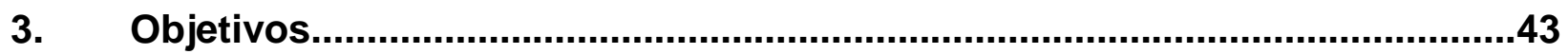

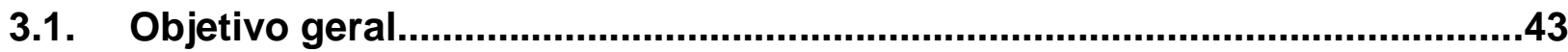

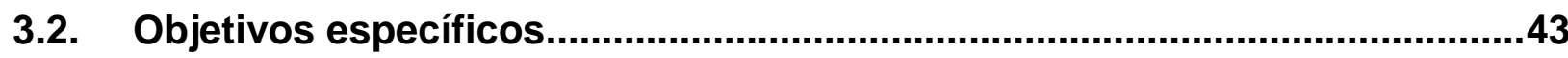

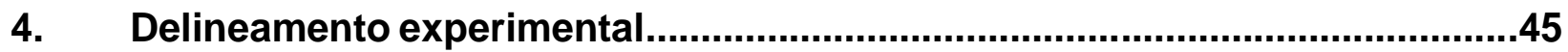

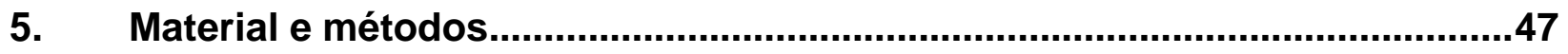

5.1. Predições das interações miR-155-mRNA in silico........................................47

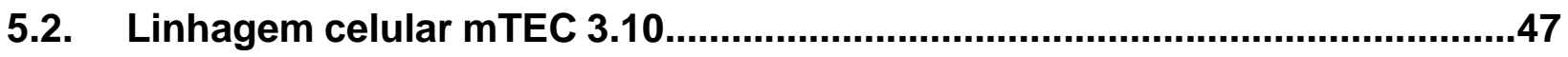

5.3. Transfecção das células mTEC 3.10 com miRNA mimic ................................48

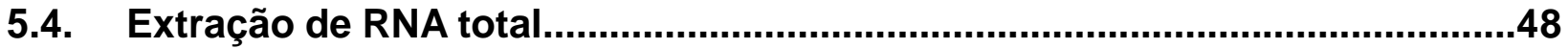

5.5. Quantificação e avaliação do grau de pureza das amostras de RNA total.....49

5.6. Análise da integridade das preparações de RNA total ..................................50

5.7. Transcrição reversa para síntese do cDNA ....................................................51 
5.8. Confirmação da transcrição reversa........................................................51

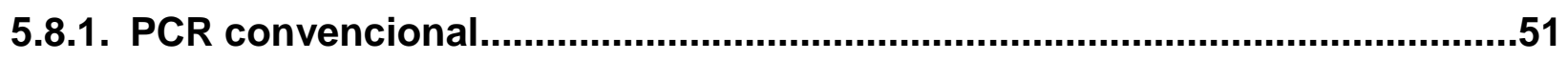

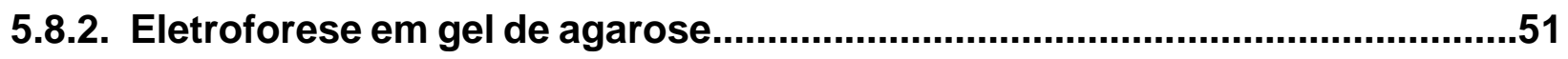

5.9. PCR quantitativa em tempo real (RT-qPCR).............................................52

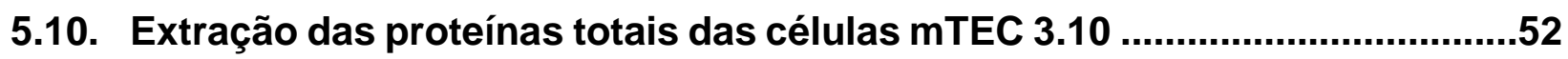

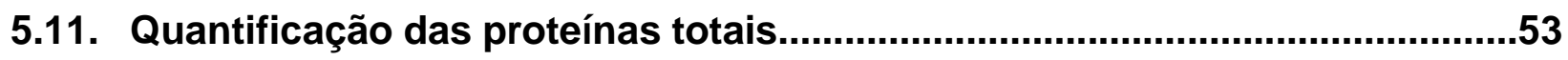

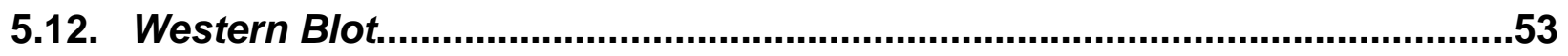

5.13. Ensaio de imunolocalização da proteína AIRE..........................................55

5.14. Avaliação do transcriptoma das células mTEC 3.10 transfectadas com miR-

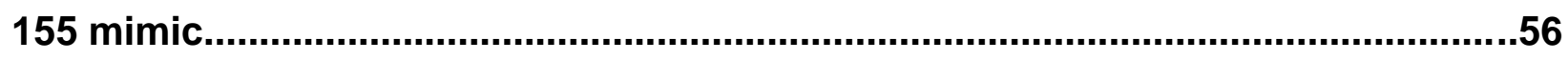

5.15. Análises dos dados de microarrays por bioinformática.................................59

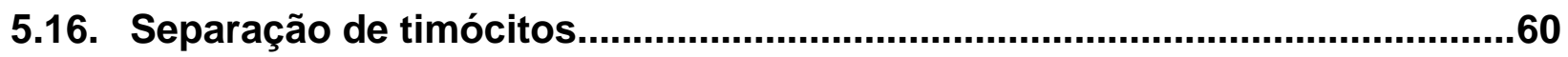

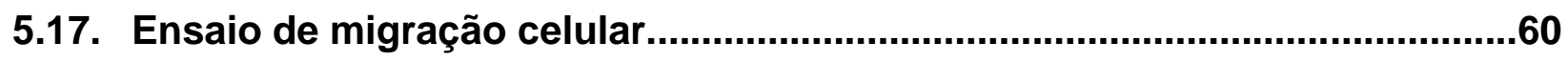

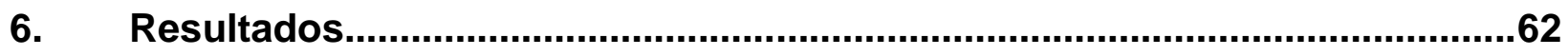

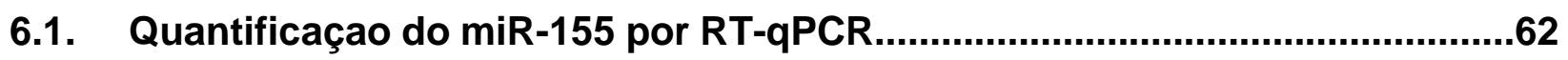

6.2. Quantificação da expressão relativa do mRNA de Aire por RT-qPCR............63

6.3. Análise da expressão da proteína AIRE por Western Blot............................63

6.4. Análise da expressão da proteína AIRE por imunofluorescência..................65

6.5. Análise dos mRNAs diferencialmente expressos em células mTEC 3.10

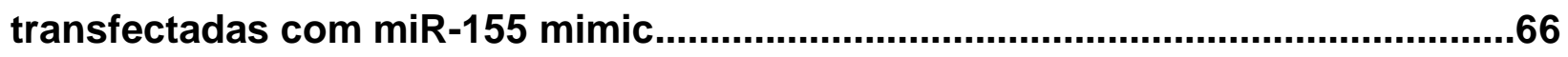

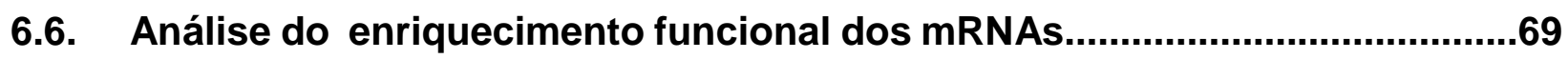

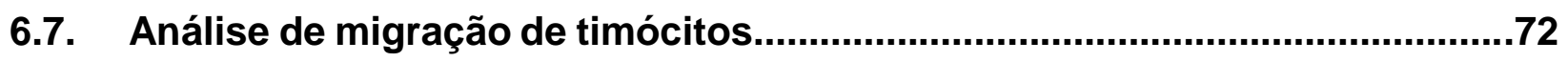

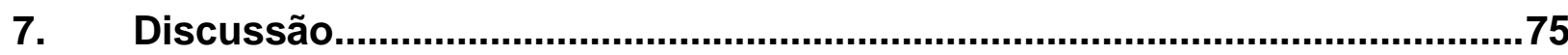




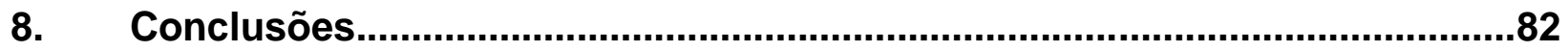

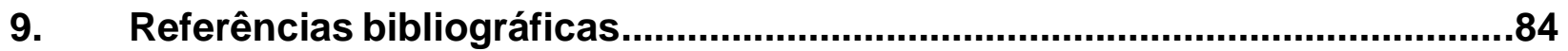

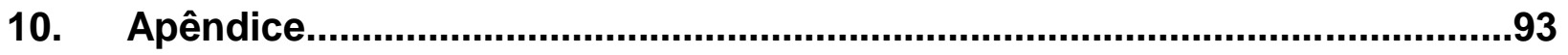

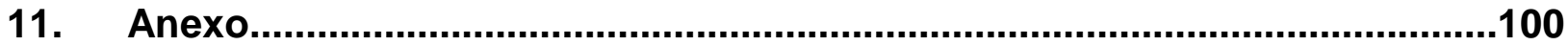




\section{Introdução:}

\subsection{Desenvolvimento dos Linfócito T e Indução da tolerância central}

O sistema imunológico é notável pela sua capacidade de fazer a distinção dos antígenos próprios (auto antígenos), dos não próprios, podendo dessa maneira atuar combatendo esses antígenos estranhos como por exemplo, vírus, bactérias, fungos, parasitos e também células tumorais, e não responder aos autoantígenos. Essa não responsividade é a base do conceito da tolerância imunológica, e falhas no estabelecimento da mesma podem resultar em auto-agressividade mediada pelo sistema imunológico, podendo ter como consequência o desenvolvimento de doenças autoimunes, como por exemplo o diabetes mellitus do tipo 1, artrite reumatoide, lúpus, entre outras (NOSSAL, 1983; KYEWSKI \& DERBINSKI, 2004; IRLA, 2019).

A tolerância imunológica pode ser dividida entre tolerância imunológica periférica e tolerância imunológica central. A primeira é mediada pelas células $T$ reguladoras (Treg), que suprimem a resposta inflamatória na periferia. As Tregs podem ser naturais (nTregs), sendo provenientes de processos das seleções tímicas, ou induzidas (iTregs), que são formadas a partir de células $\mathrm{T} \mathrm{CD}^{+}$na periferia, células essas que falharam no processo de seleção negativa e seriam deletadas. Já a tolerância imunológica central é estabelecida no timo, com a eliminação de células $T$ auto reativas, dando origem a linfócitos maduros e aptos a atuar na periferia (ANDERSON et al., 2007; KYEWSKI \& DERBINSKI, 2004; VASCONCELOS-FONTES et al., 2019).

O timo é um órgão linfoide primário localizado na porção anterossuperior do mediastino e posterior ao osso esterno (Figura 1), e é de fundamental importância para o desenvolvimento e amadurecimento dos linfócitos T (ou células T) (ANDERSON et al., 2007; GEENEN \& SAVINO, 2019). O ambiente intratímico é altamente dinâmico, sendo constituído em sua maioria pelas células tímicas epiteliais (TECs), e contendo também células dendríticas, macrófagos, fibroblastos e células mesenquimais. O timo pode ser histologicamente dividido em duas regiões, o córtex e a medula, onde os precursores de células T passarão pela seleção positiva e a seleção negativa, respectivamente, levando 
assim a indução da tolerância imunológica central (PASSOS et al., 2018; MUNOZ \& ZAPATA, 2019).
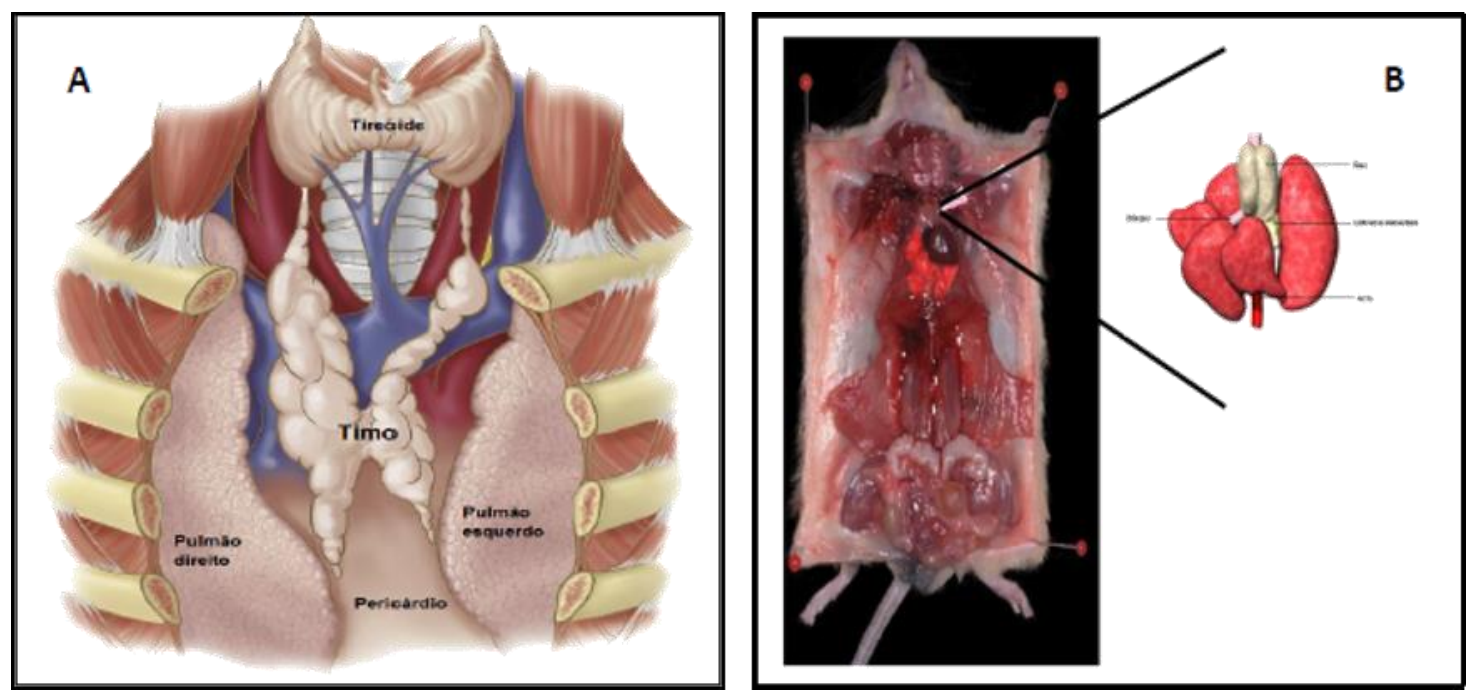

Figura 1. Localização anatômica do timo. A) Posição anatômica do timo em humanos. B) Posição anatômica do timo em camundongos. (Ruehl-Fehlert et al., 2003; Safieddine \& Keshavjee, 2011)

Os precursores de células T são originados na medula óssea e entram no timo pela junção córtico medular, uma vez dentro no timo, passam a ser chamadas de timócitos e são duplo negativos (DN) CD4 e CD8 ${ }^{-}$. Esse timócitos migram através de vasos sanguíneos para o córtex, onde passarão pelo primeiro processo de amadurecimento chamado de seleção positiva que é mediada pelas células tímicas epiteliais corticais (cTECs) (PASSOS et al., 2015, ANDERSON et al., 2007; YOGANATHAN et al., 2019).

$\mathrm{Na}$ seleção positiva esses timócitos $\mathrm{DN}$, que acabaram de passar pela recombinação $V(D) J$ dos genes das cadeias $\alpha$ e $\beta$ dos seus receptores de células $T$ (TCR), serão testados quanto as suas capacidades de reconhecer com baixa afinidade a molécula do complexo principal de histocompatibilidade ( $\mathrm{MHC}$ ) associada a um antígeno próprio nas cTECs, pois posteriormente os antígenos serão apresentados aos linfócitos $\mathrm{T}$ via $\mathrm{MHC}$ classe II. Os timócitos que não reconhecem o $\mathrm{MHC}$ próprio ou em que esse reconhecimento possuiu uma alta afinidade, que poderia desencadear uma resposta autoimune na periferia, são eliminados por apoptose. As células que 
sobrevivem à seleção positiva se tornam timócitos duplo positivos (DP) $\mathrm{CD}^{+}{ }^{+} \mathrm{e} \mathrm{CD}^{+} \mathrm{e}$ migram do córtex para a medula onde passarão pelo segundo processo de seleção (PASSOS et al., 2015, ANDERSON et al., 2007; YOGANATHAN et al., 2019).

A chamada seleção negativa ocorre na medula do timo, onde os timócitos são testados quanto a sua capacidade de reconhecer antígenos restritos a tecidos (TRA), os autoantígenos. Esse processo é mediado especialmente pelas células tímicas epiteliais medulares (mTECs), que possuem uma característica, única e muito interessante, que é chamada de expressão gênica promiscua (PGE), que a capacidade dessa células de expressar uma grande diversidade de genes que normalmente só seriam expressos em seus respectivos órgãos e tecidos, e então apresentar via MHC de classe II esses autoantígenos para os timócitos. Também estão envolvidos nesse processo macrófagos e células dendríticas, que adquirem peptídeos expressos e processados pelas mTECs e atuam como células apresentadoras de antígenos (APC), auxiliando na apresentação de TRAs aos timócitos DP. Os que reconhecem com alta afinidade algum desses autoantígenos são eliminados por apoptose para evitar uma autoimunidade agressiva na periferia ou podem se diferenciar em células T reguladoras. Os timócitos que sobrevivem a esse processo se tornam células T simples positivo (SP) $\mathrm{CD}^{+}{ }^{+}$ou $\mathrm{CD}^{+}$e podem ser direcionadas para periferia, onde atuarão (Figura 2) (PASSOS et al., 2018, ANDERSON et al., 2007; Capitulo 4). 


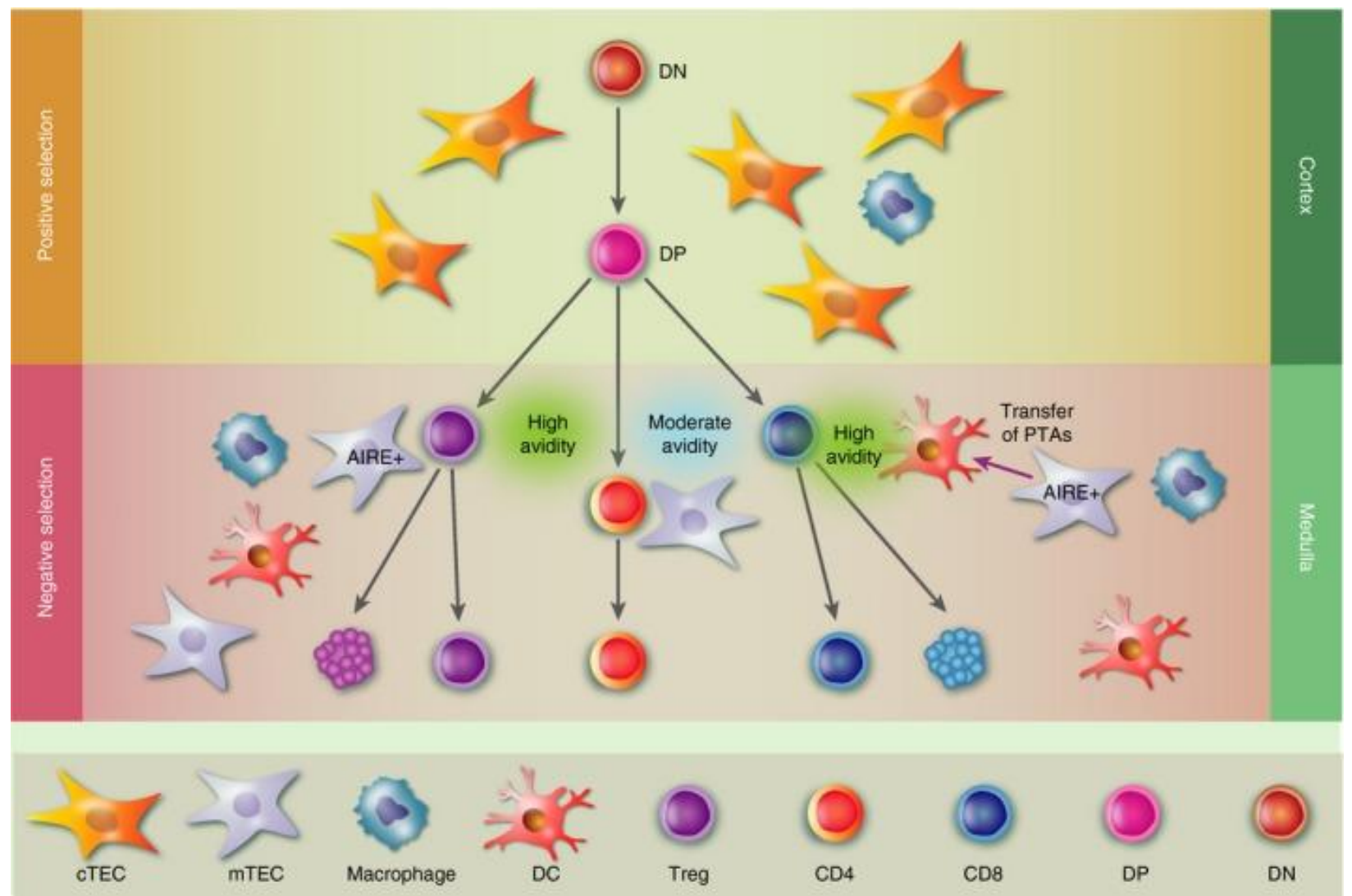

Figura 2. Representação esquemática dos processos de seleção positiva e negativa, que ocorrem no timo. Timócitos DN (CD4 e CD8) passam pelo processo de seleção positiva no córtex do timo, onde são testados, pelas cTECS, quanto a sua capacidade de reconhecer fracamente $\mathrm{O} \mathrm{MHC}$ próprio, os timócitos que falham nesse processo sofrem o processo apoptótico. Após a seleção positiva os timócitos que sobreviveram se tornam DP $\left(\mathrm{CD} 4^{+}\right.$e $\left.\mathrm{CD} 8^{+}\right)$ e migram para a medula do timo, onde passarão pela seleção negativa. Na medula as mTECs irão expressar uma variedade de TRAs e, com o auxílio de outras APCs, irão apresenta-los aos timócitos, os que reconhecem com avidez algum desses autoantígenos, são eliminados por apoptose ou se diferenciam em células Tregs. Os timócitos que sobrevivem a esse processo se tornam SP $\left(C D 4^{+}\right.$e CD8 / CD4 e CD8 $\left.{ }^{+}\right)$e são liberados para a periferia, onde atuarão (Passos et al, 2018).

\subsection{Aire e a PGE}

A PGE é uma propriedade das mTECs altamente conservada entre camundongos e humanos, e é caracterizada pela expressão no timo de genes ectópicos, fazendo das mTECs o tipo celular, conhecido até o momento, com a maior quantidade de genes expressos (SANSOM et al., 2014; PASSOS et al., 2019). A expressão gênica promíscua é de extrema importância para garantir a eliminação de células $T$ auto reativas, a 
expressão de diversos TRAs na seleção negativa garante que a tolerância central se estenda, virtualmente, para todos os tecidos do corpo. Porém é importante ressaltar que esse alcance se dá pela população total de mTECs no timo, uma vez que um único TRA é expresso por uma pequena parcela de células (1-3\%) (KLEIN et al, 2014, ST-PIERRE et al., 2015).

Um dos principais controladores da PGE nas mTECs é o gene Aire (Autoimmune Regulator), que codifica a proteína AIRE, que atua como um fator de transcrição não canônico promovendo a expressão de diversos TRAs (ANDERSON \& SU, 2016, MATHIS \& BENOIST, 2007, KYEWSKI \& DERBINSKI, 2004; GIRAUD \& PETERSON, 2019). De acordo com Takaba et al (2015) 28.9\% dos TRAs expressos em mTECs estão sobre o controle de Aire e são chamados de aire dependentes, além disso uma outra parcela de $12.3 \%$ estão sobre o controle de Aire e Fezf2, os outros 58.8\% não estão sobre o controle de Aire e são chamados de Aire independentes (Figura 3).

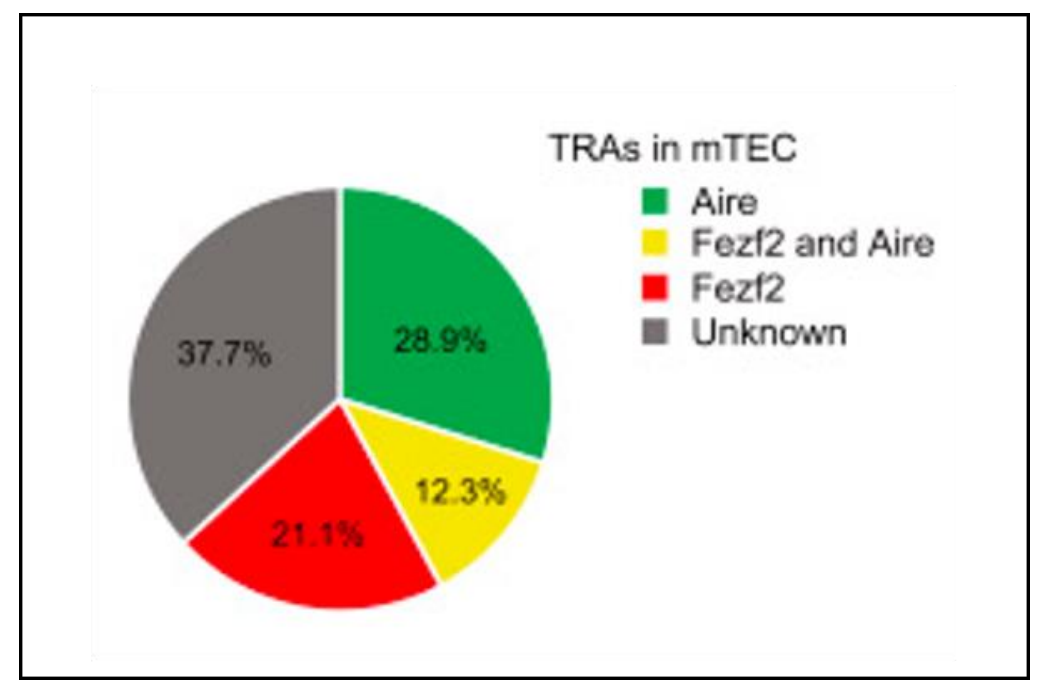

Figura 3. Representação gráfica da porcentagem de TRAs controlados por Aire e Fezf2 (Takaba et al, 2015)

O gene Aire é expresso em apenas alguns tecidos, mas em sua maioria no timo e mais especificamente em mTECs (ANDERSON et al., 2002). Além disso apenas uma subpopulação de mTECs maduras com fenótipo CD80 ${ }^{\text {hi }} \mathrm{MHC}$ - $I^{\text {hi }}$, expressam o gene, chamada de mTEC $^{\text {hi }}$ Aire $^{+}$(SANSOM et al., 2014, ST-PIERRE et al., 2015). A proteína AIRE atua como um fator de transcrição não clássico no núcleo das mTECs, promovendo 
a expressão de diversos TRAs Aire dependentes (ANDERSON et al., 2002, PASSOS et al., 2018; PASSOS et al., 2019) (Figura 4). Também foi mostrado a importância de Aire para o amadurecimento e controle da proliferação dessas mTECs, além de sua importância no processo de adesão entre mTEC timócitos durante a seleção negativa (ANDERSON et al., 2002, PASSOS et al., 2018, UCAR et al., 2013; PASSOS et al., 2019; MENDES-DA-CRUZ et al., 2019).

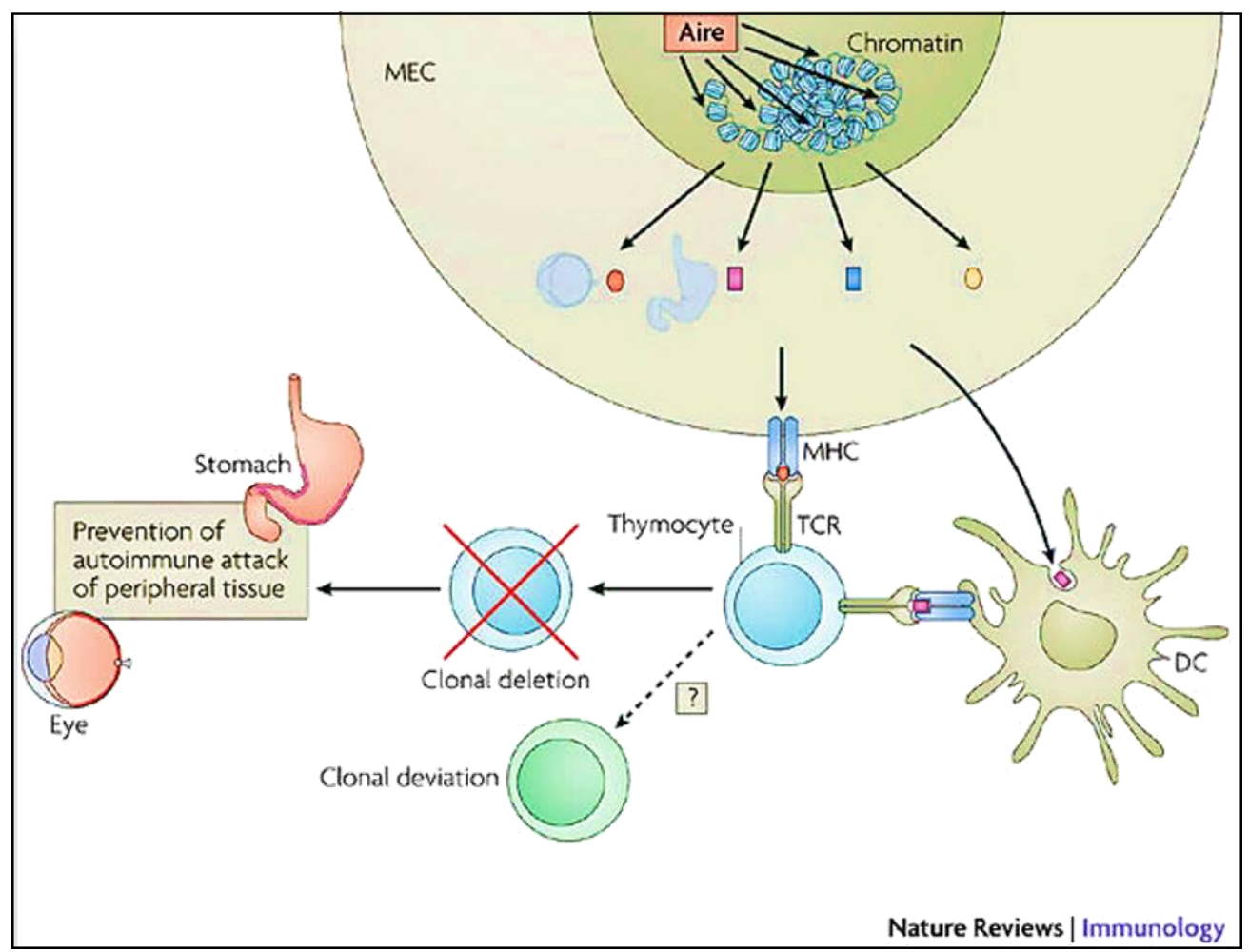

Figura 4. Representação da atuação da proteína AIRE no núcleo das mTECs. AIRE atua no núcleo das mTECs promovendo a expressão de TRAs dos diferentes tecidos e/ou órgãos. Esses TRAs são então apresentados via MHC ao timócitos durante a seleção negativa. Os clones que reconhecem com alta afinidade esses TRAs são eliminados por apoptose. (Mathis \& Benoist 2007).

As mTECs imaturas CD80 low $\mathrm{MHC}$-IIlow, que não expressam Aire, expressam um conjunto menor de TRAs enquanto que a população de mTEC $^{\text {hi }}$ Aire $^{+}$chega a expressar até $62 \%$ dos genes codificadores de proteínas em camundongos (PASSOS et al., 2019; PASSOS et al., 2018, ST-PIERRE et al., 2015). Porém é importante ressaltar que não são apenas genes codificadores de antígenos restritos a tecidos que estão dentre esses $62 \%$. São considerados codificadores de um TRA aqueles genes que estão enriquecidos 
(em relação à média de expressão dentre todos os tecidos) em no máximo 5 tecidos (STPIERRE et al., 2015, SANSOM et al., 2014). De fato, AIRE promove a expressão de aproximadamente $14 \%$ dos genes expressos em camundongos, desses aproximadamente $25 \%$ se encaixam na definição de TRAs, portanto a maior parte dos genes controlados por Aire não são TRAs, mas também estão envolvidos em outros processos importantes nas mTECs (ST-PIERRE et al., 2015).

Além dos TRAs, que são de extrema importância para testar os timócitos quanto a sua auto reatividade, estudos têm mostrado que diversos genes Aire dependentes possuem diferentes funções nas mTECs, participando de processos como a diferenciação e amadurecimento dessas células, interações das mTECs com timócitos e células dendríticas, induzem a migração de timócitos para o timo e pelo o timo, apoptose das mTECs e até mesmo papel no processamento de mRNAs (splicing alternativo), contribuindo para expressão de isoformas de TRAs nas mTECs. (ST-PIERRE et al., 2015, SANSOM et al., 2014, PASSOS et al., 2018, ANDERSON \& SU, 2016, ABRAMSON et al., 2010, PEZZl et al., 2016 ; PASSOS et al., 2019).

\subsection{Descoberta do gene Aire}

A descoberta de Aire como um fator de transcrição não canônico da PGE se deu através do estudo de uma doença autoimune sistêmica chamada de poliendocrinopatia autoimune tipo 1 (Autoimmune Polyendocrinopathy-Candidiasis-Ectodermal Dystrophy APECED) (BRUSERUD et al., 2016, PETERSON et al., 2004; GIRAUD \& PETERSON, 2019). A APECED é uma doença monogênica autossômica recessiva com sintomas devastadores nos pacientes. Apesar de ser uma doença rara possui uma maior incidência em determinadas regiões, como por exemplo na Finlândia (1/25.000), Sardenha (1/14.400) e a população de judeus no Irã (1/9.000) (HUSEBYE et al., 2009).

A APECED é caracterizada por três sintomas principais: candidíase mucocutânea crônica, hipoparatireoidismo e a insuficiência adrenal (PETERSON et al., 2004; GIRAUD \& PETERSON, 2019). Dois entre esses 3 sintomas são necessários para classificar um indivíduo como portador da síndrome. Além desses 3 clássicos sintomas, pacientes com APECED podem apresentar uma variedade de outras manifestações autoimunes, porém 
que ocorrem com menor frequência e são muito variáveis entre pacientes, como por exemplo: hepatite, tireoidite, diabetes mellitus tipo I, alopecia, hipotireoidismo, entre outros (Figura 5) (NAGAMINE et al., 1997, BRUSERUD et al., 2016, HUSEBYE et al., 2009).

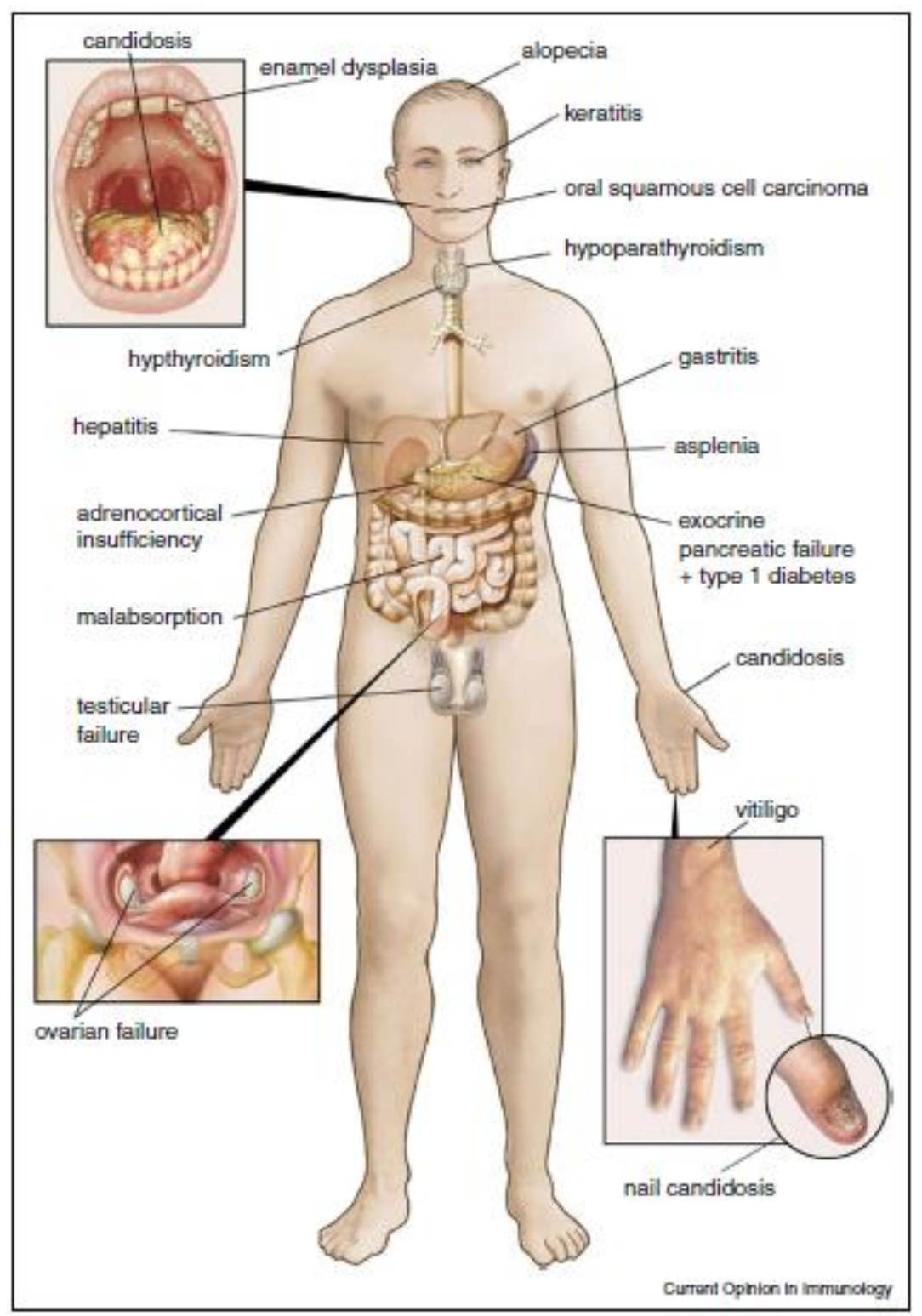

Figura 5. Descrição dos sintomas apresentados por pacientes com APECED. Possui quadro clínico altamente variável, tendo como os 3 principais sintomas a candidíase mucocutânea crônica, insuficiência adrenal e hipoparatireoidismo (Bruserud et al, 2016). 
Apesar de ter sido descrita pela primeira vez na década de 60 (BLIZZARD \& KYLE, 1963), somente em 1997 foi identificado, por dois grupos diferentes, o gene envolvido na APECED (AALTONEN et al., 1997, NAGAMINE et al., 1997). Denominado de gene Aire, ele foi localizado no cromossomo 21q22.3 em humanos, com 14 exons e codificando uma proteína de 545 aminoácidos de aproximadamente $57 \mathrm{kDa}$, já em camundongos ele está localizado no cromossomo $10 \mathrm{C} 1$. Mais de 100 mutações já foram identificadas no gene Aire (Figura 6), variando desde uma alteração em um único nucleotídeo até deleções de grandes regiões, resultando em uma proteína truncada e/ou não funcional (BRUSERUD et al., 2016).

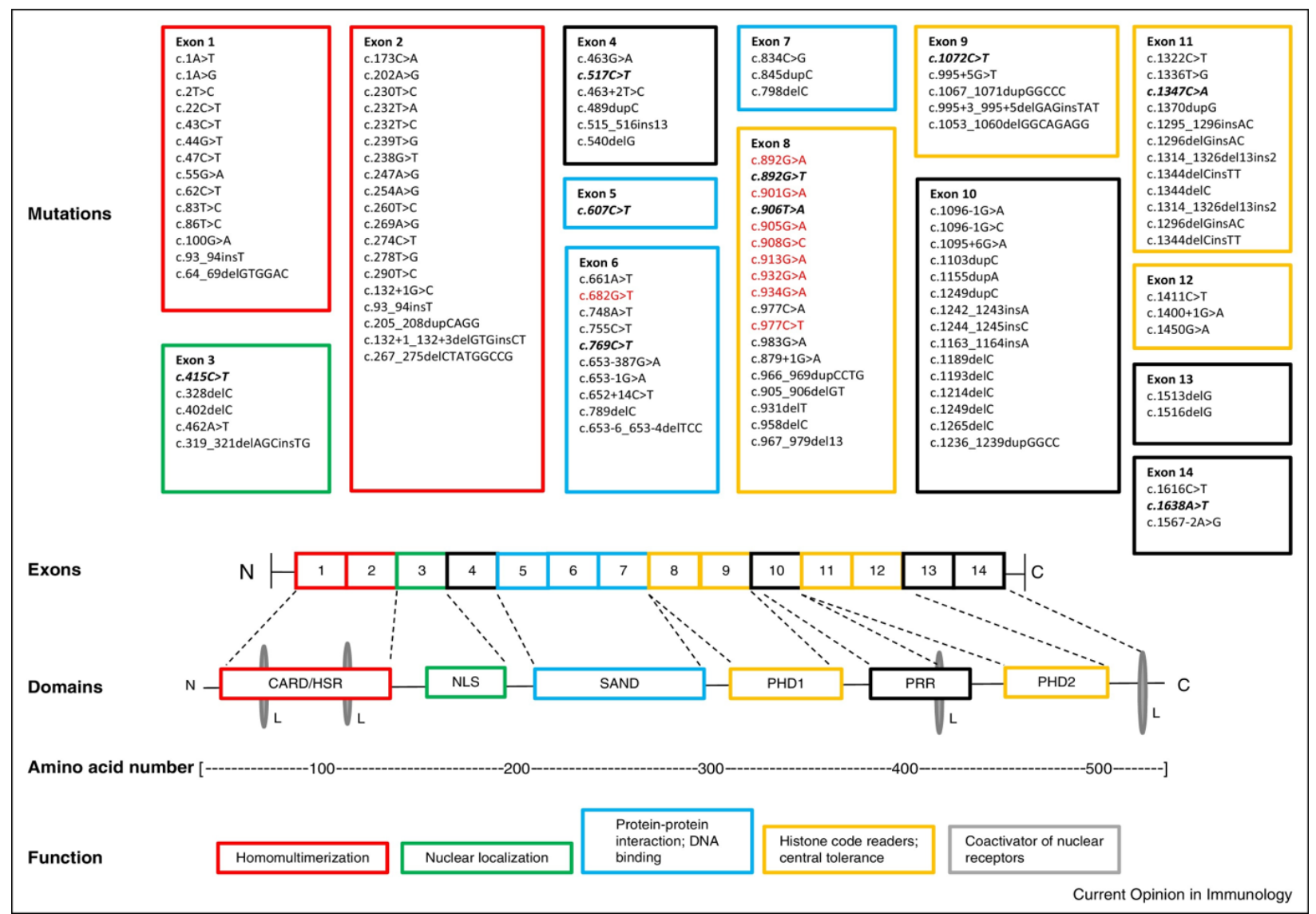

Figura 6. Mutações descritas em AIRE e suas respectivas posições nos domínios da proteína. Mais de 100 mutações já foram descritas nos diferentes domínios funcionas da proteína AIRE (Bruserud et al, 2016). 


\subsection{Mecanismo de ação da proteína AIRE}

A proteína AIRE é composta por cinco subdomínios principais (Figura 6): domínio CARD (caspase recruiter domain), que atua na homomultimerização da proteína, uma vez que AIRE atua como um tetrâmero no núcleo das mTECs; domínio NLS (nuclear location signal), que tem a função de sinalizar a proteína para o núcleo; domínio SAND, que está envolvido nas interações proteína-proteína que possibilita a atuação de AIRE em conjunto com suas proteínas parceiras; e 2 domínios PHD, PHD-1 e PHD-1, separados por uma região rica em prolina (PRR), e que atuam como leitores de código de histonas, auxiliando na descondensação da cromatina (PASSOS et al., 2018, ANDERSON \& SU, 2016, BRUSERUD et al., 2016).

AIRE atua como um fator de transcrição não convencional no núcleo das mTECS, isso porque ela não reconhece nenhum motif no DNA para promover a transcrição, na realidade a proteína AIRE interage com a molécula da RNA polimerase Il que já iniciou o processo de transcrição, porém está "ancorada" na cromatina nos sítios específicos Tboxes (TTATTA) e G-boxes (ATTGGTTA) das regiões promotoras dos genes aire dependentes e é então liberada por AIRE, promovendo a elongação da transcrição de milhares de genes (GIRAUD et al., 2012) .

Como já citado a proteína AIRE não atua sozinha, mas está associada à outras proteínas denominadas de parceiras de Aire, que atuam em conjunto para promover a expressão dos genes Aire dependentes nas mTECs. Entre elas nós temos a Deacetylase sirtuin 1 (SIRT-1), que promove a deacetilação de resíduos de lisina em AIRE, resultando em sua ativação. Uma vez ativada, AIRE reconhece e se liga a marcas epigenéticas de repressão de transcrição como H3K4me0. A topoisomerase II (TOP2a) se associa a AIRE e promove a quebra da fica dupla do DNA, DNA PKs e outras parceiras são ativadas com a quebra da dupla fita e promovem o relaxamento da cromatina. $O$ complexo de proteínas Bromodomain-containing 4 (Brd4) e Positive transcription elongation factor b (pTEFb) se associam a AIRE e são responsáveis por libera a RNA pol Il que está parada na cromatina. Já a CREB-binding protein (CBP) é responsável por acetilar os resíduos de lisina de AIRE levando a sua inativação (Figura 7) (PASSOS et al., 2018, ANDERSON \& SU, 2016). 


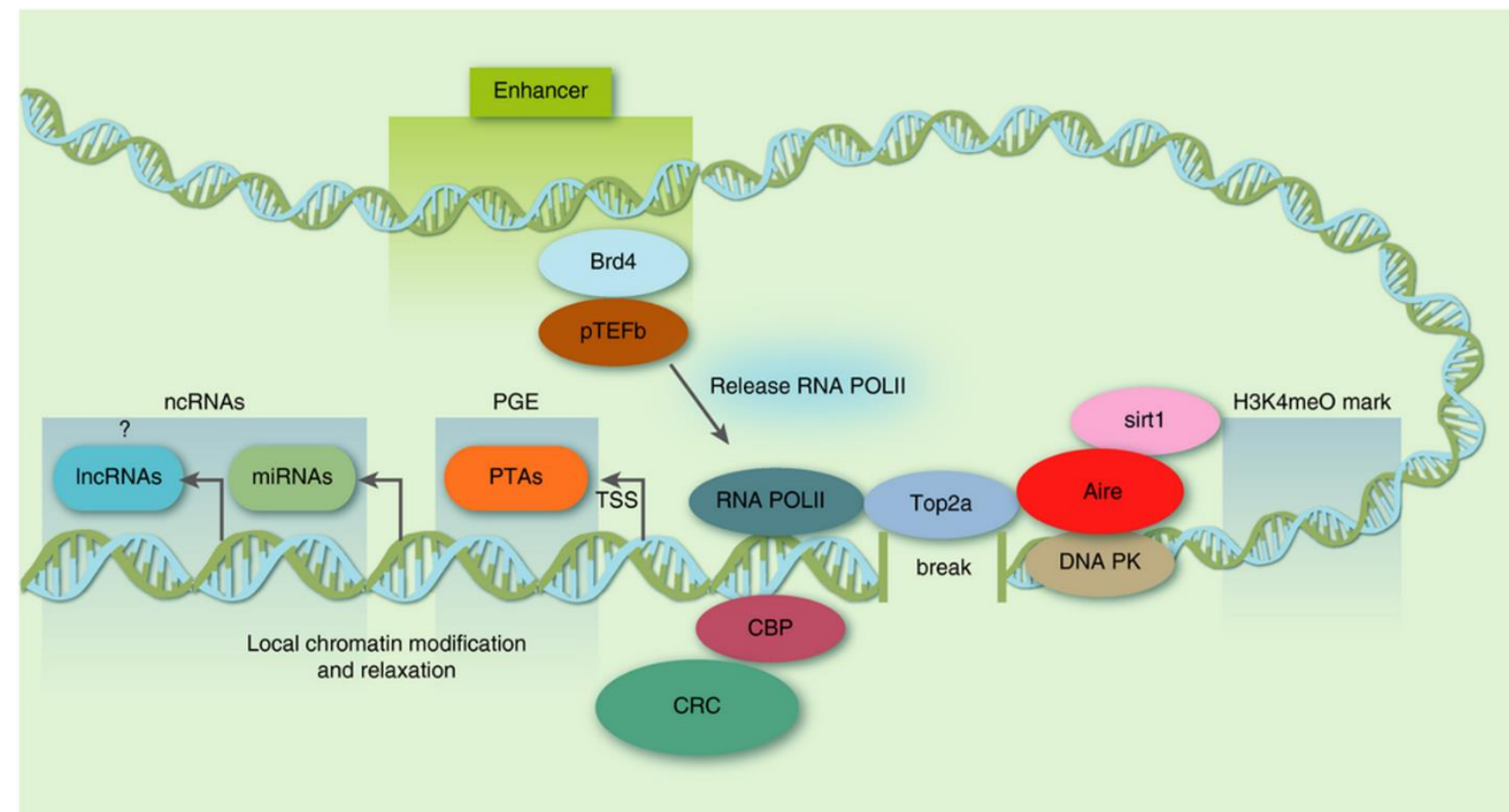

Figura 7. Representação do mecanismo proposto da ação de AIRE. Sirt-1 deacetila resíduos de lisina de AIRE promovendo sua ativação, AIRE então reconhece marcas epigenéticas de repressão da tradução (H3K4me0), se liga à essas marcas e recruta outras proteínas. TOP2a promove a quebra da fita dupla, DNA PKs em conjunto com suas parceiras promove 0 relaxamento da fita e o complexo Brd4 e pTEFb liberam a RNA pol II que está "ancorada" na cromatina, levando a transcrição de diversos genes. Finalmente a CBP acetila os resíduos de lisina de AIRE, inativando-a (Passos et al, 2018).

Devido a sua forma peculiar de ação, reconhecendo marcas epigenéticas de repressão da tradução e assim, promovendo a transcrição de maneira não seletiva de genes transcritos pela RNA pol II, AIRE deve ser considerado um fator de transcrição não convencional, que possibilita não apenas a transcrição de genes codificadores de proteína, como os TRAs aire dependentes, mas também de ncRNA, como microRNAs (miRNAs) e RNA longos não codificadores, uma vez que esses também são transcritos pela RNA pol II (MACEDO et al., 2013).

Aire é de extrema importância para a indução da tolerância central, sendo essencial nas mTECs e atuando como um grande controlador da PGE, porém muito ainda não se está elucidado sobre Aire, e uma das perguntas a serem respondidas é o que pode estar regulando-o. Nesse contexto surgem os microRNAs como possíveis controladores pós-transcricionais do gene Aire. 
Matsuo e colaboradores (2013) demonstraram um possível controle do Aire pelo miR-220b, porém a expressão do miR-220b nunca foi demonstrada em nenhum outro animal além de zebrafish, e após os resultados obtidos por Chiang e colaboradores (2010), o miR-220b foi desconsiderado como um microRNA, portanto até o momento da realização deste trabalho, nenhum microRNA individual foi, de fato, identificado como possível regulador pós transcricional de Aire.

\subsection{MicroRNAs}

Os miRNAs compreendem um grande grupo de pequenos RNAs endógenos fita simples de aproximadamente 22 nucleotídeos de comprimento, que são essenciais na regulação pós transcricional. MicroRNAs servem como guias da proteína Argonauta (AGO) reconhecendo, por complementariedade total ou parcial, sítios na região 3'UTR de mRNAs alvos. A proteína AGO carregada com o miRNA forma o complexo de silenciamento induzido por microRNA (miRISC - miRNA-induced silencing complex) e participa do controle pós transcricional, de animais e plantas, através da repressão da tradução ou degradação do mRNA (GEBERT \& MACRAE, 2018, KROL et al., 2010).

O primeiro miRNA foi descoberto em 1993 por Lee e colaboradores. Ao estudarem o verme Caenorhabditis elegans, identificaram o miRNA lin-4, localizado na região intrônica de um gene que não codificava uma proteína, mas sim 2 pequenos RNAs de 21 e 61 nucleotídeos de comprimento. Observaram também que o RNA mais longo (61 nucleotídeos) formava uma estrutura de grampo que era precursora do RNA menor (21 nucleotídeos). Posteriormente foi observado que lin-4 possuía complementariedade em vários sítios da 3'UTR do gene LIN-14 (WIGHTMAN et al., 1993, LEE et al., 1993), e era essencial no processo de desenvolvimento da fase larval do nematódeo através da inibição do gene LIN-14. Let-7 foi o segundo miRNA descoberto, em 2000 (REINHAR et al., 2000, SLACK et al., 2000) também em C. elegans. Originalmente acreditava-se que esses pequenos RNAs eram exclusivos do nematódeo, mas atualmente 2654 miRNAs maduros estão descritos no banco de dados miRBase (www.mirbase.org) para Homo sapiens e 1978 para Mus musculus, e sabe-se da importância da participação de miRNAs em diversos processos biológicos. 
Devido ao seu pequeno tamanho um único miRNA pode ter múltiplos alvo. Em mamíferos é predito que cerca de metade dos genes codificadores de proteína são controlados pós transcricionalmente por microRNAs e estudos mostram que a grande maioria dos processos celulares conhecidos estão sob o controle de miRNAs (KROL et al., 2010, WAHID et al., 2010 GEBERT et al., 2018), mostrando a importância desses pequenos RNAs fita simples.

\subsection{Classificação e biogênese dos microRNAs}

Os microRNAs podem ser classificados quanto a sua posição no genoma (Figura 8): o miRNA intergênico é aquele que se encontra em regiões distintas de unidades de transcrição conhecidas, possuindo seu próprio promotor, esses miRNAs podem estar agrupados de maneira que mais de um miRNA possui um promotor em comum; os miRNAs intrônicos são aqueles encontrados nos introns de genes conhecidos possuindo o mesmo promotor do gene em que se encontra, os miRNAs intrônicos também podem estar agrupados de maneira que todos compartilham o promotor com o gene, há também um caso especial entre os miRNAs intrônicos em que o miRNA possui o comprimento exato de um dos introns do gene, nesse caso ele passa a ser denominado de mirtron e possui uma via de processamento não canônica; e o miRNA exônico é aquele que se encontra no exon de um gene, esse tipo de miRNA é mais raro e muitas vezes pode abranger uma parte do intron e do exon desse gene, compartilhando o promotor com 0 mesmo (OLENA \& PATTON, 2014). 


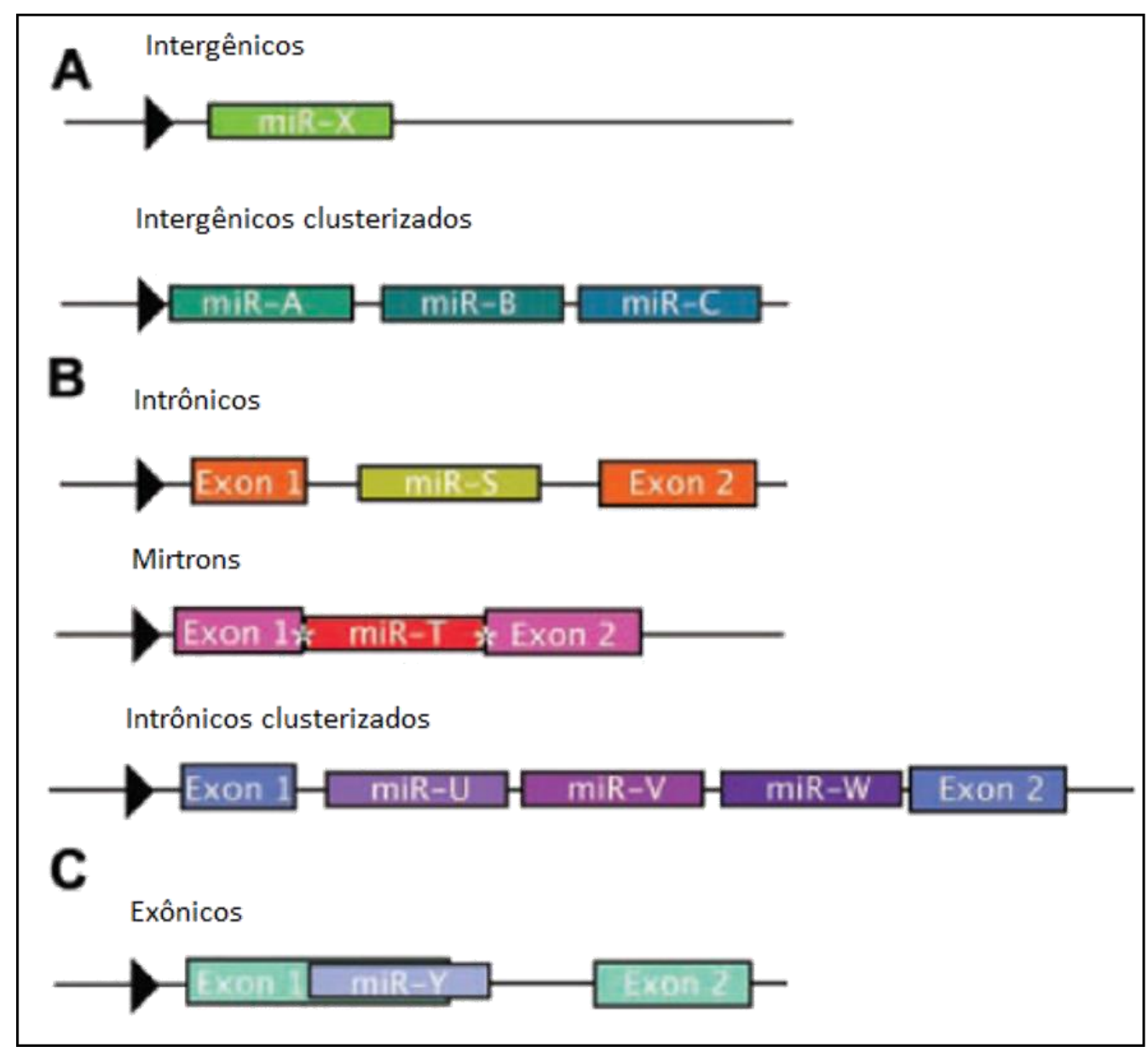

Figura 8. Classificação dos microRNAs. A) Os miRNA intergênicos se encontram em regiões distintas de unidades de transcrição de outros genes, possuindo próprio promotor, e podendo estar clusterizados de maneira que compartilham o mesmo promotor. B) miRNAs intrônicos são aqueles localizados nos introns de genes conhecidos, compartilhando o mesmo promotor com o gene, também podendo estar clusterizados; os mirtrons são uma classe específica de miRNAs intrônicos que possuem tamanho exato do intron de um gene e são processados através de uma via não canônica. C) Os miRNAs exônicos estão localizados nos exons de genes, compartilhando o promotor com os mesmos e podendo abranger parte do exon e parte do intron (Adaptado de Olena \& Patton, 2010).

A biogênese dos microRNAs em mamíferos se inicia no núcleo com a transcrição de genes de miRNAs pela RNA pol II. Na via canônica, o transcrito gerado chamado de miRNA primário (pri-miRNA), possui uma longa sequência de centenas de nucleotídeos com a porção 5' ligada a 7-metil guanosina e a cauda poli-A na região 3', e possui uma sequência complementar a si mesmo, dando origem a uma estrutura em forma de grampo (hairpin). O pri-miRNA é então processado ainda dentro do núcleo pela Drosha em associação com a DGCR8, que clivam a aproximadamente 11 nucleotídeos da 
junção dsRNA-ssRNA, dando origem a uma sequência de 70-120 nucleotídeos de comprimento, chamada de precursor de microRNA (pre-miRNA). O precursor é então exportado par o citoplasma pela exportin-5, onde passará por um segundo processamento (KROL et al., 2010, WAHID et al., 2010 GEBERT et al., 2018).

$\mathrm{Na}$ via não canônica os microRNAs, que nesse caso são classificados como mirtrons, são processados por meio de splicing, dando origem ao pre-miRNA (SHUKLA et al., 2011, OLENA \& PATTON, 2014).

Já no citoplasma o pre-miRNA será processado pela Dicer, perdendo a estrutura em forma de grampo e dando origem ao miRNA maduro dupla fita de aproximadamente 22 nucleotídeos de comprimento. Uma das fitas do duplex é denominada de fita de passagem e será degradada, a outra, denominada de fita guia, se associa com a proteína argonauta (AGO), formando o RISC. Em determinados microRNAs ambas as fitas podem se associar a proteína AGO (Figura 9) (KROL et al., 2010, WAHID et al., 2010 GEBERT et al., 2018). 


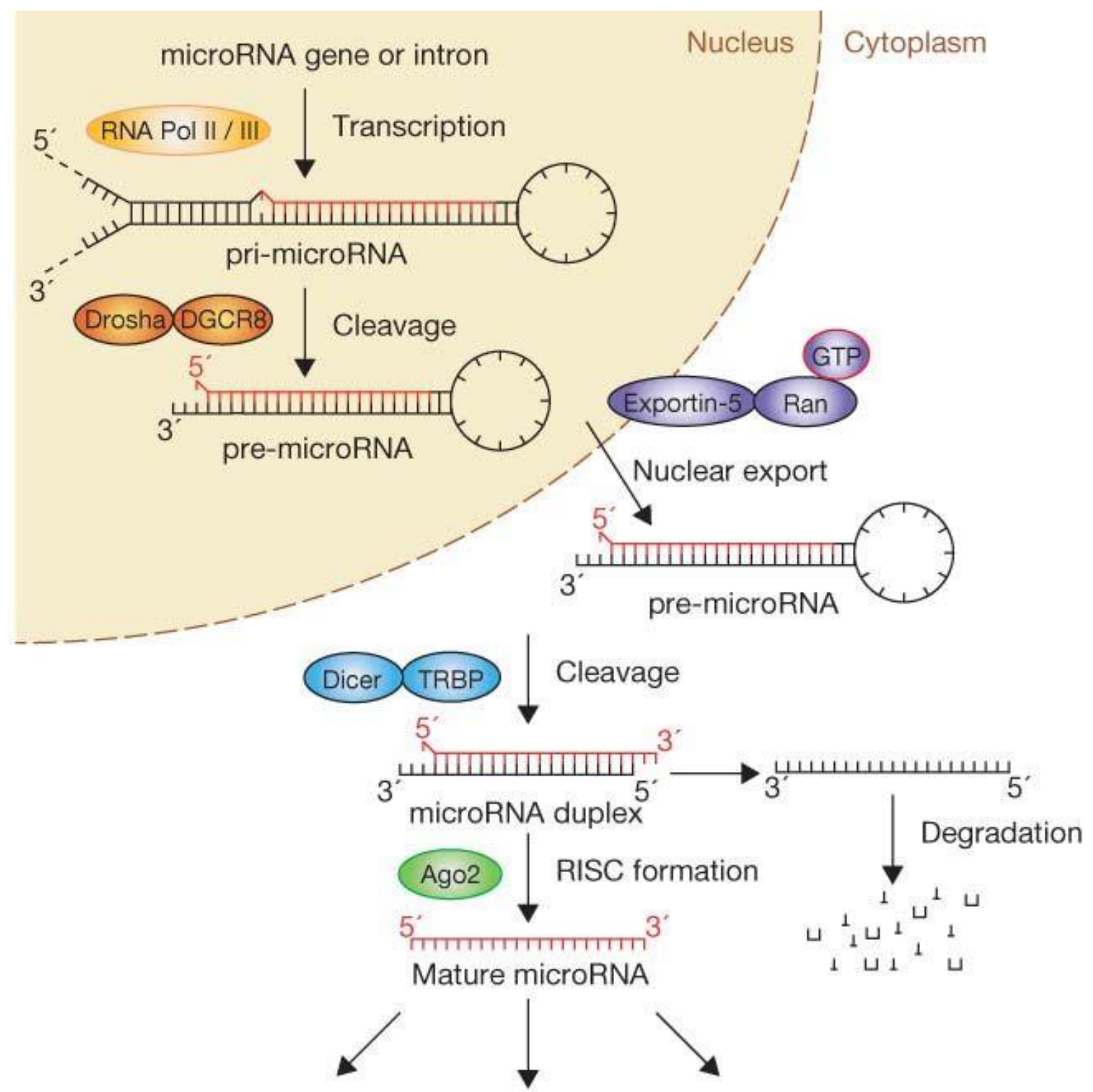

mRNA target cleavage Translational repression mRNA deadenylation

Figura 9. Biogênese canônica dos microRNAs em mamíferos. O miRNA é transcrito pela RNA pol II, dando origem a uma longa sequência de RNA chamada de pri-miRNA que assume a forma de grampo, ainda dentro do núcleo esse pri-miRNA é processado pela Drosha com o auxílio da DGCR8, gerando uma sequência menor chama de pre-miRNA, porém ainda em forma de grampo. O pre-miRNA é exportado para o citoplasma pela exportin-5, onde sofrerá um segundo processamento, agora pela Dicer, perdendo assim a estrutura de grampo e dando origem a um duplex de RNA de aproximadamente $22 \mathrm{nt}$. Uma das fitas do duplex (fita guia) se associará a proteína AGO formando o RISC enquanto a outra será degradada (fita de passagem) (Winter et al, 2009) 


\subsection{Papel dos microRNAs no timo}

Devido a importância dos miRNAs em diversas vias e processos, não é difícil de se questionar quanto seu papel no timo, de fato diversos trabalhos recentes mostraram a importância dos microRNAs no timo e para o sistema imunológico como um todo, uma vez que a expressão anormal de miRNAs está associada a diversas doenças autoimunes. Vários miRNAs estão associados ao desenvolvimento e homeostase do ambiente intratímico (PASSOS et al., 2015, KHAN et al., 2014, XU et al., 2018).

Olga e colaboradores (2013) mostraram que a falta de Dicer, que é essencial para a biogênese dos miRNAs, compromete a sobrevivência das células $T$ de cadeia $\alpha \beta$ e causa a produção anormal de citocinas, reduz bruscamente a número de células Treg e causa um bloqueio parcial no desenvolvimento das células B. A deleção de Dicer em TECs causa uma redução progressiva na expressão de Aire e da PGE, e resulta em uma involução prematura do timo, com uma desorganização progressiva do epitélio tímico levando à formação de "vazios" na sua glândula.

Os microRNAs Dicer dependentes também possuem um papel importante no desenvolvimento e função de células T natural killer (iNKT), a participam na maturação, diferenciação, desenvolvimento e sobrevivência dos linfócitos (XU et al., 2018).

Khan e colaboradores (2014) geraram camundongos com deleção da DGCR8 específica para TEC, demonstrando a importância dos miRNAs canônicos para a arquitetura tímica, mais especificamente na celularidade das mTECs e sua maturação, além de sua importância para a manutenção de mTECs Aire ${ }^{+}$.

Nosso grupo de pesquisa mostrou pela primeira vez que Aire controla a expressão de microRNAs, uma vez que esses também são transcritos pela RNA pol II (MACEDO et al., 2013), que em conjunto com os outros resultados citados mostra uma interdependência entre Aire e miRNAs.

\subsection{MicroRNA 155 no timo}

O miR-155 é um microRNA exônico, codificado pelo MIR 155 host gene (MIR155HG), em humanos esse gene está localizado no cromossomo 21q21.2 possui 
três exons e é transcrito em um pri-miRNA de 1474 nt, a sequência do microRNA maduro está situado no exon 3. Já em camundongos o gene está localizado no cromossomo 16 C3.3, possui 2 exons e da origem a um pri-miRNA de 1264 nt, em que o miRNA maduro está localizado no exon 2 (Figura 10).

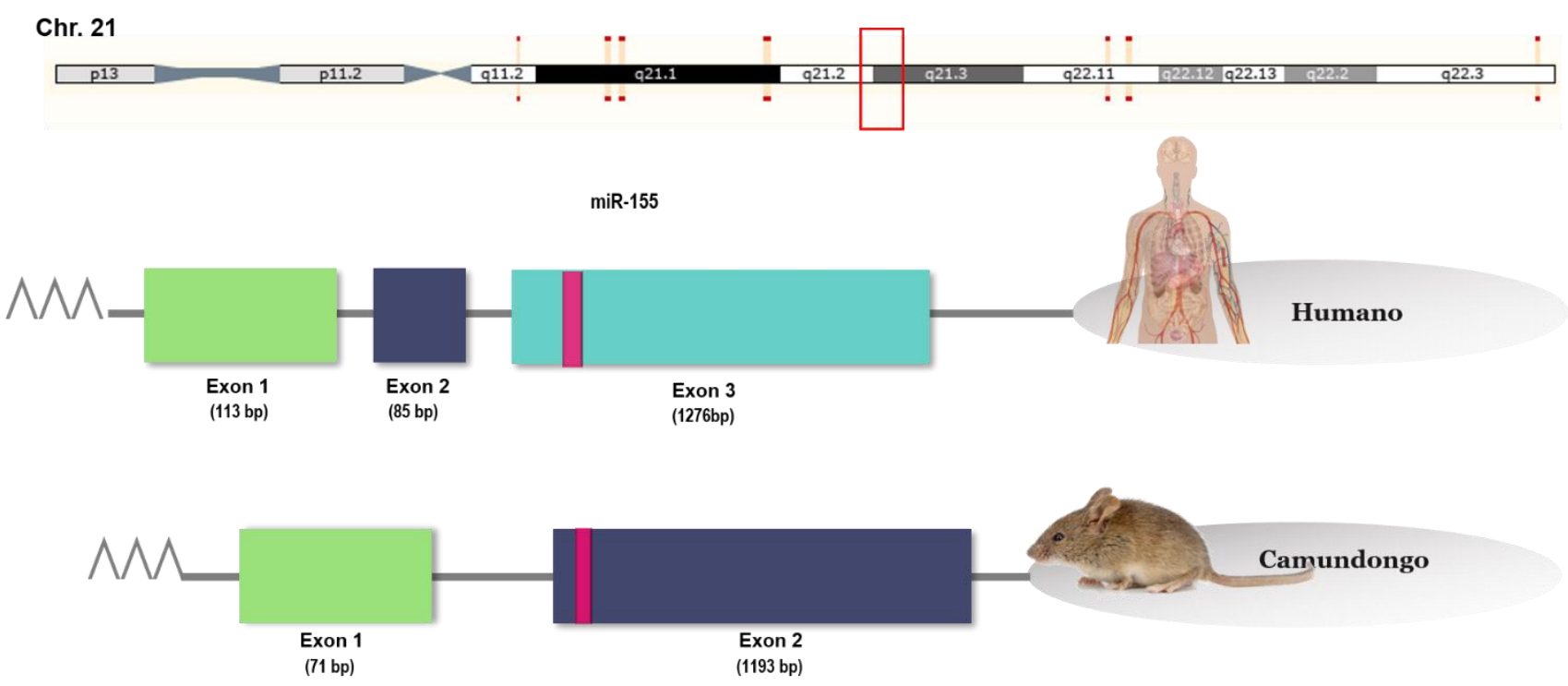

conrtis

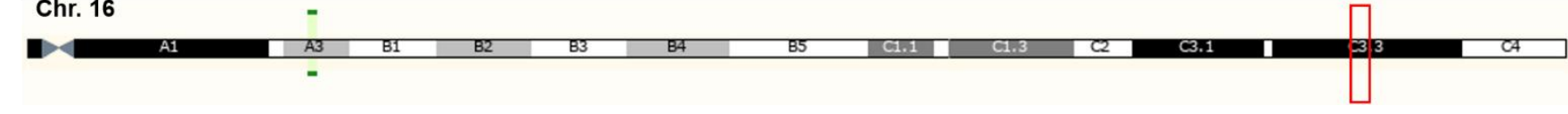

Figura 10. Representação da localização genômica do miR-155 em humanos e camundongos. Em humanos o MIR155HG está localizado no cromossomo 21, codificando um pri-miRNA de 1474 nt e possuindo 3 exons, com o miR-155 maduro localizado no exon 3 . Em camundongos o MIR155HG está localizado no cromossomo 16, codificando um pri-miRNA de $1264 \mathrm{nt} e$ possuindo 2 exons, com o miR-155 maduro localizado no exon 2 (www.ncbi.nlm.nih.gov/gene).

O papel do miR-155 já foi comprovado em diversas células do sistema imunológico (Figura 11) e sua expressão se faz necessária para manter a homeostase do sistema imunológico (RODRIGUEZ et al., 2007). Dudda e colaboradores (2013) demonstraram a importância do miR-155 na proliferação e sobrevivência de células $T$ CD8 ${ }^{+}$em resposta a infecções. 


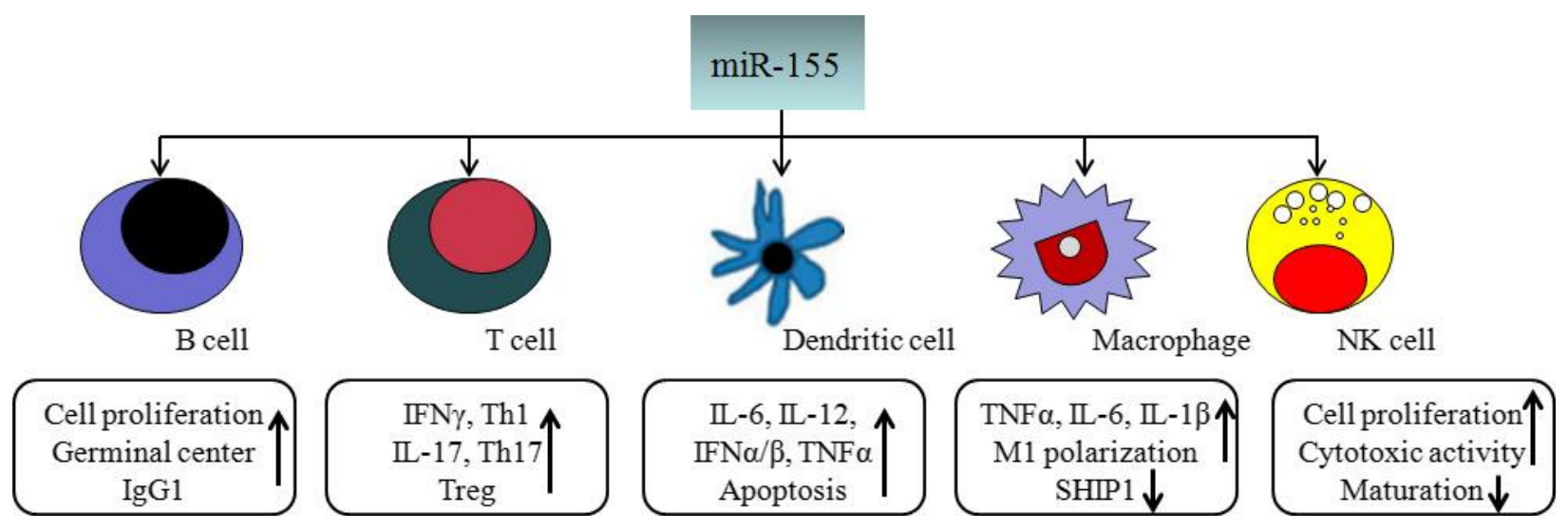

Figura 11. Papel do miR-155 em diferentes células do sistema imunológico. IgG, imunoglobulina G; IFN, interferon; Th, Célula T helper; IL, interleucinas; TNF, tumor necrosis factor (Su et al, 2017).

Mashima (2015) demonstrou que miR-155 tem sua expressão aumentada em macrófagos, células dendríticas e células $B$ e $T$ ativas. Também foi demonstrado a importância desse microRNA na proliferação e diferenciação de células $B$, além de contribuir para o desenvolvimento de células iNKT e Tregs (VIGORITO et al., 2007, BUROCCHI et al., 2015, KOHLHAAS et al., 2009).

O mmu-miR-155-5p possui a sequência UUAAUGCUAAUUGUGAUAGGGGU, e é predito pelo algorítimo do RNAhybrid (https://bibiserv2.cebitec.unibielefeld.de/rnahybrid) como um microRNA que tem Aire como alvo (Figura 12). Assim, sabendo da importância de Aire para a expressão gênica promiscua e do papel dos microRNAs no controle pós transcricional em diversos processos, em especial o papel do miR-155 no sistema imunológico, nos interessamos por esse microRNA para avaliar sua possível atuação no controle pós transcricional do próprio Aire e seu efeito no transcriptoma de células mTEC. O miR-155 foi selecionado baseando-se na predição in silico e em resultados preliminares, ainda não publicados, obtidos pelo nosso grupo. 
dataset: 1

target: NM_001271558.1:1306-1682

length: $37 \overline{7}$

miRNA : mmu-miR-155-5p

length: 23

$\mathrm{mfe}:-22.0 \mathrm{kcal} / \mathrm{mol}$

p-value: $1.000000 \mathrm{e}+00$

position 185

target $5^{\circ}$ A G UGA C $3^{\circ}$

GCCCC AUCG A GGCA

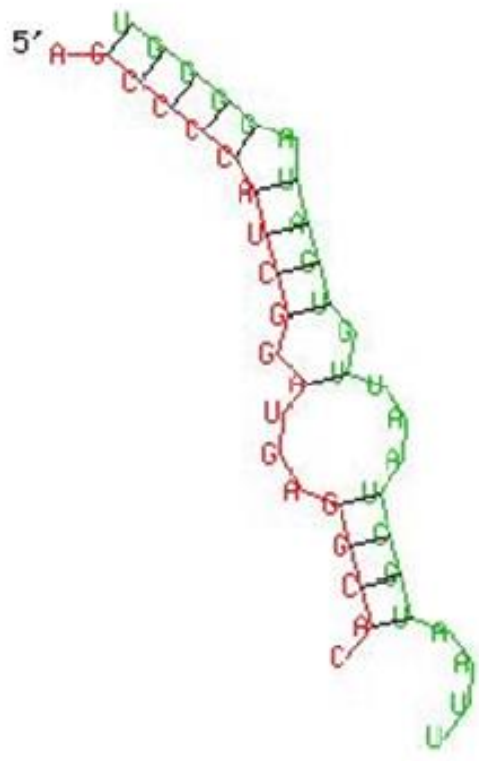

Figura 12. Predição in silico da interação entre miR-155 e a 3' UTR do mRNA de Aire. O algoritmo do RNAhybrid realiza a predição in silico de uma possível interação entre microRNAs. Neste caso, o miR-155 mostra interação com a 3' UTR do mRNA de Aire com energia livre de Gibbs de -22 kcal/mol (interação termodinamicamente estável). (Este trabalho). 
HIPÓTESE 


\section{Hipótese}

O microRNA 155 (miR-155) é um controlador pós-transcricional em células tímicas epiteliais medulares tendo a 3'UTR do mRNA do gene Aire como um de seus alvos além de modular a expressão de outros mRNAs. 
OBJETIVOS 


\section{Objetivos}

\subsection{Objetivo geral}

Estudar o controle pós-transcricional exercido pelo miR-155 em células tímicas epiteliais medulares focando sua interação com o mRNA de Aire. Além disso, estudar as consequências da ação deste microRNA no transcriptoma e numa propriedade biológica (quimiotaxia) de células mTEC in vitro.

\subsection{Objetivos específicos}

- $\quad$ Avaliar o efeito do miR-155 em células mTEC murinas in vitro sobre os seguintes aspectos:

- $\quad$ Os níveis do mRNA de Aire.

- $\quad$ Os níveis da proteína AIRE.

- O transcriptoma de mRNAs em geral.

- $\quad$ As propriedades quimiotáticas das células mTEC sobre timócitos (migração timócitos $\rightarrow$ mTECs). 
DELINEAMENTO EXPERIMENTAL 


\section{Delineamento experimental}

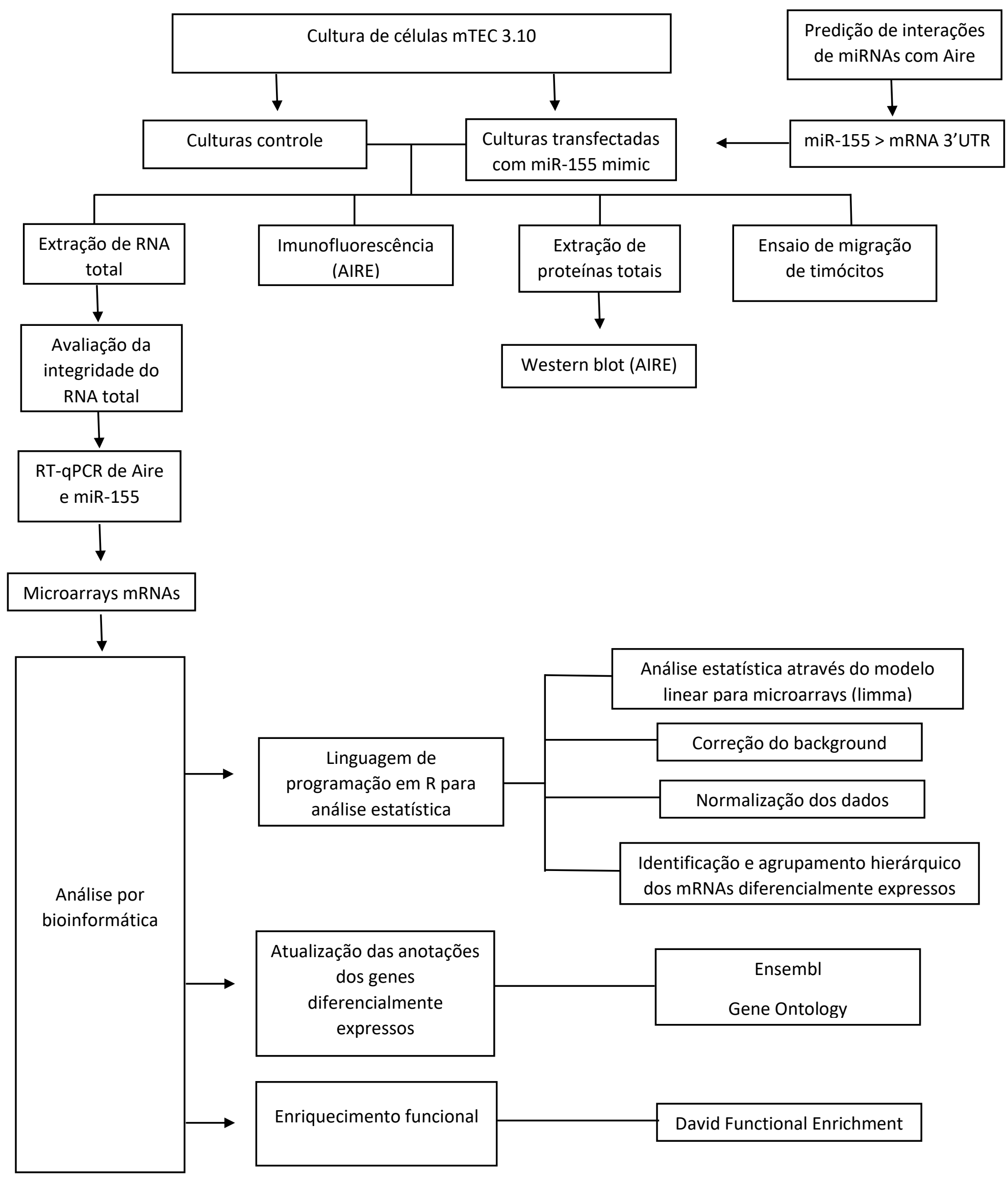




\section{Material e métodos}

\subsection{Predições das interações miR-155-mRNA in silico}

Para a análise de possíveis miRNAs que interagem com o mRNA de Aire, foi realizado uma busca nos bancos públicos de predição de interação de miRNA-mRNA utilizando-se da plataforma MirWalk disponível online em (http://zmf.umm.uniheidelberg.de/apps/zmf/mirwalk2/). Essa plataforma possui um algoritmo próprio para predições de interação miRNA-mRNA, mas também integra algoritmos de outros programas. A interação do miR-155 com a região 3'UTR do mRNA de Aire é predita com $\begin{array}{lllll}\text { com } & 0 & \text { uso } & \text { do } & \text { algoritmo }\end{array}$ (https://genie.weizmann.ac.il/pubs/mir07/mir07_prediction.html). A estabilidade termodinâmica da interação molecular foi então validada com o uso do algoritmo RNAhybrid (https://bibiserv2.cebitec.uni-bielefeld.de/rnahybrid) o qual analisa a estrutura secundária da interação e determina o sítio de hibridação mais favorável entre um determinado miRNA e a sequência exata da região 3'UTR de seu mRNA alvo. Só selecionamos interações com energia livre de Gibbs $\leq-20 \mathrm{kcal} / \mathrm{mol}$ que são as mais estáveis.

Os algoritmos da plataforma MirWalk (http://zmf.umm.uniheidelberg.de/apps/zmf/mirwalk2/) foram utilizados para a predição de outros mRNAs, além de Aire, que podem ser alvos do miR-155.

\subsection{Linhagem celular mTEC 3.10}

A linhagem primária de células tímicas epiteliais medulares (mTEC 3.10), utilizada neste trabalho, foi gentilmente cedida pelo Prof. Dr. Wilson Savino, então coordenador do Laboratório de Pesquisas sobre o Timo da Fundação Instituto Oswaldo Cruz (FIOCRUZ) do Rio de Janeiro, RJ.

As células mTEC 3.10 foram estabelecidas a partir do timo de camundongos recém-nascidos da linhagem C57BL/6 e fenotipadas como células Epcam+ Ly51-UEA1+ CD80 low $\mathrm{MHC}$-IIlow e que expressam o gene Autoimmune regulator (Aire) (Macedo et al., 2009, Pezzi et al., 2016). As células mTEC 3.10 são aderentes ao plástico poliestireno das garrafas de cultura e foram cultivadas em garrafas T25 $\left(25 \mathrm{~cm}^{2}\right)$ ou T75 $\left(75 \mathrm{~cm}^{2}\right)$ 
contendo, respectivamente, 5 e $10 \mathrm{~mL}$ de meio RPMI 1640 (Gibco - El Paso. TX, USA) suplementado com 10\% de soro fetal bovino (SFB) (Cultilab - Campinas, SP, Brasil), e mantidas a $37^{\circ} \mathrm{C}$ em estufa com atmosfera de $5 \%$ de $\mathrm{CO}_{2}$.

\subsection{Transfecção das células mTEC 3.10 com miRNA mimic}

Para a transfecção das células mTEC 3.10 com miR-155 mimic utilizamos aquele obtido da IDT (Integrated DNA Technologies, Coralville, lowa, USA) cuja sequência é: 5' UUAAUGCUAAUUGUGAUAGGGG 3'. As células foram transfectadas pelo método de lipofecção, com o uso do Lipofectin Reagent da Gibco-BRL Life Technologies (Van Allen Way Carlsbad, CA), seguindo o protocolo do fabricante. As células mTEC 3.10 foram cultivadas em garrafas T25 em condições convencionais de cultura até atingirem 50\% de confluência.

Quando a confluência desejada foi atingida procedeu-se a preparação do complexo miRNA-lipofectamina, $1 \mu \mathrm{L}$ de miR-155 mimic a $10 \mu \mathrm{M}$ foi gentilmente misturado à $500 \mu \mathrm{L}$ de Opti-MEM® I Reduced Serum Medium Gibco (Paisley, Scotland, UK) e após, foram adicionados $10 \mu \mathrm{l}$ de Lipofectin Reagent. Essa mistura foi vigorosamente agitada durante 10 segundos e em seguida, incubada por 10 minutos a temperatura ambiente.

O meio de cultura das garrafas foi trocado e foi então adicionado o complexo, totalizando o volume de $5 \mathrm{~mL}$ por garrafa e resultando na concentração de $2 \mathrm{nM}$ do miR155 mimic. Para o controle, foram cultivadas células simultaneamente e sob as mesmas condições, com exceção da adição do miR-155 mimic. As células foram mantidas em cultura por diferentes períodos contados em horas pós-transfecção (12, 24 e 48 h) em estufa a $37^{\circ} \mathrm{C}$ com $5 \%$ de $\mathrm{CO}_{2}$. Todos os pontos experimentais e controles foram repetidos em triplicata.

\subsection{Extração de RNA total}

A extração de RNA total foi realizada utilizando o kit mirVana miRNA Isolation Kit Ambion (Grand Island, NY, USA). Foram utilizadas para a extração de RNA total a linhagem de mTEC 3.10 das culturas controle e das culturas transfectadas. As células 
transfectadas e controles foram destacadas das garrafas de cultura por meio da adição de três $\mathrm{mL}$ de solução de tripsina/EDTA por 5 minutos. A tripsina foi inativada com meio de cultura contendo $10 \%$ de SFB, e as células colhidas por centrifugação a $1000 \times \mathrm{g}$ durante 5 minutos. O botão de células resultantes foi lavado duas vezes com PBS estéril e adicionamos $1 \mathrm{ml}$ de solução de lise. Agitou-se vigorosamente (1 minuto no vortex) para homogeneizar e lisar completamente as células. Adicionou-se $100 \mu \mathrm{l}$ de miRNA Homogenate Additive e misturou-se bem (vortex por 20 segundos).

A mistura foi deixada em banho de gelo por 10 minutos. Em seguida foi adicionado $1 \mathrm{~mL}$ de fenol ácido-clorofórmio, e a mistura foi agitada vigorosamente em vórtex por mais 1 minuto. $O$ lisado foi centrifugado a $10.000 \times \mathrm{g}$ por 5 minutos em temperatura ambiente. A fase aquosa foi cuidadosamente transferida para um novo tubo e então foi adicionado etanol $100 \%$ (pelo menos 1,25 vezes do volume da fase aquosa recuperado após a centrifugação) e à temperatura ambiente. Para cada amostra foi montada uma coluna com tubo coletor, adicionou-se $700 \mu \mathrm{L}$ da mistura (fase aquosa + etanol) nas colunas e as mesmas foram centrifugadas por 15 segundos a $10.000 \times \mathrm{g}$. O líquido foi descartado e o procedimento repetido até que toda a mistura fosse filtrada.

Por último, $700 \mu \mathrm{L}$ de miRNA Wash Solution 1 foram adicionados à coluna e centrifugado por 10 segundos a $10.000 \times$ g. O liquido foi descartado, e então $500 \mu \mathrm{L}$ de miRNA Wash Solution 2/3 foi aplicado na coluna e centrifugado por 10 segundos a 10.000 x g. O último passo foi repetido e, após descartar o liquido, o tubo foi centrifugado por 1 minuto para remover resíduos líquidos do filtro. A coluna foi transferida para um novo tubo coletor, e a ela foram adicionados $100 \mu \mathrm{L}$ de água MilliQ/DEPC pré-aquecida a $95^{\circ} \mathrm{C}$. O tubo foi centrifugado por 30 segundos para a recuperação do RNA total.

\subsection{Quantificação e avaliação do grau de pureza das amostras de RNA total}

A quantificação das amostras de RNA total foi realizada por espectrofotometria UV no aparelho NanoDrop ND-1000 (NanoDrop Products, Wilmington, DE, USA). Neste

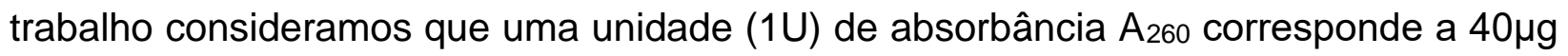
de $\mathrm{RNA} / \mathrm{mL}$. 
Além disso, avaliamos pureza das preparações por meio de cálculo das razões absorbância em diferentes comprimentos de onda de UV. Só utilizamos amostras livres de fenol que apresentaram razão $A_{260} / A_{230}$ entre 1.8 a 2.0 e livres de contaminação com proteínas razão $A_{260} / A_{280}$ entre 1.8 e 2.0 .

\subsection{Análise da integridade das preparações de RNA total}

A integridade do RNA total foi avaliada por eletroforese microfluídica através de RNA 6000 Nano chips e no aparelho Agilent 2100 Bioanalyzer® Agilent Technologies (Santa Clara, CA, USA).

Antes de iniciar o preparo do gel para a eletroforese, todos os reagentes, que anteriormente estavam a $4^{\circ} \mathrm{C}$, foram mantidos por 30 minutos a temperatura ambiente. Decorrido o tempo, iniciou-se o preparo do gel pipetando 550 $\mu \mathrm{L}$ do RNA $6000 \mathrm{Nano}$ gel em uma coluna com filtro e centrifugou-se a $1.500 \times \mathrm{g}$ durante 10 minutos em temperatura ambiente. Uma alíquota de $65 \mu$ foi colocada em um tubo de $0,5 \mathrm{~mL}$ livre de nucleases e em seguida, foi adicionado $1 \mu \mathrm{L}$ de RNA 6000 Nano Dye. A amostra foi submetida a agitação em vortex por 10 segundos, seguida de centrifugação a $13.000 \times$ g por 10 minutos em temperatura ambiente. Em seguida, iniciou-se o preparo do RNA 6000 Nano chip que foi colocado na priming station. Primeiramente foram pipetados $9 \mu \mathrm{l}$ da mistura gel/dye na região $G$ indicada no chip e com o auxílio de uma seringa acoplada à priming station o gel foi distribuído por todo o chip. Em seguida, outros $9 \mu \mathrm{l}$ da mistura foram pipetados nos demais pontos indicados com a letra $\mathrm{G}$.

Foram pipetados $5 \mu$ l do RNA 6000 Nano Marker em cada uma das amostras, bem como na posição do marcador e $1 \mu \mathrm{L}$ do marcador na posição indicada. Por último, pipetou-se $1 \mu \mathrm{l}$ de cada amostra de RNA nos respectivos poços marcados de 1 a $12 \mathrm{e}$ com a ajuda de um vortex IKA MS 3 (Manca, Hong Kong, CHN), agitou-se o chip horizontalmente a $2.200 \mathrm{rpm}$ por 1 minuto e em seguida, colocou-se o chip no bioanalisador para proceder-se a corrida eletroforética. O resultado das corridas foi obtido pelo Agilent 2100 Expert Software (eletroferograma e densitometria dos géis) após aproximadamente 30 minutos de corrida. Somente as amostras que apresentaram picos 
correspondentes aos padrões das espécies de RNAr 28S, 18S, 5S e RNAt 4S e com RNA Integrity Number $(\mathrm{RIN}) \geq 7.5$ foram utilizadas nos experimentos posteriores.

\subsection{Transcrição reversa para síntese do cDNA}

As reações de transcrição reversa de mRNAs foram realizadas com High Capacity cDNA Rverse Transcription Kit da Applied Biosystems ${ }^{\mathrm{TM}}$ (Foster City, CA) seguindo o protocolo do fabricante. Para isso, foi utilizado $500 \mathrm{ng}$ de RNA total.

Para a transcrição reversa do miR-155 foi utilizado o TaqMan MicroRNA Reverse Transcription Kit (Foster City, CA) seguindo o protocolo do fabricante. Para isso, foi utilizado 50 ng de RNA total.

\subsection{Confirmação da transcrição reversa}

\subsubsection{PCR convencional}

Um total de 200 ng de DNA total foi utilizado como input para uma reação de PCR convencional do mRNA (cDNA) de GAPDH para confirmar a reação de transcrição reversa. Os primers específicos foram F: 5' GGGTGTGAACCACGAGAAAT 3' e R: 5' CCTTCCACAATGCCAAAGTT3'. Uma mistura de DNA, primers a uma concentração final de $0.2 \mu \mathrm{M}$, dNTPs $(0.2 \mu \mathrm{M}), \mathrm{MgCl} 2(1,25 \mathrm{mM})$, Buffer (1x), e 1.25U da enzima Gotaq G2 Flexi DNA polimerase Promega (Wisconsin, USA) foi feita para um volume final de $25 \mu \mathrm{L}$. As amostrar foram amplificadas usando um termociclador GeneAmp PCR System 9700 (Applied Biosystem, Foster City, CA, USA) com o seguinte programa: Ativação da enzima a $95^{\circ} \mathrm{C}$ por 2 minutos e 30 ciclos de denaturação a $95^{\circ} \mathrm{C}$ por 20 segundos, pareamento dos primers a $60^{\circ} \mathrm{C}$ por 30 segundos e elongação da fita de DNA a $72^{\circ} \mathrm{C}$ por 30 segundos, um último passo de elongação foi feito a $72^{\circ} \mathrm{C}$ por 5 minutos.

\subsubsection{Eletroforese em gel de agarose}

Aos produtos da PCR foram adicionados $1 \mu \mathrm{L}$ de Gel Loading Buffer // da Ambion, e mais $1 \mu \mathrm{L}$ de solução diluída de brometo de etídeo. A eletroforese das amostras ocorreu em gel de agarose $2 \%(10 \times 7 \mathrm{~cm})$ por 1 hora a $100 \mathrm{~V}$. O tampão da cuba foi 0 1X TAE ( $\mathrm{pH}$ 8.6). O gel foi então visualizado sob luz ultravioleta de transiluminador e 
fotografado com auxílio do aparelho ImageQuant ${ }^{\mathrm{TM}}$ LAS 500 Ge Life Sciences (Piscataway, NJ, USA) para posterior análise das bandas.

\subsection{PCR quantitativa em tempo real (RT-qPCR)}

Os níveis de expressão do mRNA de Aire e do miR-155 foram avaliados por RTqPCR (Reverse Transcription Quantitative Real-Time Polymerase Chain Reaction).

Para isso foram adquiridas sondas TaqMan Gene Expression Assay para os genes Aire, GAPDH (controle endógeno para mRNA), microRNA-155 e snoRNA-202 (controle endógeno para microRNA). Foi utilizado o kit TaqMan Fast Advanced Master Mix (Foster City, CA) seguindo o protocolo do fabricante.

O nível de expressão do miR-155 foi normalizado através da expressão do snoRNA202, que é comumente utilizado como controle endógeno para análises de expressão de microRNAs.

A normalização dos níveis de expressão do gene Aire foi feita através da expressão do gene constitutivo GAPDH (ENSMUSG00000057666), o qual é normalmente utilizado com referência.

A quantificação relativa da expressão gênica foi determinada utilizando a método 2- $\Delta \Delta C T$ (Livak, 2001). Para análise estatística dos dados, foram utilizados os testes $t$ student e One-way ANOVA de acordo com a necessidade por meio do software estatístico GrapPad Prism.

\subsection{Extração das proteínas totais das células mTEC 3.10}

Para avaliar possíveis variações na quantidade da proteína AIRE, foi realizado o ensaio de Western Blot a partir das proteínas totais das culturas de células mTEC 3.10 controle ou transfectadas com miR-155 mimic. Aproximadamente $5 \times 10^{5}$ células foram semeadas em garrafas de cultura T 75 contendo $10 \mathrm{~mL}$ de meio RPMI 1640 e $10 \%$ de soro fetal bovino (SFB). As células foram transfectadas com miR-155 mimic e cultivadas durante 24,36 ou 48 horas.

As células foram destacadas das garrafas de cultura seguindo a inativação da tripsina com meio de cultura + SBF e colhidas por centrifugação a $1000 \times$ g durante 5 
minutos. As células foram lavadas três vezes com PBS 1x, e centrifugadas a $1000 \times \mathrm{g}$ durante 5 minutos. Foi então adicionado $300 \mu \mathrm{L}$ do tampão RIPA com inibidores de protease e as células foram lisadas com o auxílio de um homogeneizador Politron. $\mathrm{O}$ homogeneizado foi então centrifugado a $10.000 \times \mathrm{g}$ por 20 minutos e a $4^{\circ} \mathrm{C}$. O sobrenadante foi utilizado para quantificação das proteínas totais e para o experimento de Western Blot.

\subsection{Quantificação das proteínas totais}

Para a dosagem de proteínas totais foi utilizado o método de Bradford, que se baseia no deslocamento do pico de absorbância do corante Coomassie Blue G de 465 $\mathrm{nm}$ para $595 \mathrm{~nm}$ quando este se liga a proteínas em solução. O corante se liga principalmente ao resíduo de aminoácido arginina, mas também se liga a lisina, histidina, tirosina, triptofano e fenilalanima.

Vinte $\mu \mathrm{L}$ de amostras contendo proteínas, ou apenas tampão (para calibração do aparelho), foram colocadas em tubos de ensaio, foi então adicionado $1 \mathrm{~mL}$ do reagente de Bradford (BioRad, Hercules, CA, USA), seguido de agitação imediata. A leitura das amostras foi feita após 10 minutos utilizando-se cubetas de plástico num espectrofotômetro (Ultrospec Amersham Pharmacia) a $595 \mathrm{~nm}$. Uma curva padrão com soroalbumina bovina serviu de referência para estimarmos a concentração das proteínas totais.

\subsection{Western Blot}

A eletroforese de proteínas totais em gel desnaturante de poliacrilamida (SDSPAGE) foi realizada utilizando-se o sistema de tampão descontínuo descrito por Laemmli e Favre (1973). Foram utilizados mini-géis de poliacrilamida $(10 \times 8 \mathrm{~cm})$ e 0,075 cm de espessura. A concentração do gel de empilhamento foi $4 \%$ e do gel de separação foi $10 \%$. As amostras de proteína foram preparadas para eletroforese obedecendo a proporção de 3:1 (vol/vol), respectivamente, de amostra e tampão de amostra concentrado 4x (240 mM Tris- $\mathrm{HCl}$ pH 6,8; 8\% SDS; 40\% glicerol; 20\% 2-mercaptoetanol e azul de bromofenol). As amostras foram aquecidas por 5 minutos a $95^{\circ} \mathrm{C}$ em banho 
seco. O tampão dos eletrodos conteve $25 \mathrm{mM}$ Tris- $\mathrm{HCl}$, pH 8,3; $192 \mathrm{mM}$ glicina; 0,1\% SDS. O padrão de pesos moleculares de proteínas utilizado foi o Precision Plus Protein ${ }^{\mathrm{TM}}$ Dual Color Standards (BioRad, Hercules, CA, USA) exibindo bandas proteicas com os seguintes pesos moleculares em kDa: 250, 150, 100, 75, 50, 37, 25, 20, 15 e 10.

As bandas de proteínas, uma vez separadas, foram eletrotransferidas do gel para uma membrana de PVDF (BioRad, Hercules, CA, USA), utilizando-se como tampão de transferência $25 \mathrm{mM}$ Tris- $\mathrm{HCl}, 190 \mathrm{mM}$ glicina, 20\% metanol e $0,1 \%$ SDS a 80 volts por duas horas. Utilizamos para isso o aparelho Mini Trans-Blot $\AA$ Cell da BioRad (Hercules, CA, USA). Após a transferência, a membrana foi corada com $0,2 \%$ Ponceau $S$ em 3\% ácido tricloracético durante 5 minutos para observarmos a eficiência da transferência.

Em seguida, a membrana foi descorada com água deionizada. A imunomarcação da proteína de interesse (neste caso AIRE) iniciou-se com o bloqueio de locais inespecíficos da membrana com banho de leite desnatado (MOLICO), diluído a 5\% em TBS-Tween (50 mM Tris-HCl, pH 8,0; $150 \mathrm{mM} \mathrm{NaCl}$; 0,1\% Tween-20), por uma hora a temperatura ambiente. Após o bloqueio, a membrana foi incubada com o anticorpo primário policlonal Anti-Aire D17 (anticorpo de cabra) da Santa Cruz Biotechnology ${ }^{\circledR}$, Inc (Dallas, Texas, USA), diluído em TBS-T (1:500) overnight, que foi seguida de lavagens com TBS-T (vezes de 5 minutos).

A membrana foi incubada com o anticorpo secundário ( $\lg G$ anti-cabra) conjugado com peroxidase (horseradish-peroxidase - HRP), diluído 1:10.000 em TBS-T, por 1 hora. Após a incubação, fez-se novamente a lavagem da membrana em TBS-T, como anteriormente, e a revelação foi feita em aparelho ImageQuant ${ }^{\mathrm{TM}}$ LAS 500 Ge Life Sciences (Piscataway, NJ, USA), utilizando-se o substrato apropriado para a peroxidase (Luminata ${ }^{\mathrm{TM}}$ Forte, Merck Millipore). A reação foi conduzida protegida da luz e fizemos exposições da membrana em diferentes intervalos de tempo. A conversão da intensidade das imagens das bandas de proteína em valores numéricos foi feita com o auxílio do programa Image $\mathrm{J} 1.49$ (http://imagej.nih.gov/ij/index.html).

A proteína GAPDH (Glyceraldehyde 3-phosphate dehydrogenase) foi utilizada como normalizador nas análises, assim, a membrana também foi incubada com o anticorpo primário policlonal (de coelho) anti-GAPDH da Cell Signaling Technology (Beverly, MA, USA). Nesse caso, foi utilizado um anticorpo secundário lgG anti-coelho 
conjugado com peroxidase. O procedimento de marcação e revelação foi o mesmo utilizado para Aire.

\subsection{Ensaio de imunolocalização da proteína AIRE}

Ainda com a finalidade de avaliar variações na proteína AIRE, mas agora fazendo a sua localização intrecelular, utilizamos a técnica de imunolocalização (imunofluorescência) em células mTEC 3.10 controle ou transfectadas com miR-155 mimic. Para isso, utilizamos o anticorpo anti-AIRE D17 da Santa Cruz Biotechnology ${ }^{\circledR}$ (Dallas, Texas, USA). Para esse ensaio, foram plaqueadas $3 \times 10^{4}$ células mTEC $3.10 \mathrm{em}$ lamínulas de vidro de $13 \mathrm{~mm}^{2}$ dispostas sobre uma placa de 24 poços.

Decorrido os respectivos tempos após a transfecção com o mimic, o meio de cultura foi retirado dos poços e as lamínulas lavadas cinco vezes com PBS.

As células foram fixadas sobre as lamínulas com $300 \mu \mathrm{L}$ de paraformaldeído $4 \%$ em PBS durante15 minutos. Em seguida, as células foram submetidas a três lavagens de cinco minutos cada com PBS e, então, permeabilizadas com PBS contendo 0,5\% triton X-100 por cinco minutos.

Seguiram mais três lavagens com PBS (5 minutos cada), e as células foram bloqueadas por uma hora com 2\% BSA em PBS. O anticorpo primário (anti-AIRE D17) foi adicionado, diluído em PBS (1:50) contendo 1\% BSA e incubado por uma hora. Decorrido o tempo de incubação do anticorpo primário, as células foram lavadas com PBS por três vezes (10 minutos cada). Em seguida foi adicionado o anticorpo secundário Novex TM Mouse anti-Goat IgG $(H+L)$ Rhodamine Red Conjugate (Life Technologies Corporation, Carlsbad, CA, USA) diluído 1:500 em PBS contendo 1\% BSA durante uma hora. As lamínulas foram lavadas com PBS ( 3 x 10 min.).

Para a visualização da região citoplasmática, os filamentos de actina foram marcados com faloidina conjugada com AlexaFluor ${ }^{\circledR} 488$ Life TechnologiesTM (Eugene, Oregon, USA) conforme instruções do fabricante.

Por último, as lamínulas foram montadas com ProlongGold® Antifade Mountant (Life TechnologiesTM - Eugene, Oregon, USA) contendo DAPI (para visualização do 
núcleo). As lamínulas foram visualizadas em microscópio de fluorescência ApoTome Zeiss (Oberkochen, Germany).

\subsection{Avaliação do transcriptoma das células mTEC 3.10 transfectadas com miR-155 mimic}

Os microarrays Agilent $4 \times 44 \mathrm{~K}$ são preparados através do processo SurePrint (sistema de impressão), no qual 44.000 oligos são sintetizados na superfície de lâminas de vidro da dimensão de lâminas de microscópio previamente preparadas. Este processo de síntese in situ possibilita a montagem de oligonucleotídeos de 60-mer de comprimento, base a base, com extrema precisão utilizando arquivos de sequencias de mRNA baseado em bancos de dados. Nesses microarrays também estão presentes oligos que representam as isoformas de mRNAs e long-non-coding RNAs.

A amplificação e a marcação das amostras de RNA foram feitas com a utilização do Quick Amp Labeling Kit One-Color (cianina 3, cy3, verde) (Agilent Technologies, Santa Clara, CA, USA). O primeiro passo envolveu a diluição do Agilent One-Color SpikeMix. A solução foi aquecida a $37^{\circ} \mathrm{C}$ em banho-maria por 5 minutos, homogeneizada por meio de agitação em vortex e depois centrifugado brevemente antes do uso.

Em seguida, foram feitas diluições seriadas segundo recomendação do fabricante levando em consideração a quantidade inicial de RNA total. Para as amostras em questão optou-se pela massa de $500 \mathrm{ng}$ de RNA total. A primeira diluição (1:20) foi feita a partir de $2 \mu \mathrm{L}$ do Agilent One-Color Spike-Mix adicionados a $38 \mu \mathrm{L}$ do dilution buffer proveniente do kit. Após homogeneização no vórtex, retirou-se $2 \mu \mathrm{L}$ da primeira diluição e adicionou-se $48 \mu \mathrm{L}$ do dilution buffer obtendo-se assim a segunda diluição (1:25). A terceira diluição (1:10) foi preparada a partir de $4 \mu \mathrm{L}$ da segunda diluição adicionados a $36 \mu \mathrm{L}$ do dilution buffer.

Feitas as diluições, iniciou-se o protocolo de marcação das amostras adicionando $500 \mathrm{ng}$ de RNA total a um tubo de 1,5 mL e depois $1,2 \mu \mathrm{L}$ de T7 Promoter Primer em cada uma das amostras a serem marcadas. Em seguida, $5 \mu \mathrm{L}$ da terceira diluição do Agilent One-Color Spike-Mix foram adicionados com adição de água livre de nucleases para um volume final de $11,5 \mu \mathrm{L}$. As amostras foram então incubadas em banho-maria a 
$65^{\circ} \mathrm{C}$ por 10 minutos e posteriormente em gelo por 5 minutos. Durante o período de incubação um cDNA Master Mix (por lâmina) foi preparado a partir de $18 \mu \mathrm{L}$ do $5 \mathrm{X}$ first strand buffer (pré-aquecido a $80^{\circ} \mathrm{C}$ por 4 minutos), sendo adicionados $9 \mu \mathrm{L}$ de $0,1 \mathrm{M} \mathrm{DTT}$; 4,5 $\mu \mathrm{L}$ de $10 \mathrm{mM}$ dNTP mix; 4,5 $\mu \mathrm{L}$ MMLV-RT e 2,3 $\mu \mathrm{L}$ de RNaseOut sendo distribuído um volume de $8,5 \mu \mathrm{L}$ do mix em cada tubo de amostra. Após homogeneização as amostras foram incubadas a $40^{\circ} \mathrm{C}$ em um banho-maria por 2 horas.

Ao final deste período de incubação, as amostras foram removidas para banhomaria a $65^{\circ} \mathrm{C}$, incubadas por 15 minutos e posteriormente removidas para o gelo permanecendo incubadas por mais 5 minutos.

Imediatamente antes do uso foi preparado um transcription master mix (por lâmina) a partir de $68,9 \mu \mathrm{L}$ de água livre de nucleases; $90 \mu \mathrm{L}$ de $4 \mathrm{X}$ transcription buffer; $27 \mu \mathrm{L}$ de $0,1 \mathrm{M}$ DTT; $36 \mu \mathrm{L}$ de NTP mix; $28,8 \mu \mathrm{L}$ de $50 \%$ PEG (pré-aquecido a $40^{\circ} \mathrm{C}$ por 1 minuto); $2,3 \mu \mathrm{L}$ de RNaseOut; $2,7 \mu \mathrm{L}$ de inorganic pyrophosphatase; 3,6 $\mu \mathrm{L}$ de T7 RNA polymerase e $10,8 \mu \mathrm{L}$ de Cy3-CTP. Cada tubo de amostra recebeu $60 \mu \mathrm{L}$ transcription master mix e após homogeneização foram incubados a $40^{\circ} \mathrm{C}$ em um banho-maria por 2 horas.

O passo que sucede a incubação envolve a purificação do RNA amplificado e marcado. Para tal procedimento foi utilizado o Illustra RNAspin Mini RNA Isolation Kit (GE Healthcare, Little Chalfont, Buckinghamshire, UK). Um passo inicial de limpeza do RNA foi realizado adicionando $3,5 \mathrm{X}$ o volume da reação $(280 \mu \mathrm{L})$ do tampão RA1 em cada amostra. Em seguida a cada tubo foram adicionados $280 \mu \mathrm{L}$ de etanol $100 \%$ (equivalente também a 3,5X o volume da reação) com posterior homogeneização.

A purificação do RNA foi realizada através de colunas RNAspin Mini aplicando o volume total de cada amostra na coluna seguida de centrifugação de 30 segundos a $8.000 \times$ g. Cada coluna foi então transferida para outro tubo coletor. Os passos de dessalinização da membrana sílica, digestão do DNA, lavagem e secagem da membrana sílica recomendados pelo kit não foram utilizados. A purificação foi retomada a partir da segunda lavagem aplicando-se o tampão RA3 em cada coluna seguida de uma centrifugação de 1 minuto. O líquido foi descartado e a coluna foi posta novamente no tubo para uma terceira lavagem aplicando-se $250 \mu \mathrm{L}$ do tampão RA3, seguida de centrifugação por 2 minutos. 
O último passo do protocolo envolveu a eluição do RNA em alta concentração adicionando-se $40 \mu \mathrm{L}$ de água livre de nucleases seguido de centrifugação por 1 minuto a $11.000 \times$ g. Em seguida o RNA foi quantificado num espectrofotômetro NanoDrop ND1000 UV-VIS espectrofotômetro (NanoDrop Technologies). Além disso, foi detectada a incorporação do fluorocromo cianina (Cy3) nas amostras expressando sua concentração em pmol/ $\mu \mathrm{L}$. O valor da incorporação total dividido pela massa total fornece um valor que serve como referência para o prosseguimento do passo de hibridação. Somente as amostras que obtiveram os valores acima de 9 foram utilizadas.

Anterior ao passo de hibridação, as amostras passaram por um processo de fragmentação utilizando o fragmentation mix para $4 \times 44 \mathrm{~K}$ microarrays. Cada amostra contendo 1,65 $\mu \mathrm{g}$ de RNA marcado e amplificado (cRNA) recebeu $11 \mu \mathrm{L}$ de $10 \mathrm{X}$ blocking agent (preparado com a adição de $500 \mu \mathrm{L}$ de água livre de nucleases e aquecido a $37^{\circ} \mathrm{C}$ por 4 minutos). Nesse momento o volume da reação não deve ser superior a $52,8 \mu \mathrm{L}$ sendo necessário completar cada amostra com o volume de água livre de nucleases correspondente. Por último adicionou-se $2,2 \mu \mathrm{L}$ de $25 \mathrm{X}$ fragmentation buffer em cada tubo sendo o volume final da reação de $55 \mu \mathrm{L}$. Em seguida as amostras foram incubadas em banho-maria a $60^{\circ} \mathrm{C}$ por 30 minutos.

Após a incubação, seguindo a recomendação do kit para lâminas de microarrays 4x44K, adicionou-se 55 $\mu \mathrm{L}$ do 2 X GE Hybridization Buffer HI-RPM em cada tubo e após homogeneização as amostras foram centrifugadas por 1 minuto a $13.000 \mathrm{~g}$. Um volume de $100 \mu \mathrm{L}$ de cada amostra foi utilizada imediatamente para o processo de hibridação no forno a $65^{\circ} \mathrm{C}$ em rotação durante 17 horas.

Após a hibridação, as lâminas passaram por um processo de lavagem na seguinte ordem: tampão 1 (GE Wash Buffer 1 - 0,005\% Triton X-102) por 1 minuto à temperatura ambiente, tampão 2 (GE Wash Buffer 2 - 0,005\% Triton X-102) por 1 minuto a $37^{\circ} \mathrm{C}$. Ambas as lavagens foram feitas em um agitador com o uso de barras magnéticas. Em seguida as lâminas foram colocadas em solução de acetonitrila por 10 segundos à temperatura ambiente e por último na solução Stabilization and Drying por 30 segundos a temperatura ambiente capaz de prevenir a degradação da Cianina 3 (Сy3) pelo ozônio.

Após serem retiradas da solução, as lâminas foram escaneadas imediatamente evitando o impacto dos oxidantes ambientais na intensidade dos sinais utilizando o DNA 
Microarray Scanner (Agilent Technologies) e os dados foram extraídos através do Agilent Feature Extraction Software. Os dados brutos foram então depositados no banco de dados ArrayExpress no EMBL-EBI (www.ebi.ac.uk/arrayexpress) sob o número de acesso E-MTAB7709.

\subsection{Análises dos dados de microarrays por bioinformática}

Os valores numéricos quantitativos foram então analisados no ambiente $R$ (versão 3.3.2 - R Development Core Team, 2011, disponível em "R Project for Statistical Computing" (https://www.r-project.org/). A "plataforma R" consiste em um ambiente estatístico-matemático que permite a execução de múltiplas funções, sendo amplamente empregado em análise de dados de microarrays, permitindo ainda execução de cálculos e visualização gráfica dos resultados.

Foram eliminados os dados cujos valores sobrepuseram os valores de background (correção do background ou signal-background). A fim de remover as variações não biológicas capazes de afetar as medições dos níveis de expressão gênica para tornar os dados comparáveis, realizamos a normalização dos dados. A normalização foi realizada pela metodologia quantile, método considerado robusto que corrige as diferenças nas densidades de probabilidade de todas as amostras (GALLÓN; LOUBES; MAZA, 2013).

Para análise dos transcritos diferencialmente expressos utilizamos as funções do pacote Limma (Linear Models for Microarray Data) (RITCHIE et al., 2007, 2015), o qual aplica um modelo linear na análise estatística e reajusta os erros padrão segundo um modelo Bayesiano (Empirical Bayes e outros métodos), usado para interrogar informações da atividade de genes por meio de análises estáveis, mesmo para experimentos com pequeno número de matrizes. O método de Benjamini Hochberg foi aplicado para a correção (BENJAMINI e HOCHBERG, 1995). 


\subsection{Separação de timócitos}

Para a separação de timócitos, camundongos C57BL/6 fêmeas com de 5-6 semanas de idade foram mortos em câmara de $\mathrm{CO}_{2}$ e os timos desses animais foram rapidamente removidos por cirurgia torácica. Os órgãos foram pinçados em meio de cultura RPMI 1640 numa placa de Petri. Os timócitos foram separados pela passagem da suspensão celular através de uma membrana de nylon (Sefar Inc. Depew, NY, USA) com porosidade de $10 \mu \mathrm{m}$. A suspensão de timócitos foi centrifugada por 5 minutos a 1000 x g e as células foram lavadas duas vezes com PBS e então ressuspendidas em meio RPMI 1640.

\subsection{Ensaio de migração celular}

Para o ensaio de migração dos timócitos em câmaras transwell, insertos de 6.5 $\mathrm{mm}$ com membrana de policarbonato de $0.5 \mu \mathrm{m}$ (Corning Inc. Corning, NY) foram colocados em placas de 24 poços e incubados em PBS por 1 hora a $37^{\circ} \mathrm{C}$, após 1 hora os insertos foram bloqueados em PBS contendo $10 \mu \mathrm{g}$ de BSA $/ \mathrm{mL}$ por 1 minuto.

Esses insertos foram então transferidos para poços contendo meio de cultura "condicionado", ou seja, meio recolhido de cultura de células mTEC 3.10 controle ou mTEC 3.10 transfectadas com miR-155 mimic (culturas de 24 horas). O meio condicionado era filtrado em filtros $0.45 \mu$ antes da utilização. Cem microlitros desse tipo de meio foram colocados em cada poço da placa. Logo em seguida despejamos uma suspensão contendo $2.5 \times 10^{6}$ timócitos em cada um dos insertos, que foram então acondicionados dentro dos poços e então as placas foram incubadas em estufa a $37^{\circ} \mathrm{C}$ e $5 \% \mathrm{CO}_{2}$ por 3 horas para permitir a migração dos timócitos.

Os insertos foram então colocados em poços contendo etanol $70 \%$ por 10 minutos para fixar os timócitos que estavam no processo de atravessar os poros. Depois coramos a superfície externa de cada inserto com Giemsa por 10 minutos e finalmente lavadas em água deionizada para retirar o excesso de corante e então deixados para secar ao ar ambiente. Os insertos foram visualizados e fotografados num estereomicroscópio modelo Stemi 508 Zeiss (Oberkochen, Germany). 
RESULTADOS 


\section{Resultados}

\subsection{Quantificação do miR-155 por RT-qPCR}

Para avaliar o possível efeito do miR-155 sobre o mRNA de Aire, as células mTEC 3.10 foram transfectadas com miR-155 mimic. Foram então realizadas reações de RTqPCR desse microRNA para confirmar o sucesso da transfecção e avaliar os seus níveis intracelulares com 12, 24 e 48 horas após a transfecção.

O tempo de 12 horas após a transfecção mostrou o maior nível intracelular do miR-155 em comparação com seus níveis nas células controle. Todos os controles apresentam o mesmo nível de expressão, como esperado. No tempo de 24 horas a expressão do miR-155 já era bastante reduzida, sem apresentar uma diferença estatisticamente significativa com relação ao controle. Isso nos mostrou que o tempo de 12 horas após a transfecção é o período mais adequado para se avaliar o efeito do aumento dos níveis do miR-155 nas células mTEC 3.10 .

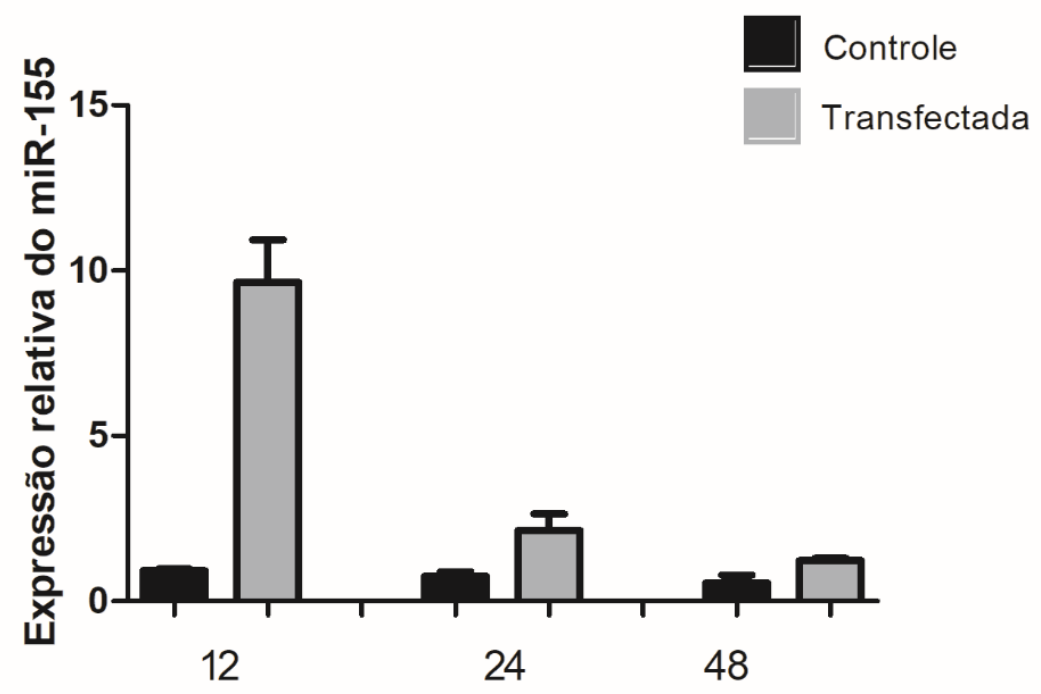

Horas

Figura 13. Avaliação temporal dos níveis do miR-155 após transfecção do mimic. As células mTEC 3.10 foram transfectadas com miR-155 mimic e os controles foram cultivados nas mesmas condições, porém na ausência do mimic. O maior nível de expressão do miR-155 foi observado 12 horas após a transfecção. Teste t-student. $p=0.0025$. No tempo de 24 horas não há mais uma diferença significativa entre as culturas controle e transfectadas. One-way ANOVA $\mathrm{p}<$ 0.0001 . 


\subsection{Quantificação da expressão relativa do mRNA de Aire por RT-qPCR}

Após a confirmação da transfecção do miR-155 mimic, foi feita a RT-qPCR do mRNA (cDNA) de Aire nos tempos de 12, 24 e 48 horas (após a transfecção).

Os resultados mostraram redução significativa na expressão do mRNA de Aire 12 horas após o pico do nível de expressão do miR-155, ou seja, 24 horas após a transfecção. Após 48 horas da transfecção, a expressão de Aire já volta aos níveis normais.

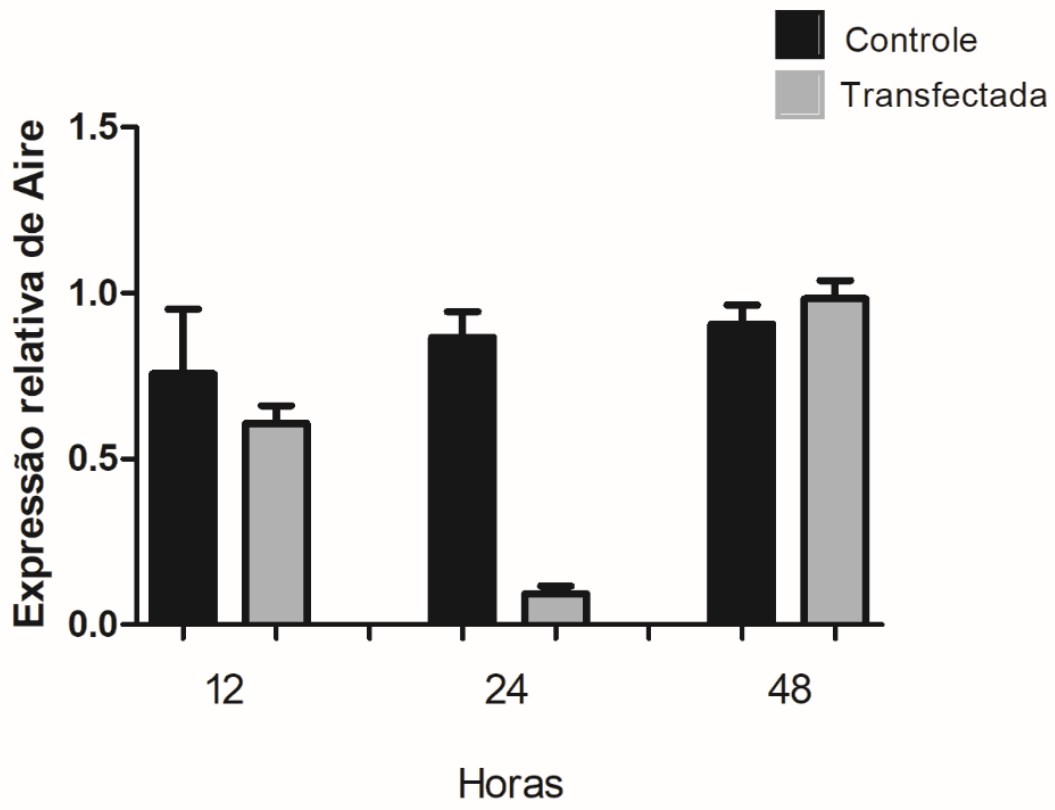

Figura 14. Avaliação temporal dos níveis de expressão do mRNA de Aire após transfecção do miR-155 mimic. As células mTEC 3.10 foram transfectadas com miR-155 mimic (controle são as culturas sem mimic). A maior redução nos níveis de expressão do Aire mRNA foi observada 24 horas após a transfecção. Teste t-student. $p=0.0007$. One-way ANOVA $p=0.0003$.

\subsection{Análise da expressão da proteína AIRE por Western Blot}

Os resultados obtidos por qPCR mostraram que os níveis de mRNA de Aire apresenta decaimento máximo 24 horas após a transfecção com o miR-155 mimic. 
Portanto, decidimos avaliar os níveis da proteína AIRE por western blot após decorrer esse período de tempo.

A expressão da proteína AIRE se mostrou reduzida (redução média de 37.3\%) 24 horas após a transfecção com o miR-155 mimic e retornando a níveis normais após 48 horas (Figura 15).
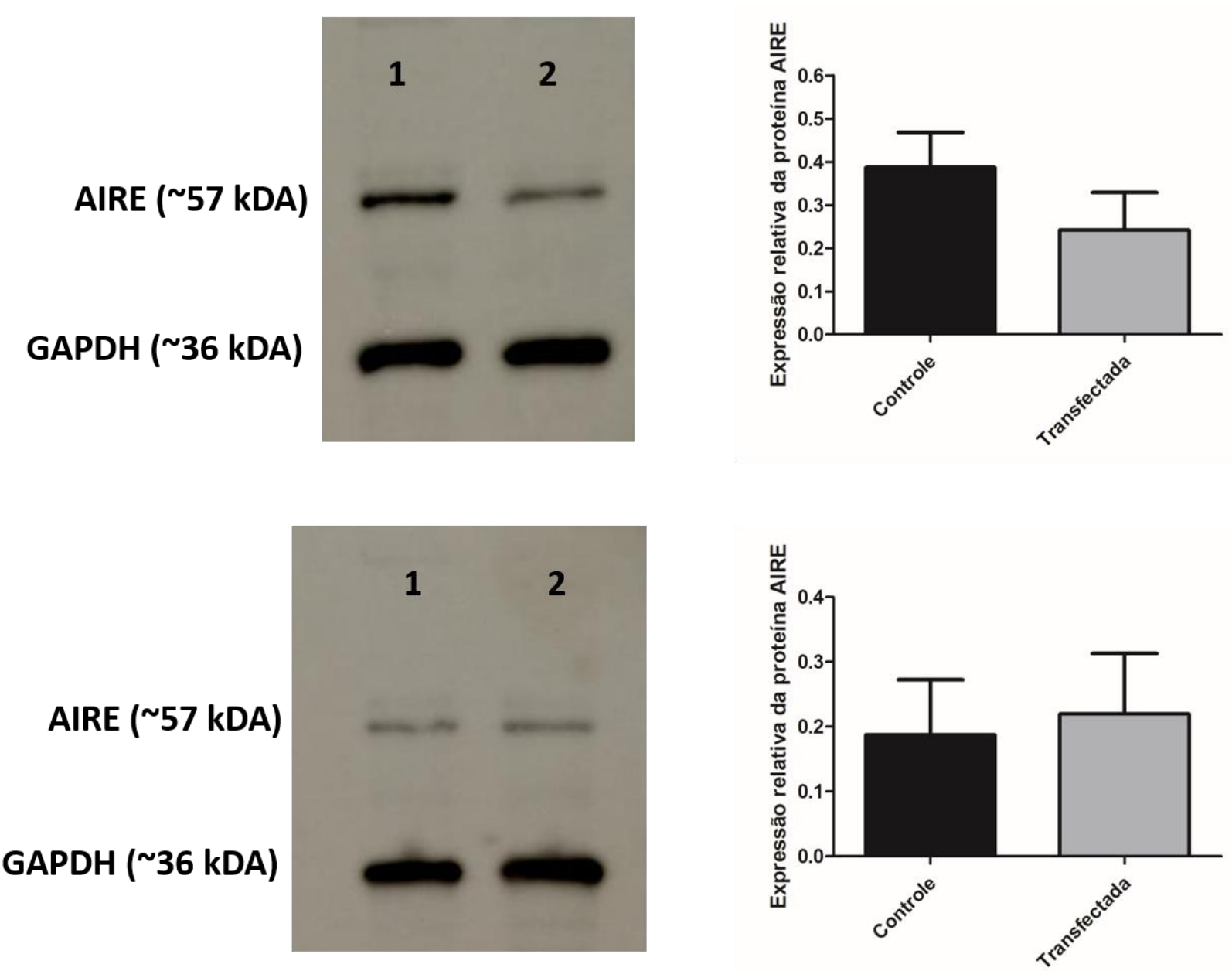

Figura 15. Western Blot da proteína AIRE. (A) Detecção da proteína AIRE ( 57kDa) e GAPDH ( $36 \mathrm{kDa})$, essa utilizada como normalizador, nas amostras de proteína total extraída de células mTEC 3.10 controle (1) e após a transfecção com miR-155 mimic (2), no tempo de 24 horas. Observa-se redução média de $37.3 \%$ de AIRE. Test t-student $p=0.023$. (B) Detecção da proteína AIRE ( $\sim 57 \mathrm{kDa})$ e GAPDH ( 36 kDa), utilizada como normalizador, nas amostras de proteínas totais extraídas de células mTEC 3.10 controle (1) e após a transfecção com miR-155 mimic (2), no tempo de 48 horas. O nível de expressão de AIRE já não apresenta diferença entra as células controle e as células transfectadas após 48 horas da transfecção. 


\subsection{Análise da expressão da proteína AIRE por imunofluorescência}

Ainda com a intenção de se avaliar os efeitos da transfecção do miR-155 mimic sobre a proteína AIRE, mas dessa vez preservando as estruturas celulares, foi realizado o ensaio de imunofluorescência. Dessa vez, fizemos observações nos tempos de 24, 36 e 48 horas após a transfecção. $O$ ensaio de imunofluorescência possibilitou avaliar se 0 miR-155 afeta tanto a intensidade de expressão da proteína AIRE como também o número de células $A I R E^{+}$numa população.

A proteína AIRE é geralmente visualizada como pontos (pontos vermelhos nesse caso) em sua maioria no núcleo, já que ela atua junto a cromatina. Nas células mTEC 3.10 transfectadas com miR-155 mimic foi possível observar redução de aprox. 15.2\% na intensidade do sinal de AIRE após 24 horas da transfecção (Figura 16). Também foi possível notar que o miR-155 mimic afetou mais a intensidade da proteína, já que não houve redução no número de células Aire ${ }^{+}$. Isso quer dizer que o número de células Aire ${ }^{+}$ no controle e nos experimentos (transfectados) foi o mesmo, mas a intensidade de sua expressão em cada célula se mostrou reduzida. 

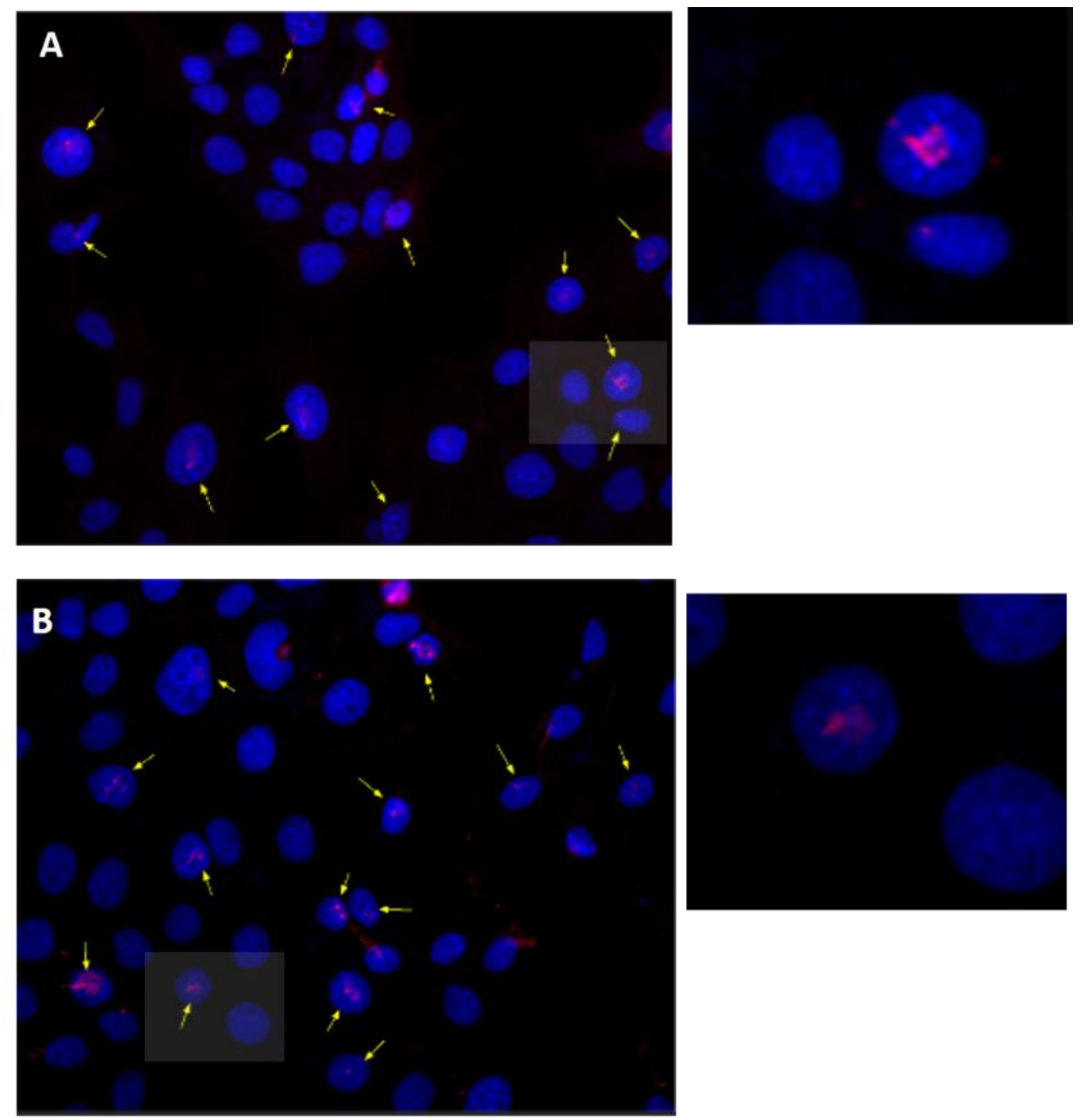

Figura 16. Imunofluorescência da proteína AIRE. A proteína AIRE foi marcada com o anticorpo primário anti-Aire D17 conjugado com anticorpo secundário marcado com rodamina (vermelho) e o núcleo foi corado com DAPI. (A) Células mTEC 3.10 controles. (B) Células mTEC 3.10 transfectadas com miR-155 mimic e observadas após 24 horas. É possível notar redução na intensidade do sinal de AIRE nas células transfectadas.

\subsection{Análise dos mRNAs diferencialmente expressos em células mTEC 3.10} transfectadas com miR-155 mimic

As células transfectadas com o miR-155 mimic (24 horas após a transfecção) apresentaram seu maior efeito sobre o mRNA de Aire e sua proteína. Portanto, esse tipo de amostra foi selecionado para as análises de expressão gênica em grande escala (transcriptoma) através da técnica de dos microarrays e o pacote de modelo linear limma. 
Os mRNAs foram considerados como diferencialmente expressos quando apresentavam um fold change $\geq 1.5$. Como cuttoff foi utilizado um valor de $p$ ajustado $\leq 0.05$ (BenjaminiHochberg FDR).

Os mRNAs diferencialmente expressos foram então agrupados em um heatmap (Figura 17). No total 311 mRNAs tiveram suas expressões alteradas, desses, 103 foram super-regulados e 208 foram sub-regulados (Apêndice 1). Desses 311 mRNAs 249 codificam proteínas já descritas, enquanto que os outros 62 correspondem a genes/mRNAs preditos e que até a conclusão dessas análises (Janeiro/2019) ainda não possuíam anotação em bancos de dados públicos.
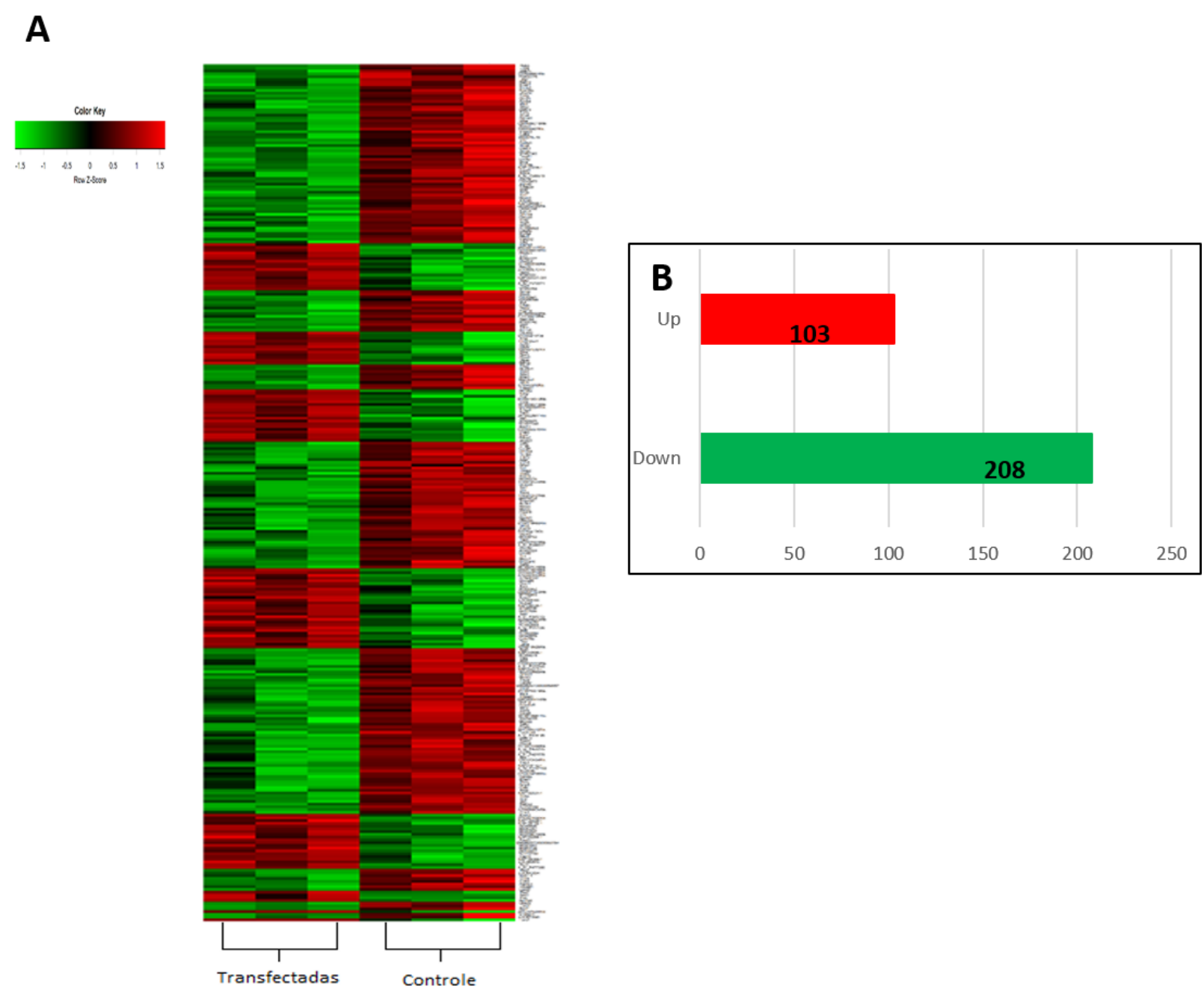

Figura 17. Perfil de expressão dos mRNAs diferencialmente expressos. (A) $O$ heatmap evidencia o agrupamento hierárquico dos 311 mRNAs modulados nas células mTEC 3.10 transfectadas com miR-155 mimic em comparação com as células mTEC 3.10 controle. (B) dos 311 mRNAs diferencialmente expressos, 103 foram super-regulados e 208 foram sub-regulados. 
Tabela 1. Top mRNAs diferencialmente expressos em células mTECs 3.10 transfectadas com miR-155 mimic. Apenas genes/mRNAs com anotação nos bancos de dados foram considerados.

\begin{tabular}{|c|c|c|c|}
\hline \multicolumn{2}{|c|}{ Top 10 mRNAs super-expressos } & \multicolumn{2}{c|}{ Top 10 mRNAs sub-expressos } \\
\hline Nome & Fold change & Nome & Fold change \\
\hline Lars2 & 12.34745 & Bcas1 & 2.983013 \\
\hline Lalba & 3.44062 & Hnrpl & 2.973211 \\
\hline Rmrp & 3.036282 & Heatr3 & 2.536115 \\
\hline Paqr3 & 3.026607 & Nlrp2 & 2.373542 \\
\hline Tsix & 2.913183 & Alpi & 2.366964 \\
\hline Mdfi & 2.531977 & Cldn6 & 2.31726 \\
\hline Drd3 & 2.363583 & Defb15 & 2.302753 \\
\hline Expi & 2.094296 & Pnmt & 2.25615 \\
\hline Bach1 & 2.031842 & Tmc1 & 2.256076 \\
\hline P4ha2 & 2.02822 & Spnb4 & 2.254812 \\
\hline
\end{tabular}

Dos 249 mRNAs modulados e que possuem anotação, 58 (23.3 \%) são considerados como codificadores de TRAs, ou seja, possuem sua expressão aumentada, em relação à média, em no máximo 5 tecidos (Sansom et al 2014) (Apêndice 2).

Se faz necessário considerar que os microRNAs, por serem pequenos ( 22 nt), possuem vários alvos. Portanto, nesse trabalho avaliamos quais dos mRNAs modulados poderiam ser alvos do miR-155 de acordo com as predições do MirWalk (Tabela 2). 
Tabela 2. mRNAs preditos (MirWalk) como possíveis alvos do miR-155

\begin{tabular}{|l|l|}
\hline \multicolumn{2}{|c|}{ mRNAs preditos como possíveis alvos do miR-155 } \\
\hline 2010107E04Rik & Hapln3 \\
\hline 2310079G19Rik & Kpna4 \\
\hline 4930519N16Rik & Mccc2 \\
\hline Ampd3 & Ndn \\
\hline Bach1 & Prkci \\
\hline Cycs & Rreb1 \\
\hline Dbn1 & Snrpn \\
\hline Gbe1 & \\
\hline
\end{tabular}

\subsection{Análise do enriquecimento funcional dos mRNAs}

Com o objetivo de identificar o efeito do miR-155 nas células mTEC 3.10 foi realizado, através da plataforma DAVID, a predição in silico da função dos mRNAs diferencialmente expressos. Inicialmente, os mRNAs foram separados em dois grupos, os super-expressos e os sub-expressos e depois foram agrupados em relação as suas funções em processos biológicos, componentes celulares ou função molecular. Foram consideradas categorias que agruparam ao menos três mRNAs e um score $<0.05 \mathrm{com}$ correção de Benjamini-Hochberg (Figuras 17 e 18). 
A

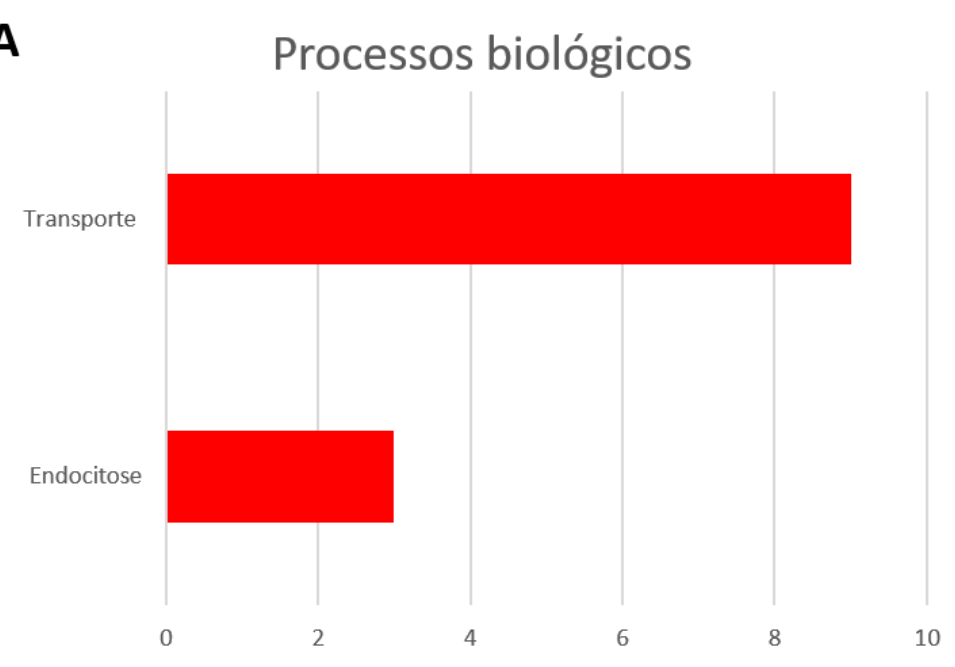

B Componentes celulares

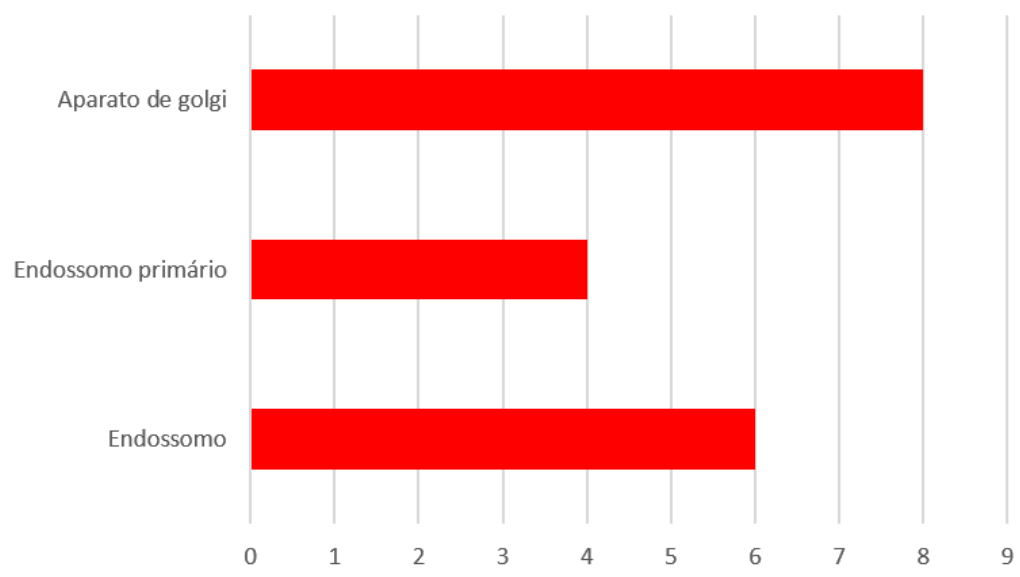

C

Funções moleculares

Ligação de proteínas identicas

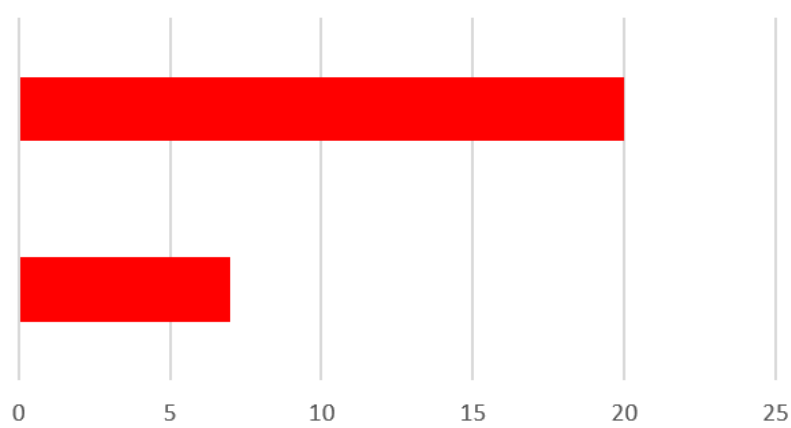

Figura 17. Enriquecimento funcional dos mRNAs super-regulados (Plataforma DAVID Bioinformatics Resources 6.8 Database, score < 0,05). (A) processos biológicos, (B) componentes celulares e (C) Funções moleculares. 
A

Processos biológicos

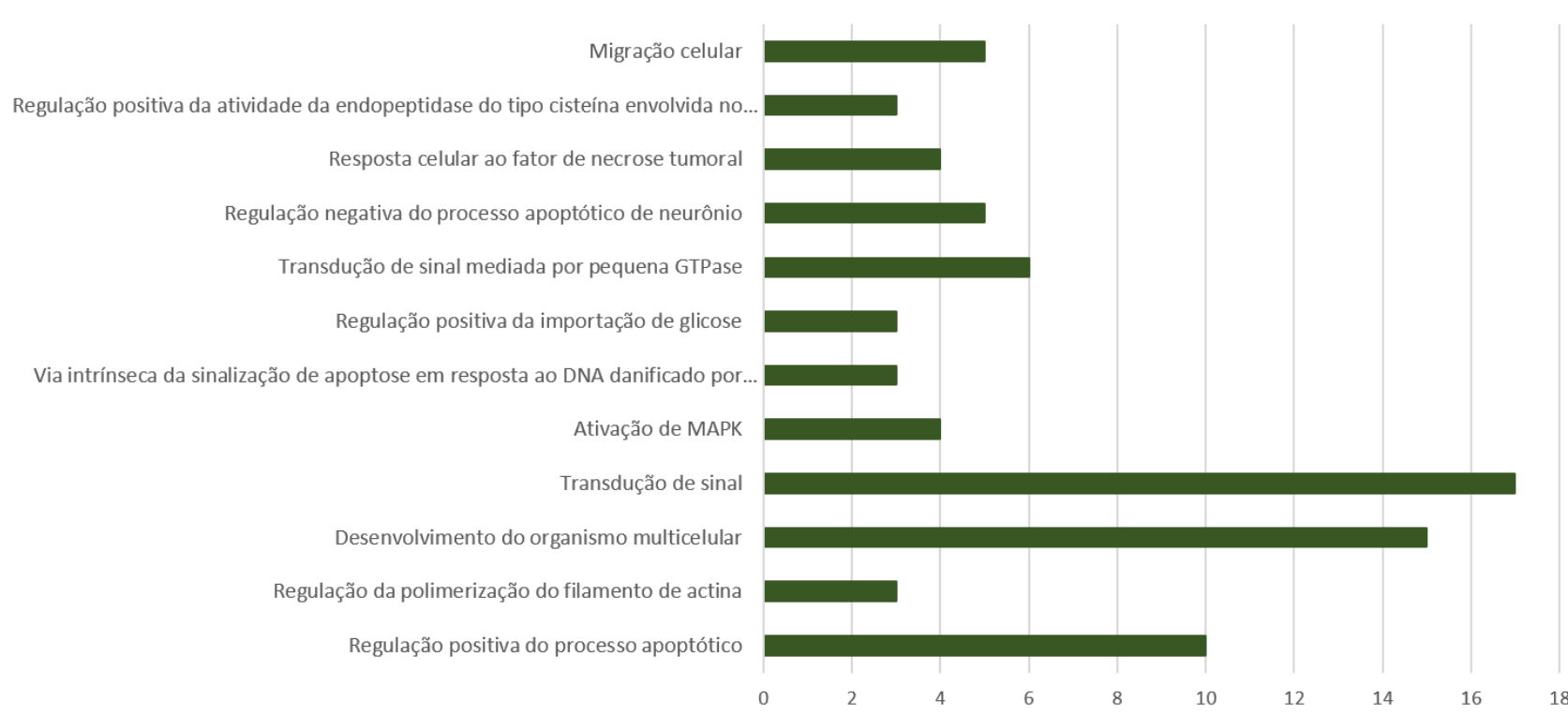

B

Componentes celulares
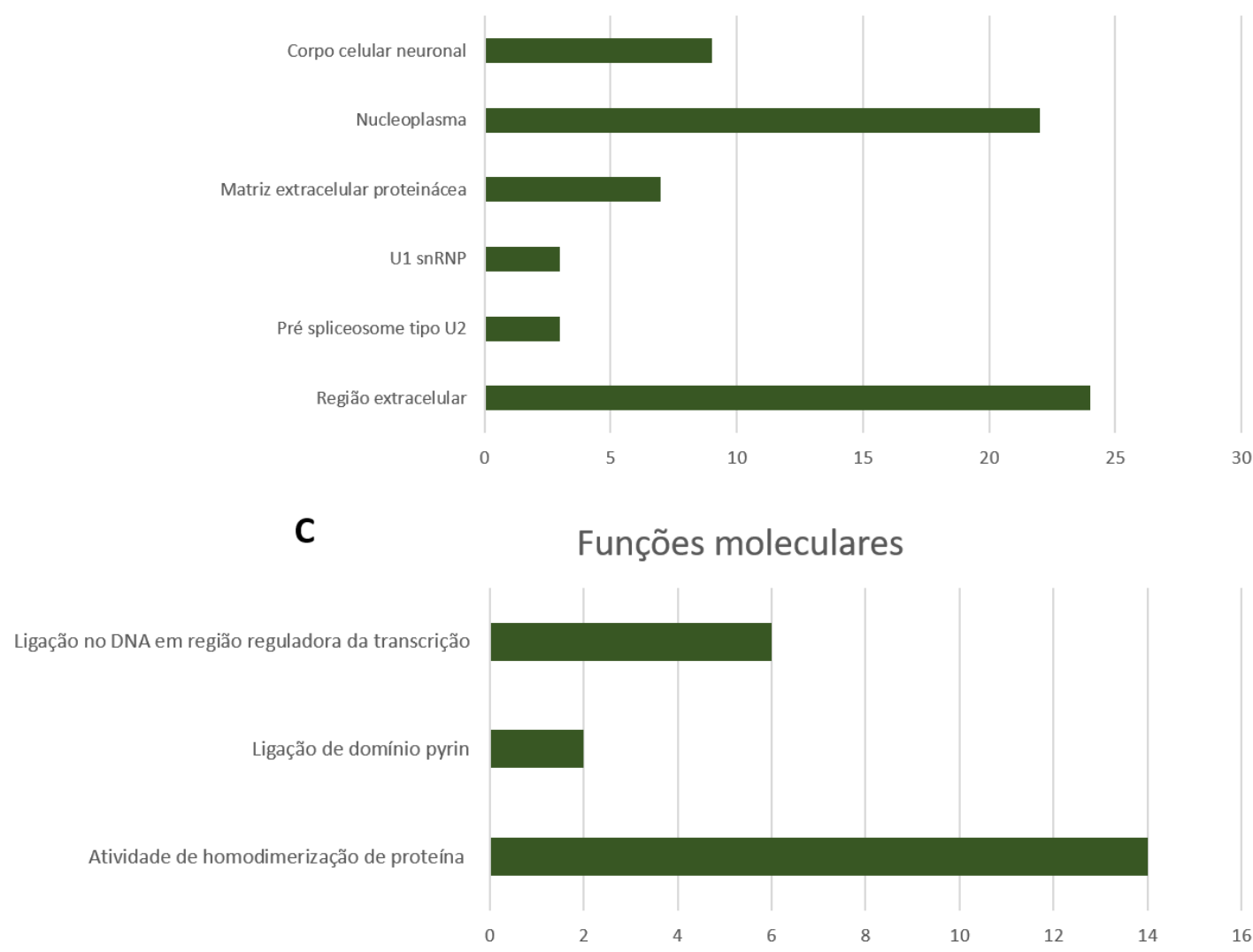

Figura 18. Enriquecimento funcional dos mRNAs sub-regulados (Plataforma DAVID Bioinformatics Resources 6.8 Database, score <0,05). (A) processos biológicos, (B) componentes celulares e (C) Funções moleculares. 


\subsection{Análise da migração de timócitos}

Para avaliar o efeito do miR-155 mimic sobre as propriedades quimiotáticas das células mTEC 3.10, foi realizado o ensaio de migração de timócitos, uma vez que cinco dos mRNAs sub-expressos estão relacionados com migração (ERBB4, EFNA1, PRKCI, PRSS37 e MATK).

Como já explicado, foram utilizados meios de cultura condicionados provenientes de culturas de células mTEC controle ou transfectadas (24 horas após a transfecção). Ainda para recordar, os timócitos em processo de migração são fixados nos insertos e corados, as imagens são analisadas pela média de pixels na área do inserto (pixels/área), em que um inserto sem nenhum timócito corado teria uma média de 0 e a partir desse ponto, quanto mais timócitos fixados e corados, maior a média, até um limite de 255 (valor mínimo e máximo dos pixels), indicando uma maior taxa migratória.

É possível observar (Figura 19) redução de aprox. 34.7\% no número de timócitos que migraram através dos insertos em contato com meio de cultura condicionado de células transfectadas em relação ao meio das células controle. 


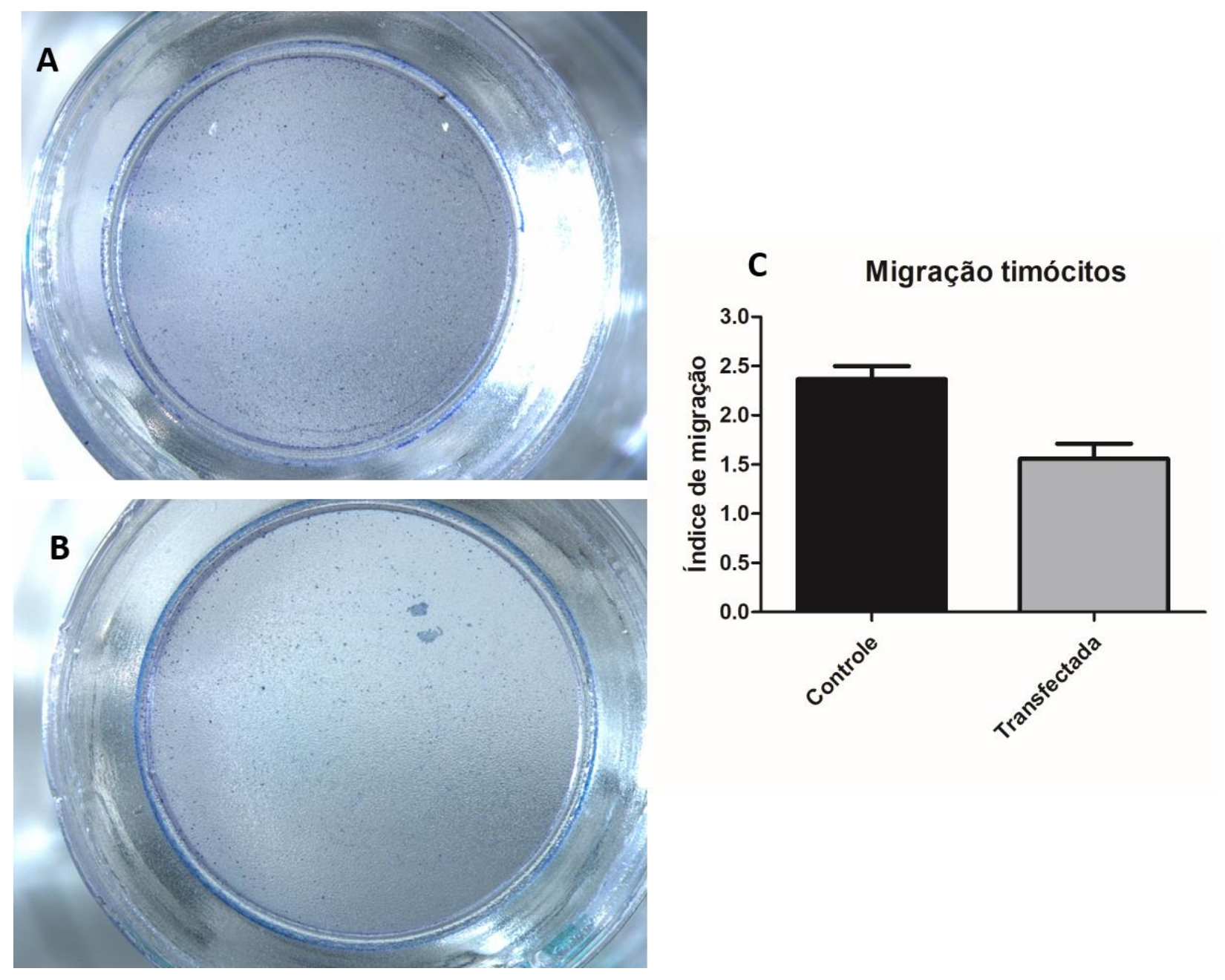

Figura 19. Migração de timócitos. (A) Migração de timócitos com meio condicionado de células mTEC 3.10 controle (B) Migração de timócitos com meio condicionado de células mTEC 3.10 transfectadas com miR-155 mimic. (C) Ográfico resultante da análise, representa a média de pixels por área. Houve uma redução de aprox. $34.2 \%$ na migração de timócitos em contato com meio condicionado de células mTEC 3.10 transfectadas com miR-155 mimic. Test $t$-student $p=$ 0.0022 . 
DISCUSSÃO 


\section{Discussão}

As células tímicas epiteliais medulares (mTECs) são as principais mediadoras do processo de seleção negativa dos timócitos autoreativos no timo (PASSOS et al., 2018). Essas células expressam grande diversidade de auto antígenos abreviadamente TRAs (do inglês tissue restricted antigens). Essa diversidade de expressão foi denominada de expressão gênica promiscua (PGE de promiscuous gene expression) e um dos grandes controladores dessa expressão é o gene Autoimmune regulator (Aire) juntamente com o gene Fez family zinc finger 2 (Fezf2) (KLEIN et al, 2014, ST-PIERRE et al., 2015, PASSOS et al 2018).

Como a PGE num timo normal abrange virtualmente todos ao TRAs, isso possibilita que a tolerância imunológica central seja voltada a todos os tecidos e órgãos do corpo. De fato, as mTECs Aire+ chegam a expressar até $62 \%$ de todos os genes codificadores de proteínas do camundongo. Além disso Aire é o maior responsável por controlar a expressão de TRAs atuando como um fator de transcrição não clássico (SANSOM et al., 2014, ST-PIERRE et al., 2015; PASSOS et al 2018) Recentemente, descobriram que o gene FEZ Family zinc finger 2 (Fezf2) também atua no controle transcricional de TRAs de maneira independente de Aire e por um mecanismo de ação similar a um fator de transcrição clássico (TAKABA et al, 2015).

Nosso grupo de pesquisa vem trabalhando nesse assunto a alguns anos e além de demonstrarmos que variações na expressão de Aire está associada a variações na expressão dos diversos TRAs (PASSOS et al., 2018, PASSOS et al., 2015), demonstramos que Aire controla a expressão de RNAs não codificantes, como miRNAs (MACEDO et al., 2013) e, mais recentemente, RNAs longos não codificantes (IncRNAs).

Agora nosso grupo está interessado numa possível interdependência entre Aire e miRNAs nas células mTEC (PASSOS et al., 2015; PASSOS et al., 2018; UCAR et al., 2013).

Uma das perguntas atuais e ainda não respondidas na imunogenética molecular é se miRNAs poderiam exercer controle pós transcricional sobre o mRNA de Aire.

Neste trabalho de mestrado adotamos essa questão e para tentar resolver isso, fizemos a predição in silico (utilizando algoritmos computacionais) daqueles miRNAs que têm o potencial de interagir (hibridar) com a região 3'UTR do mRNA de Aire. O miR-155 
é um forte candidato a exercer esse tipo de efeito por aparecer na predição computacional com forte interação do tipo miRNA-mRNA.

Logo em seguida realizamos experimentos de bancada para tentar validar a predição in silico. Fizemos transfecções de miR-155-5p mimic (um análogo ao miR-155 natural) em células mTEC 3.10 in vitro em cultura e em seguida ensaiamos a expressão transcricional de Aire por RT-qPCR.

Diferentes tempos após a transfecção do miR-155-5p mimic, assim como diferentes concentrações, foram testados e o tempo de 12 horas com $2 \mathrm{nM}$ se mostraram as melhores condições visando a maior concentração do miR-155 intracelular. No período de 24 horas após a transfecção do miR-155-5p mimic, houve redução drástica no nível de expressão transcricional de Aire, sugerindo degradação do seu mRNA pelo complexo RISC.

Os níveis do miR-155 voltaram ao normal, ou seja, comparável as culturas controle, 24 horas após a transfecção. Quanto aos níveis do mRNA de Aire observamos que 48 horas após a transfecção não havia mais diferença significativa na sua expressão comparando as culturas controles e transfectadas. Isso definiu uma "janela" para fazermos observações pós transfecção: 12 horas para o miR-155 ou 24 horas para 0 mRNA de Aire. Isso provavelmente se deve ao fato de estarmos trabalhando com um sistema análogo ao RNA de interferência (siRNA) cuja inibição do alvo é parcial e transitória (SHUKLA et al., 2011, Wahid et al., 2010). Entretanto, os níveis de "super expressão" do miR-155 e de inibição do mRNA de Aire que conseguidos nesse sistemamodelo foi suficiente para respondermos a questão principal do trabalho.

A análise por western blot e por imunofluorescência de AIRE, indicaram redução da proteína 24 horas após a transfecção do miR-155-5p mimic e na faixa de $37.3 \%$ e $15.2 \%$ respectivamente. Os níveis da proteína AIRE voltaram ao normal, comparável ao controle, 48 horas após a transfecção do miR-155-5p mimic. As análises mostraram que a dose e o tempo de ação do miR-155-5p mimic foram suficientes não apenas para afetar o mRNA de Aire, mas também sua proteína, o que sugere possíveis consequências para o transcriptoma dessas células, devido a importância de Aire na PGE em mTECs.

Além de evidenciar a redução nos níveis da proteína AIRE por western blot, a análise por imunofluorescência mostrou que esse resultado é devido a redução da 
quantidade da proteína nas células mTEC 3.10 Aire+, e não devido à redução do número de células que expressam Aire. Isso é compatível com o próprio mecanismo de ação do miR-155-5p mimic, o qual atuaria na redução do número de moléculas de mRNA de Aire.

Uma observação interessante durante a realização dos experimentos foi a redução espontânea da expressão da proteína AIRE com o tempo de cultura das células mTEC 3.10 sem que houvesse transfecção do miR-155-5p mimic. Observamos que em culturas de 48 horas já não é possível contarmos pontos fluorescentes da proteína AIRE (ensaios de imunofluorescência, Apêndice 3). Alguns estudos demonstraram a possibilidade de Aire ser um fator apoptótico para as mTECs e que as mTECs Aire ${ }^{+}$ possuem um turnover menor em comparação com as cTECs ou as mTECs Aire(ANDERSON \& SU, 2011; GRAY et al., 2006; GRAY et al., 2007; GÄBLER et al., 2007). Além disso Wang e colaboradores (2012) demonstraram que uma única mTEC expressa Aire por um curto período de tempo, podendo se limitar a no máximo 2 dias.

Experimentos suplementares precisam ser realizados para confirmar (ou não) se realmente está havendo a morte celular por apoptose nas culturas das células mTEC 3.10 Aire+.

Após evidenciar a redução da expressão do mRNA e da proteína de Aire com a transfecção do miR-155-5p mimic, passamos para a análise da expressão gênica em larga escala das células mTEC 3.10, considerando o impacto de Aire e do próprio miR155-5p no transcriptoma dessas células.

O RNA total extraído das células mTEC com 24 horas após a transfecção e das células de culturas controle foi utilizado para a análise da expressão gênica pela tecnologia dos microarrays.

Observamos que houve a modulação de 311 mRNAs, desses 103 foram superexpressos e 208 foram sub-expressos. Além disso, 249 dos 311 estão anotados nos bancos de dados de genoma. Dos mRNAs modulados e já descritos 58 (23.3\%) codificam TRAs, o que está de acordo com achados de Sansom et al (2014) em cujo trabalho observaram que cerca de $25 \%$ dos genes Aire dependentes codificam TRAs.

Dos 58 mRNAs de TRAs, 10 foram super-expressos nas células mTEC 3.10 transfectadas com miR-155-5- mimic, o que podendo esse conjunto representar uma 
parcela de genes (mRNAs) que tem sua transcrição reduzida por Aire (ST-PIERRE et al., 2015, SANSOM et al., 2014).

Considerando que os microRNA, por serem pequenos RNAs de fita simples, podem possuir diversos alvos, avaliamos quais dos mRNAs diferencialmente expressos são preditos pelo algoritmo do MirWalk como possíveis alvos do miR-155. Foram encontrados 15 mRNAs dos quais três são preditos mas sem anotações e outros 12 são preditos e com anotação: Ampd3, Bach1, Cycs, Dbn1, Gbe1, Hapln3, Kpna4, Mccc2, Ndn, Prkci, Rreb1 e Snrpn. Desses, três (Bach1, Cycs e Gbe1) foram super-expressos enquanto os outros foram sub-expressos, o que pode indicar uma ação direta do miR155 sobre a 3' UTR desses nove mRNAs.

Os resultados mostraram que a redução na expressão de Aire causada pela transfecção com o miR-155-5p mimic em células mTEC 3.10 foi o suficiente para causar a modulação de mRNAs de TRAs, que são essenciais para a representação do próprio e no processo de seleção negativa de timócitos auto reativos no timo (PASSOS et al., 2018, ANDERSON et al., 2007).

Além da expressão de mRNAs de TRAs, muitos estudos evidenciaram que a importância de Aire nas mTECs vai além do controle de TRAs na PGE (ST-PIERRE et al., 2015, SANSOM et al., 2014, PASSOS et al., 2018, ANDERSON \& SU, 2016, ABRAMSON et al., 2010, PEZZI et al., 2016). A análise de enriquecimento funcional, dos genes diferencialmente expressos, pela plataforma DAVID, nos permitiu identificar genes relacionados a essas outras funções.

Pezzi et al (2016), mostrou que Aire controla a expressão de mRNAs codificadores de proteínas ligadas a adesão celular (interação mTEC-timócito) cujo processo é essencial para a seleção negativa. Dos mRNAs sub-regulados, nós identificamos Cldn6 e Hapln3, ambos relacionados com o processo de adesão celular.

Também foram identificados aqueles mRNAs que codificam proteínas que participam da montagem do espliceossomo, como o SNRPN, PEPF39, SF3A2 e SNRPA. Diferentes trabalhos sugerem que AIRE pode também participar no processamento de mRNAs, e assim contribuir com a diversidade de isoformas dos TRAs, tanto os Aire dependentes quanto os independentes (ABRAMSON et al., 2010; KEANE et al., 2015). St-Pierre e colaboradores (2015), demonstraram que a deleção de Aire em cTECs e 
mTECs ${ }^{10}$, ou seja, aquelas que não expressam Aire, não alteram a complexidade do splicing nessas células.

Outra possível atuação de Aire é na indução do processo apoptótico nas mTECs. Apesar de essa função ainda não ser completamente confirmada, a indução da apoptose por Aire explicaria o rápido turnover das mTECs Aire ${ }^{+}$e sugere que após o processo apoptótico essas células seriam fagocitadas e seus TRAs seriam apresentados através de células apresentadoras de antígenos presentes na medula do timo, como macrófagos e células dentríticas, que auxiliam no processo de seleção negativa (PASSOS et al., 2018; ANDERSON \& SU, 2011; GRAY et al., 2007; GÄBLER et al., 2007).

Também foi possível identificar diversos genes sub-regulados que atuam na regulação positiva do processo apoptótico: ERBB4, DDX19A, MUC20, PYCARD, RHOB, PAWR, TRP73, CDK4, SIRT1, LATS1.

Dentre os mRNAs sub-regulados, foram identificados seis que estão relacionados à ativação de MAPK (Mitogen-activated protein kinase), como o ERBB4, RREB1, DMTF1, TRP73, TBL1X e BRCA1. MAPKs regulam uma diversidade de processos biológicos, como diferenciação celular e apoptose.

Os mRNAs que codificam ADAMTSL5 e ARSI também estão sub-regulados, e participam nos processos de metabolismo de proteínas e degradação de macromoléculas, respectivamente. Considerando a alta quantidade e variedade de proteínas expressas pelas mTECs, são, provavelmente, processos com uma alta demanda nessas células, muito em conta do Aire que promove grande parte dessa expressão.

Houve também a sub-regulação de genes relacionados ao processo de migração celular, dentre eles o ERBB4, EFNA1, PRKCI, PRSS37 e MATK. Laan et al (2009), mostraram que Aire aumenta a expressão de ligantes de quimiocinas importante para a migração de timócitos, como CCR7 e CCR4, sugerindo fortemente a atuação de Aire também nas propriedades quimiotáticas das mTECs e possivelmente influindo, mesmo que indiretamente, na migração dos timócitos para o timo e dentro do timo (MENDESDA-CRUZ et al., 2019).

Isso nos sugeriu analisar o efeito biológico (funcional) causado pela transfecção com o miR-155-5p mimic. O racional foi que se a transfecção desse miRNA provoca 
redução na expressão de mRNAs que codificam proteínas de migração, as células mTEC assim tratadas teriam suas propriedades quimiotáticas alteradas.

Para testar isso realizamos o ensaio de migração de timócitos. O ensaio foi realizado com o uso de insertos das placas de cultura transwell que permitem a passagem de timócitos em direção à meios de cultura condicionados (meios provenientes de culturas de mTECs controle ou de mTECs transfectadas). O processo de migração transwell foi interrompido após 3 horas, de maneira que foi possível fixar e corar, nos insertos, os timócitos em processo migratório e assim avaliar a taxa de migração (controle vs transfectados).

Os resultados mostraram redução de $37.4 \%$ na migração de timócitos em meio proveniente das células transfectadas com miR-155-5p. Isso confirma, ao nível biológico, que a modulação de Aire e consequentemente de mRNAs que codificam proteínas quimiotáticas pode ter consequências funcionais.

Este trabalho teve como objetivo identificar pelo menos um microRNA que pudesse controla o mRNA DE Aire. A transfecção do miR-155 mimic (2 nM) em células mTEC 3.10 foi o suficiente para reduzir a expressão mRNA de Aire por um período de até 24 horas. Apesar do efeito da transfecção ser transitório, foi o bastante para reduzir os níveis da proteína Aire. Houve também a modulação de centenas de mRNAs nessas células, e apesar de ser preciso considerar o efeito que o miR-155 possa ter sobre eles, apenas 15 dos 311 genes modulados são alvos preditos do miR-155.

Além disso, quase um quarto dos mRNAs sub-regulados codificam TRAs e eles puderam ser agrupados em diferentes processos biológicos nos quais há envolvimento de Aire nas mTECs, como apoptose, splicing alternativo, adesão e migração, indicando que a modulação desses genes pode ter sido causado pela redução de AIRE nas células mTEC 3.10.

Finalmente, nossos resultados evidenciaram que Aire pode ser regulado a nível pós transcricional por miR-155. 
CONCLUSÃO 


\section{Conclusões}

- O mRNA de Aire pode ser regulado por miR-155.

- Além disso, o miR-155 tem efeito amplo nas células mTEC regulando um conjunto diverso de mRNAs.

- Isso tem consequências biológicas importantes como por exemplo influi nas propriedades quimiotáticas das células mTEC sobre timócitos 
REFERÊNCIAS BIBLIOGRÁFICAS 


\section{Referências bibliográficas}

AALTONEN, J.; BJÖRSES, P.; PERHEENTUPA, J.; et al. An autoimmune disease, APECED, caused by mutations in a novel gene featuring two PHD-type zinc-finger domains. Nature Genetics, v. 17, n. 4, p. 399-403, 1997.

ABRAMSON, J.; GIRAUD, M.; BENOIST, C.; et al. Aire's Partners in the Molecular Control of Immunological Tolerance. Cell, v. 140, n. 1, p. 123-135, 2010. Disponível em: <http://dx.doi.org/10.1016/j.cell.2009.12.030>.

ANDERSON, G.; LANE, P. J. L.; JENKINSON, E. J. Generating intrathymic microenvironments to establish T-cell tolerance. Nature Reviews Immunology, v. 7, n. 12, p. 954-963, 2007.

ANDERSON, M. S.; SU, M. A. AIRE expands: New roles in immune tolerance and beyond. Nature Reviews Immunology, $\begin{array}{lllll}\text { v. } 16, & \text { n. } 4, & \text { p. 247-258, } 2016 . & \text { Disponível em: }\end{array}$ $<$ http://dx.doi.org/10.1038/nri.2016.9>.

ANDERSON, M. S.; VENANZI, E. S.; KLEIN, Ludger; et al. Projection of an immunological selfshadow within the thymus by the aire protein. Science, v. 298, n. 5597, p. 1395-1401, 2002.

ANDERSON, M. S; SU, M. A. Aire and T cell Development. v. 23, n. 2, p. 1-13, 2011.

BENJAMINI, Y.; HOCHBERG, Y. Controlling the false discovery rate: a practical and powerful approach to multiple testing. Journal of the Royal Statistical Society. Series B (Methodological), p. 289-300, 1995.

BLIZZARD, By R M; KYLE, M. Studies of the Adrenal Antigens and Antibodies in Addison's Disease. Journal of Clinical Investigation, v. 42, n. 10, p. 1653-1660, 1963.

BRUSERUD, Ø.; OFTEDAL, B. E.; WOLFF, A. B.; et al. AlRE-mutations and autoimmune disease. Current Opinion in Immunology, v. 43, p. 8-15, 2016. Disponível em: $<$ http://dx.doi.org/10.1016/j.coi.2016.07.003>. 
BUROCCHI, A.; PITTONI, P.; TILI, E.; et al. Regulated expression of miR-155 is required for iNKT cell development. Frontiers in Immunology, v. 6, n. MAR, p. 1-8, 2015.

CHIANG, H. R.; SCHOENFELD, L. W.; RUBY, J. G.; et al. Mammalian microRNAs: Experimental evaluation of novel and previously annotated genes. Genes and Development, v. 24, n. 10, p. 992-1009, 2010.

DUDDA, J. C; SALAUN, B.; JI, Y.; et al. MicroRNA-155 is required for effector CD8+ T cell responses to virus infection and cancer. Immunity, v. 38, n. 4, p. 742-753, 2013.

GÄBLER, J.; ARNOLD, J.; KYEWSKI, B.. Promiscuous gene expression and the developmental dynamics of medullary thymic epithelial cells. European Journal of Immunology, v. 37, n. 12, p. 3363-3372, 2007.

GEBERT, L. F.R.; MACRAE, I. J. Regulation of microRNA function in animals. Nature Reviews Molecular Cell Biology, $\quad$ v. 20, $\quad$ n. 1, $\quad$ p. 21-37, $2018 . \quad$ Disponível em: $<$ http://dx.doi.org/10.1038/s41580-018-0045-7>.

GEENEN, V \& SAVINO, W. History of the Thymus: From a Vestigial Organ to the Programming of Immunological Self-Tolerance . In: PASSOS, G. A. (Ed.). Thymus Transcriptome and Cell Biology. Suiça: Springer Nature, 2019. Cap. 1, p. 1-18.

GIRAUD, M. \& PETERSON, P. The Autoimmune Regulator (AIRE) Gene, the Master Activator of Self-Antigen Expression in the Thymus.In: PASSOS, G. A. (Ed.). Thymus Transcriptome and Cell Biology. Suiça: Springer Nature, 2019. Cap. 7, p. 169-190.

GIRAUD, M.; YOSHIDA, H.; ABRAMSON, J.; RAHL P. B.; YOUNG, R. A.; MATHIS, D.; BENOIST, C. Aire unleashes stalled RNA polymerase to induce ectopic gene expression in thymic epithelial cells. Proceedings of the National Academy of Sciences of the United States of America. v.109, p.535-540, 2012.

GRAY, D. H. D.; LEW, A. M.; SEACH, N.; et al. Developmental kinetics, turnover, and stimulatory capacity of thymic epithelial cells. Blood, v. 108, n. 12, p. 3777-3785, 2006. 
GRAY, D.; ABRAMSON, J.; BENOIST, C.; et al. Proliferative arrest and rapid turnover of thymic epithelial cells expressing Aire. The Journal of Experimental Medicine, v. 204, n. 11, p. $2521-$ 2528, 2007.

HUSEbye, E. S.; PERHEentuPA, J.; RAUTEMAA, R.; et al. Clinical manifestations and management of patients with autoimmune polyendocrine syndrome type i. Journal of Internal Medicine, v. 265, n. 5, p. 514-529, 2009.

IRLA, M. Thymic Crosstalk: An Overview of the Complex Cellular Interactions That Control the Establishment of T-Cell Tolerance. In: PASSOS, G. A. (Ed.). Thymus Transcriptome and Cell Biology. Suiça: Springer Nature, 2019. Cap. 6, p. 149-168.

KEANE, P.; CEREDIG, R.; SEOIGHE, Cathal. Promiscuous mRNA splicing under the control of AIRE in medullary thymic epithelial cells. Bioinformatics, v. 31, n. 7, p. 986-990, 2015.

KHAN, Imran S; TANIGUCHI, Ruth T; FASANO, K. J; et al. Canonical microRNAs in thymic epithelial cells promote central tolerance. European Journal of Immunology, v. 44, n. 5, p. 1313-1319, 2014.

KLEIN, L.; KYEWSKI, B.; ALLEN, P. M; et al. Positive and negative selection of the T cell repertorie: what thymocytes see and don't see. Nature Reviews Immunology, v. 14, n. 6, p. 377-391, 2016.

KOHLHAAS, S.; GARDEN, O. A.; OKKENHAUG, K.; et al. Cutting Edge: The Foxp3 Target miR155 Contributes to the Development of Regulatory T Cells. The Journal of Immunology, v. 182, n. 5, p. 2578-2582, 2009.

KROL, J.; LOEDIGE, I.; FILIPOWICZ, W. The widespread regulation of microRNA biogenesis, function and decay. Nature Reviews Genetics, v. 11, n. 9, p. 597-610, 2010. Disponível em: $<$ http://dx.doi.org/10.1038/nrg2843>.

KYEWSKI, B.; DERBINSKI, J. Self-representation in the thymus: An extended view. Nature Reviews Immunology, v. 4, n. 9, p. 688-698, 2004. 
LAAN, M.; KISAND, K.; KONT, V.; et al. Aire deficiency results in decreased expression of CCR4 and CCR7 ligands and in delayed migration of CD4+ thymocytes1 Europe PMC Funders Group. J Immunol, v. 183, n. 12, p. 7682-7691, 2009.

LAEMMLI, U. K., FAVRE, M. Maturation of the head of bacteriophage T4.I. DNA packaging events. J. Mol. Biol. v.15:80(4), p.575-599, 1973.

LEE, R. C.; FEINBAUM, R. L.; AMBROS, V. The C. elegans heterochronic gene lin-4 encodes small RNAs with antisense complementarity to lin-14. Cell. v.75, n.5, p.843-854, 1993.

LIVAK, K. J.; SCMITTGEN, T. D. Analysis of relative gene expression data using real-time quantitative PCR and the 2(-Delta Delta C(T). Method.v. 25, p.402-408, 2001.

MACEDO, C.; EVANGELISTA, A. F.; MARQUES, M. M.; et al. Autoimmune regulator (Aire) controls the expression of microRNAs in medullary thymic epithelial cells. Immunobiology, v. 218, n. 4, p. 554-560, 2013. Disponível em: <http://dx.doi.org/10.1016/j.imbio.2012.06.013>.

MASHIMA, R. Physiological roles of miR-155. Immunology, v. 145, n. 3, p. 323-333, 2015. MATHIS, D.; BENOIST, C. A decade of AIRE. Nature Reviews Immunology, v. 7, n. August, p. 645-650, 2007.2 Disponível em: <http://www.nature.com.iclibezp1.cc.ic.ac.uk/articles/nri2136.pdf>.

MATSUO, T.; TOMINAGA, R.; YOSHIMURA, A.; et al. Regulation of human autoimmune regulator (AIRE) gene translation by miR-220b. Gene, v. 530, n. 1, p. 19-25, 2013. Disponível em: <http://dx.doi.org/10.1016/j.gene.2013.08.015>.

MENDES-DA-CRUZ, D. A. et al. Intrathymic Cell Migration: Implications in Thymocyte Development and T-Cell Repertoire Formation. In: PASSOS, G. A. (Ed.). Thymus Transcriptome and Cell Biology. Suiça: Springer Nature, 2019. Cap. 5, p. 117-148.

MUNOZ, J. J. \& ZAPATA, A. G. Thymus Ontogeny and Development . In: PASSOS, G. A. (Ed.). Thymus Transcriptome and Cell Biology. Suiça: Springer Nature, 2019. Cap. 2, p. 19-34. 
NAGAMINE, K.; PETERSON, P.; SCOTT, H. S.; et al. Positional cloning of the APECED gene. Nature Genetics, v. 17, n. 4, p. 393-398, 1997.

NOSSAL, G. J. V. Cellular Mechanisms of Immunologic Tolerance. Annual Review of Immunology, v. 1, n. 1, p. 33-62, 2003.

OLENA, A. F.; PATTON, J. G. Genomic organisation of miRNAs. Journal of Cellular Physiology, v. 222, n. 3, p. 540-545, 2014.

PASSOS, G. A. et al. The Thymus as a Mirror of the Body's Gene Expression. In: PASSOS, G. A. (Ed.). Thymus Transcriptome and Cell Biology. Suiça: Springer Nature, 2019. Cap. 9, p. 215-234.

PASSOS, G. A.; MENDES-DA-CRUZ, D. A.; OLIVEIRA, E. H. The thymic orchestration involving Aire, miRNAs and cell-cell interactions during the induction of central tolerance. Frontiers in Immunology, v. 6, n. JUN, p. 1-7, 2015.

PASSOS, G. A.; MENDES-DA-CRUZ, D. A.; OLIVEIRA, E. H.. The Role of Aire, microRNAs and Cell-Cell Interactions on Thymic Architecture and Induction of Tolerance. [s.l.]: Frontiers in Immunology, 2015.2 Disponível em: <http://www.frontiersin.org/books/The_Role_of_Aire_microRNAs_and_Cell Cell_Interactions_on_Thymic_Architecture_and_Induction_of_Toler/795>.

PASSOS, G. A.; SPECK-HERNANDEZ, C. A.; ASSIS, A. F.; et al. Update on Aire and thymic negative selection. Immunology, v. 153, n. 1, p. 10-20, 2018.

PETERSON, P.; PITKÄNEN, J.; SILLANPÄÄ, N.; et al. Autoimmune polyendocrinopathy candidiasis ectodermal dystrophy (APECED): A model disease to study molecular aspects of endocrine autoimmunity. Clinical and Experimental Immunology, v. 135, n. 3, p. 348-357, 2004.

PEZZI, N.; ASSIS, A. F.; COTRIM-SOUSA, L. C.; et al. Aire knockdown in medullary thymic epithelial cells affects Aire protein, deregulates cell adhesion genes and decreases thymocyte 
interaction. Molecular Immunology, v. 77, p.157-173, 2016. Disponível em: <http://dx.doi.org/10.1016/j.molimm.2016.08.003>.

REINHART BJ, SLACK FJ, BASSON $M$, et al. The 21-nucleotide let-7 RNA regulates developmental timing in Caenorhabditis elegans. Nature. 2000; 403:901-906.

RODRIGUEZ, A.; VIGORITO, E.; CLARE, S.; et al. UKPMC Funders Group Requirement of bic / microRNA-155 for Normal Immune Function. Science, v. 316, n. 5824, p. 608-611, 2008.

RUEHL-FEHLERT, C., KITTEL, B., MORAWIETZ, G., DESLEX, P., KEENAN, C., MAHRT, C. R; et al. NACAD Group. (2003). Revised guides for organ sampling and trimming in rats and mice-part 1. Experimental and Toxicologic Pathology : Official Journal of the Gesellschaft Fur Toxikologische Pathologie, 55(2-3), 91-106.

SAFIEDDINE, N., \& KESHAVJEE, S. (2011). Anatomy of the Thymus Gland. Thoracic Surgery Clinics, 21(2), 191-195.

SANSOM, S. N.; PONTING, C. P.; NUSSPAUMER, G.; et al. Population and single-cell genomics reveal the Aire dependency, relief from Polycomb silencing, and distribution of self-antigen expression in thymic epithelia. Genome Research, v. 24, n. 12, p. 1918-1931, 2014.

SHUKLA, G. C.; SINGH, J.; BARIK, S. MicroRNAs: Processing, Maturation, Target Recognition and Regulatory Functions. Molecular and cellular pharmacology, v. 3, n. 3, p. 83-92, 2011. Disponível em: <http://www.ncbi.nlm.nih.gov/pubmed/22468167\%0Ahttp://www.pubmedcentral.nih.gov/articlere nder.fcgi?artid=PMC3315687>.

SLACK FJ, BASSON M, LIU ZC, et al. The lin-41 RBCC gene acts in the C-elegans heterochronic pathway between the let-7 regulatory RNA and the LIN-29 transcription factor. Mol Cell. 2000; 5:659-669.

ST-PIERRE, C.; BROCHU, S.; PERREAULT, C.; et al. Differential Features of AIRE-Induced and AIRE-Independent Promiscuous Gene Expression in Thymic Epithelial Cells. The Journal of Immunology, v. 195, n. 2, p. 498-506, 2015. 
SU, L. C.; HUANG, A. F.; JIA, H.; et al. Role of microRNA-155 in rheumatoid arthritis. International Journal of Rheumatic Diseases, v. 20, n. 11, p. 1631-1637, 2017.

TAKABA, H.; NITTA, T.; TAKAYANAGI, H.; et al. Fezf2 Orchestrates a Thymic Program of SelfAntigen Expression for Immune Tolerance. Cell, v. 163, n. 4, p. 975-987, 2015. Disponível em: <http://dx.doi.org/10.1016/j.cell.2015.10.013>.

UCAR, O.; TYKOCINSKI, L. O.; DOOLEY, J.; et al. An evolutionarily conserved mutual interdependence between Aire and microRNAs in promiscuous gene expression. European Journal of Immunology, v. 43, n. 7, p. 1769-1778, 2013.

VASCONCELOS-FONTES, L. et al. Development of Thymic Regulatory T Lymphocytes. In: PASSOS, G. A. (Ed.). Thymus Transcriptome and Cell Biology. Suiça: Springer Nature, 2019. Cap. 12, p. 255-272.

VIGORITO, E.; PERKS, K. L.; ABREU-GOODGER, C.; et al. microRNA-155 Regulates the Generation of Immunoglobulin Class-Switched Plasma Cells. Immunity, v. 27, n. 6, p. 847-859, 2007.

WAHID, F.; SHEHZAD, A.; KHAN, T.; et al. MicroRNAs: Synthesis, mechanism, function, and recent clinical trials. Biochimica et Biophysica Acta - Molecular Cell Research, v. 1803, n. 11, p. 1231-1243, 2010. Disponível em: <http://dx.doi.org/10.1016/j.bbamcr.2010.06.013>.

WANG, X.; BICHELE, R.; PETERSON, P.; et al. Post-Aire Maturation of Thymic Medullary Epithelial Cells Involves Selective Expression of Keratinocyte-Specific Autoantigens. Frontiers in Immunology, v. 3, n. 19, p. 1-16, 2012.

WIGHTMAN B, HA I, RUVKUN G. Posttranscriptional regulation of the heterochronic gene lin-14 by lin-4 mediates temporal pattern formation in C. elegans. Cell. 1993; 75:855-862.

WINTER, J.; JUNG, S.; KELLER, S.; et al. Many roads to maturity: microRNA biogenesis pathways and their regulation. Nature Cell Biology, v. 11, n. 3, p. 228-234, 2009. 
XU, M.; GAN, T.; NING, H.; et al. MicroRNA functions in thymic biology: Thymic development and involution. Frontiers in Immunology, v. 9, n. SEP, p. 1-8, 2018.

YOGANATHAN, K. et al. T-Cell Development: From T-Lineage Specification to Intrathymic Maturation. In: PASSOS, G. A. (Ed.). Thymus Transcriptome and Cell Biology. Suiça: Springer Nature, 2019. Cap. 4, p. 67-116. 
APÊNDICE 
10. Apêndice

Apêndice 1 - Lista dos genes diferencialmente expressos ( $F C \geq 1.5)$

\begin{tabular}{|c|c|c|c|}
\hline \multicolumn{4}{|c|}{ Genes super-expressos } \\
\hline Nome & $\mathrm{FC}$ & Nome & FC \\
\hline Lars2 & 12.347 & Sorl1 & 1.706 \\
\hline J00623 & 5.109 & LOC552912 & 1.701 \\
\hline Fam13c & 4.487 & App & 1.686 \\
\hline BC052554 & 4.456 & BE953138 & 1.675 \\
\hline BP760463 & 4.165 & AK042659 & 1.671 \\
\hline Lalba & 3.441 & AK088546 & 1.670 \\
\hline Macf1 & 3.191 & Capn3 & 1.668 \\
\hline Rmrp & 3.036 & Snora69 & 1.663 \\
\hline Paqr3 & 3.027 & A_51_P301713 & 1.648 \\
\hline Tsix & 2.913 & Zfp862-ps & 1.646 \\
\hline NAP052266-1 & 2.910 & Arsa & 1.646 \\
\hline NAP030020-1 & 2.745 & Rnu33 & 1.645 \\
\hline A_52_P972871 & 2.669 & Pbp2 & 1.630 \\
\hline BC026852 & 2.584 & Nxnl2 & 1.629 \\
\hline Mdfi & 2.532 & TC1640144 & 1.618 \\
\hline A_52_P477386 & 2.406 & Fam58b & 1.604 \\
\hline Drd3 & 2.364 & Ube2g2 & 1.601 \\
\hline A_52_P917036 & 2.329 & Diap3 & 1.599 \\
\hline Gm20721 & 2.155 & Efha1 & 1.598 \\
\hline Expi & 2.094 & Phyhd1 & 1.594 \\
\hline TC1677245 & 2.070 & Oas1f & 1.592 \\
\hline NAP092627-001 & 2.066 & Mterfd3 & 1.592 \\
\hline TC1622094 & 2.065 & Ndrg1 & 1.587 \\
\hline Bach1 & 2.032 & NAP123925-1 & 1.587 \\
\hline P4ha2 & 2.028 & Fbrsl1 & 1.585 \\
\hline NAP108369-1 & 2.027 & Gm43668 & 1.578 \\
\hline AK082597 & 1.998 & 4930481A15Rik & 1.570 \\
\hline Hist2h2aa1 & 1.964 & Ccdc28a & 1.570 \\
\hline D10Bwg1070e & 1.945 & Dock5 & 1.567 \\
\hline AK012844 & 1.899 & Gbe1 & 1.562 \\
\hline Lip1 & 1.897 & Mif4gd & 1.560 \\
\hline 1700025G04Rik & 1.895 & Ap1b1 & 1.556 \\
\hline AK014007 & 1.874 & Hnrph3 & 1.546 \\
\hline Stat2 & 1.848 & Rif1 & 1.544 \\
\hline Mmgt2 & 1.846 & Zfp46 & 1.544 \\
\hline Fbxl18 & 1.829 & 2410022M11Rik & 1.544 \\
\hline
\end{tabular}




\begin{tabular}{|c|c|c|c|}
\hline 4933406C10Rik & 1.820 & Elovl7 & 1.541 \\
\hline Cep19 & 1.781 & Tep1 & 1.537 \\
\hline TC1707241 & 1.777 & Snx1 & 1.535 \\
\hline Duoxa1 & 1.763 & Nipa1 & 1.534 \\
\hline Ndufa8 & 1.759 & ENSMUST00000059184 & 1.528 \\
\hline 1810026B05Rik & 1.740 & Cycs & 1.526 \\
\hline Kcnh2 & 1.738 & 2010107E04Rik & 1.525 \\
\hline 3222402P14Rik & 1.738 & AK081941 & 1.523 \\
\hline Heatr5b & 1.734 & $\mathrm{BC} 003331$ & 1.523 \\
\hline$Z x d b$ & 1.728 & Pkig & 1.520 \\
\hline TC1668068 & 1.725 & Gtf2h1 & 1.519 \\
\hline NAP125102-1 & 1.716 & Adck5 & 1.517 \\
\hline TC1704781 & 1.714 & Gbas & 1.514 \\
\hline Kcna7 & 1.713 & Fdxacb1 & 1.511 \\
\hline Pomgnt2 & 1.711 & St3gal1 & 1.509 \\
\hline Lrrk1 & 1.709 & & \\
\hline \multicolumn{4}{|c|}{ Genes sub-expressos } \\
\hline Nome & $\mathrm{FC}$ & Nome & $\mathrm{FC}$ \\
\hline Gm5513 & -1.506 & Sfrs4 & -1.730 \\
\hline Ltbp1 & -1.508 & Schip1 & -1.730 \\
\hline Hcfc1r1 & -1.510 & Inhba & -1.734 \\
\hline Rbm35a & -1.511 & Efna1 & -1.736 \\
\hline Upf1 & -1.515 & Lhb & -1.736 \\
\hline BC039142 & -1.516 & BG294955 & -1.737 \\
\hline Prpf39 & -1.521 & Arsi & -1.741 \\
\hline R3hdm4 & -1.526 & A_52_P453315 & -1.743 \\
\hline Cylc2 & -1.526 & C1qb & -1.744 \\
\hline Pcgf1 & -1.526 & Shoc2 & -1.745 \\
\hline Cilp2 & -1.529 & Hrh3 & -1.752 \\
\hline Rab12 & -1.530 & Statip1 & -1.755 \\
\hline Dbn1 & -1.530 & Odf3 & -1.756 \\
\hline Wsb1 & -1.533 & Syt16 & -1.758 \\
\hline Drd1ip & -1.537 & Fbxo34 & -1.758 \\
\hline Mobp & -1.539 & Olfr544 & -1.759 \\
\hline Ube2s & -1.540 & Hoxc4 & -1.766 \\
\hline Phc2 & -1.544 & Rhob & -1.781 \\
\hline Sox15 & -1.544 & A_51_P421578 & -1.786 \\
\hline Cdk4 & -1.545 & LOC670046 & -1.798 \\
\hline Lass2 & -1.546 & Ccdc50 & -1.804 \\
\hline Rasa1 & -1.549 & Ampd3 & -1.809 \\
\hline Gm8358 & -1.549 & Lrrc8c & -1.809 \\
\hline
\end{tabular}




\begin{tabular}{|c|c|c|c|}
\hline Taf6l & -1.552 & 1810010M01Rik & -1.815 \\
\hline Cspg5 & -1.553 & Crhr1 & -1.815 \\
\hline Ppp1r8 & -1.553 & Dmtf1 & -1.817 \\
\hline Slc1a5 & -1.553 & Gm27640 & -1.818 \\
\hline Cib2 & -1.555 & S100a11 & -1.820 \\
\hline Zp1 & -1.561 & Cdc42se1 & -1.831 \\
\hline Efr3a & -1.565 & Gm4252 & -1.845 \\
\hline Tcfсp2 & -1.565 & Adamtsl5 & -1.846 \\
\hline Pgrmc1 & -1.567 & Myl3 & -1.847 \\
\hline Trappc1 & -1.568 & KIf10 & -1.852 \\
\hline Tas2r140 & -1.568 & Xpo4 & -1.856 \\
\hline Tacstd1 & -1.570 & Prkci & -1.859 \\
\hline Sult1c2 & -1.570 & $\mathrm{Ndn}$ & -1.881 \\
\hline Mpp2 & -1.577 & 2010109A12Rik & -1.882 \\
\hline Kpna4 & -1.579 & Snrpn & -1.883 \\
\hline A_51_P222946 & -1.581 & Casd1 & -1.891 \\
\hline Cbln1 & -1.581 & Hapln3 & -1.892 \\
\hline Man2b2 & -1.583 & Gp1bb & -1.899 \\
\hline Btbd5 & -1.586 & Vrk1 & -1.899 \\
\hline Sdk2 & -1.588 & NAP049888-1 & -1.902 \\
\hline Pycard & -1.590 & Usp43 & -1.914 \\
\hline Sf3a2 & -1.591 & Dock6 & -1.915 \\
\hline Bmp5 & -1.592 & Rsc1a1 & -1.915 \\
\hline Gm12946 & -1.592 & Cct6a & -1.932 \\
\hline Tmem81 & -1.596 & Erbb4 & -1.935 \\
\hline Rreb1 & -1.599 & TC1599525 & -1.937 \\
\hline Vangl1 & -1.601 & Dhrs11 & -1.942 \\
\hline Elovl5 & -1.601 & Gm4989 & -1.950 \\
\hline Cpsf7 & -1.606 & Olfr744 & -1.959 \\
\hline Fbxi6 & -1.609 & Atpbd3 & -1.963 \\
\hline Lrrc46 & -1.612 & Tmeff1 & -1.981 \\
\hline Slc25a16 & -1.612 & Crebl1 & -1.999 \\
\hline ENSMUST00000058057 & -1.613 & Lrrc49 & -2.004 \\
\hline Jund1 & -1.613 & Ipcef1 & -2.016 \\
\hline Msrb3 & -1.615 & A_52_P1197192 & -2.029 \\
\hline Brca1 & -1.617 & Zfhx2as & -2.030 \\
\hline Tcl1b3 & -1.618 & E130304I02Rik & -2.033 \\
\hline V1rc8 & -1.618 & Fam122b & -2.061 \\
\hline Sirt1 & -1.620 & Faim2 & -2.073 \\
\hline Plod2 & -1.622 & Cdh3 & -2.077 \\
\hline Fmod & -1.623 & Slc29a1 & -2.087 \\
\hline
\end{tabular}




\begin{tabular}{|c|c|c|c|}
\hline Pde4c & -1.628 & Mccc2 & -2.098 \\
\hline Srgap3 & -1.630 & 4921507G05Rik & -2.099 \\
\hline NAP055071-1 & -1.633 & Ly6g5b & -2.102 \\
\hline Muc20 & -1.634 & Mid1 & -2.111 \\
\hline Bcar3 & -1.635 & Xcr1 & -2.121 \\
\hline Rc3h1 & -1.637 & Pawr & -2.131 \\
\hline Bzw1 & -1.638 & Qrfp & -2.134 \\
\hline Fam122a & -1.640 & Dusp23 & -2.135 \\
\hline Ptcra & -1.645 & Prss37 & -2.142 \\
\hline Lats1 & -1.646 & Col4a3 & -2.157 \\
\hline Stard3nl & -1.648 & Defcr3 & -2.162 \\
\hline Kdelr1 & -1.649 & Ryk & -2.166 \\
\hline Trp73 & -1.651 & 1700120K04Rik & -2.168 \\
\hline Mpped1 & -1.652 & Ddx19a & -2.177 \\
\hline Rrad & -1.653 & Bpil3 & -2.191 \\
\hline Grit & -1.658 & Clps & -2.193 \\
\hline Snrpa & -1.666 & Usp21 & -2.199 \\
\hline Zbtb7c & -1.668 & Shc2 & -2.218 \\
\hline Asgr1 & -1.668 & A_51_P414188 & -2.224 \\
\hline Bpifa5 & -1.669 & Spnb4 & -2.255 \\
\hline Banf1 & -1.671 & NAP123939-1 & -2.256 \\
\hline 2310079G19Rik & -1.673 & Tmc1 & -2.256 \\
\hline Csf2rb1 & -1.678 & Pnmt & -2.256 \\
\hline D930028M14Rik & -1.679 & Defb15 & -2.303 \\
\hline Olfr611 & -1.684 & Cldn6 & -2.317 \\
\hline Sart2 & -1.685 & Kif20b & -2.318 \\
\hline Gm13012 & -1.685 & Alpi & -2.367 \\
\hline Zfp574 & -1.686 & Nlrp2 & -2.374 \\
\hline Utx & -1.691 & AK039782 & -2.376 \\
\hline Tcfap2a & -1.691 & E130119H09Rik & -2.400 \\
\hline Chrm4 & -1.696 & A_52_P988817 & -2.460 \\
\hline Mrgprg & -1.699 & Heatr3 & -2.536 \\
\hline Tbl1x & -1.707 & Tmem89 & -2.553 \\
\hline Tsfm & -1.715 & B630019A10Rik & -2.663 \\
\hline Matk & -1.717 & Gpm6a & -2.704 \\
\hline Tssk5 & -1.718 & Gcn5l2 & -2.746 \\
\hline Prdm10 & -1.719 & Hnrpl & -2.973 \\
\hline Gm440 & -1.721 & Bcas1 & -2.983 \\
\hline Marcksl1 & -1.727 & 1700013F07Rik & -3.016 \\
\hline Plcb3 & -1.728 & A_52_P980948 & -4.047 \\
\hline
\end{tabular}




\section{Apêndice 2 - Lista dos genes de TRAs}

\begin{tabular}{|c|c|}
\hline \multicolumn{2}{|c|}{ Genes de antígenos restritos a tecidos } \\
\hline Adamtsl5 & Mpped1 \\
\hline Alpi & Mrgprg \\
\hline Arsi & Muc20 \\
\hline Asgr1 & Myl3 \\
\hline Bcas1 & Odf3 \\
\hline Bmp5 & Plcb3 \\
\hline Bpifa5 & Pnmt \\
\hline Cbln1 & Prss37 \\
\hline Cdh3 & Rrad \\
\hline Cib2 & Shc2 \\
\hline Clps & Sox15 \\
\hline Col4a3 & Spnb4 \\
\hline Crhr1 & Sult1c2 \\
\hline Cspg5 & Syt16 \\
\hline Cylc2 & Tmc1 \\
\hline Defb15 & Tmeff1 \\
\hline Dhrs11 & Tmem81 \\
\hline Dock6 & Tmem89 \\
\hline Dusp23 & Xcr1 \\
\hline Faim2 & Capn3 \\
\hline Fam122b & Duoxa1 \\
\hline Hrh3 & Expi \\
\hline Inhba & Fbrsl1 \\
\hline Lhb & Kena7 \\
\hline Lrrc46 & Lalba \\
\hline Man2b2 & Nxn12 \\
\hline Matk & Oas1f \\
\hline Mobp & $\mathrm{Pbp} 2$ \\
\hline Mpp2 & St3gal1 \\
\hline
\end{tabular}


Apêndice 3 - Ensaio de imunofluorescência de AIRE no tempo de $\mathbf{4 8}$ horas após a transfecção. Há uma redução no número de células mTEC 3.10 expressando Aire com o passar do tempo, tanto nas culturas controle quanto nas culturas transfectadas.

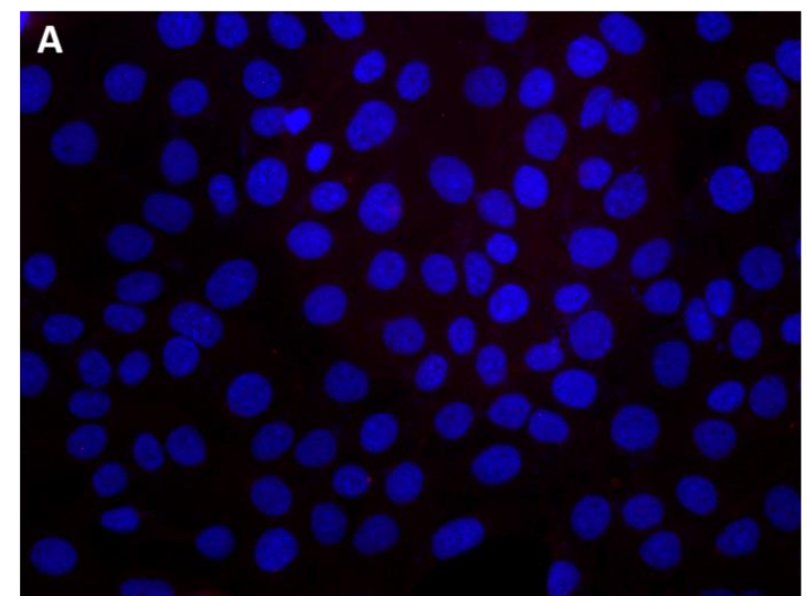


ANEXO 


\section{Anexo}

\section{Anexo 1. Certificação da comissão de ética em experimentação animal}
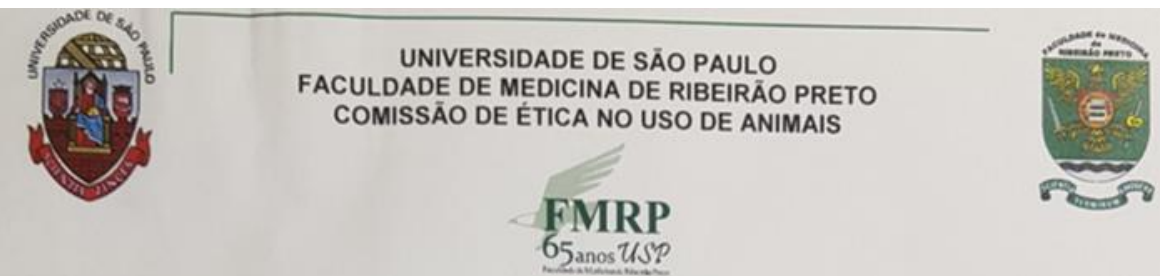

\section{CER TIFICADO}

Certificamos que o Protocolo intitulado "Efeito de mutações no gene AIRE (Sindrome APSI) induzidas por CRISPR-Ca9 na conformação da proteina, no transcriptoma de células mTEC e na sua interação com timócitos", registrado com o número 003/2017-1, sob a responsabilidade do Prof. Dr. Geraldo Aleixo da Silva Passos Junior, envolvendo a produção, manutenção ou utilização de animais pertencentes ao filo Chordata, subfilo Vertebrata (exceto humanos) para fins de pesquisa cientifica, encontra-se de acordo com os preceitos da Lei $\mathrm{n}^{\circ} 11.794$ de 8 de outubro de 2008, do Decreto $\mathrm{n}^{\circ} 6.899$ de 15 de julho de 2009 e com as normas editadas pelo Conselho Nacional de Controle de Experimentação Animal (CONCEA), e foi APROVADO pela Comissão de Ética no Uso de Animais da Faculdade de Medicina de Ribeirão Preto da Universidade de São Paulo em reunião de 26 de junho de 2017.

Este Protocolo prevê a utilização de 100 camundongos C57BL/6 fêmeas pesando $20 \mathrm{~g}$ e oriundos do Serviço de Biotério da Prefeitura do Campus de Ribeirão Preto da Universidade de São Paulo. Vigência da autorização: 26/06/2017 a 30/07/2022.

We certify that the Protocol $n^{\circ}$ 003/2017-1, entitled "Effect of AIRE gene mutations (APSI syndrome) induced by CRISPR-Cas 9 in protein conformation, transcriptome of $m T E C$ cells and its interaction with thymocytes". is in accordance with the Ethical Principles in Animal Research adopted by the National Council for the Control of Animal Experimentation (CONCEA) and was approved by the Local Animal Ethical Committee from Ribeirăo Preto Medical School of the University of Săo Paulo in 06/26/2017. This protocol involves the production, maintenance or use of animals from phylum Chordata, subphylum Vertebrata (except humans) for product House of Ribeiråo Preto Medical School, University of Sato Paulo. This certificate is valid until 07/30/2022.

Ribeirão Preto, 26 de junho de 2017

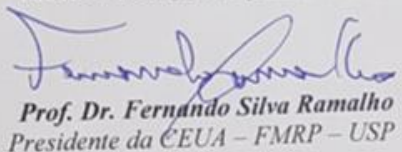

